\title{
DESENVOLVIMENTO VEGETATIVO E REPRODUTIVO DO PESSEGUEIRO EM POMAR COMPACTO SOB PODA DRÁSTICA ANUAL
}

\author{
WILSON BARBOSA \\ Biólogo
}

ORIENTADOR: PrOf. Dr. VLADIMIR RODRIGUES SAMPAIO

Disṣertação apresentạda à Escola Superior de Agricultura "Luiiz de Queiroz", da Universidade de São Paulo; para obtenção do título de Mestre em Agronomia. Área de Concentração: Fitotecnia.

\author{
P I R A C I C A B A \\ Estado de São Paulo - Brasil \\ maio - 1989
}


Barbosa, Wilson

B238d Desenvolvimento vegetativo e reprodutivo do pessegueiro em pomar compacto sob poda drástica anua1. Piracicaba, 1989.

$154 \mathrm{p}$. ilus.

Diss. (Mestre) - ESALQ

Bibliografia.

1. Pêssego-Crescimento. 2. Pêssego-Poda.

3: Pêssego-Reprodução. I. Escola Superior de Agricultura "Luiz de Queiroz", Piracicaba. 


\title{
DESENVOLVIMENTO VEGETATIVO E REPRODUTIVO DO PESSEGUEIRO EM POMAR COMPACTO SOB PODA DRÁSTICA ANUAL
}

\author{
Bio1. WILSON BARBOSA
}

Áprovada em: 04/AGOSTO/1989

Comissão Ju1gadora:

Prof. Dr. Vladimir Rodrigues Sampaio ESALQ/USP

PqC: Dr. Mārio Ojima IAC/CPA

Prof. Dr. Gerhard Bandel

ESALQ/USP

Prof. Dr. VLADIMIR RODPIGUES SAMPAIO

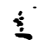
Orientador 
As duas pessoas que amo muito

- minha esposa Magali (27) e nosso filho Wilson Augusto (2) - com quem posso pensar em voz alta, dedico... 


\section{CARTA AOS JOVENS CIENTISTAS}

IVAN P. PAVLOV (1849-1936)

o que desejaria eu aos jovens de minha Pátria, consagrados à ciência?

Antes de tudo - constância. Nunca posso falar sem emoção. sobre essa importante condição para o trabalho cientifíco. Constância, constância e constância! Desde o início de seus trabalhos habituem-se a uma rigorosa constância na acumulação do conhecimento.

Aprendam $O A B C$ da Ciência antes de tentar galgar seu cume. Nunca acreditem no que se segue sem assimilar o que vem antes. Nunca tentem dissimular sua falta de conhecimento, ainda que com suposições e hipóteses audaciosas. Como se alegra nossa vista com o jogo de cores dessa bolha de sabão - no entanto ela, inevitavelmente, arrebenta e nada fica além da confusão.

Acostumem-se à discrição e à paciência. Aprendam o trabalho árduo da ciência. Estudem, comparem, acumulem fatos.

Ao contrário das asas perfeitas dos pássaros, ' a Ciência nunca conseguirá alçar vôo, nem sustentar-se no espaço. Fatos - essa é a atmosfera do cientista. Sem eles nunça poderemos voar. Sem eles nossa teoria não passa de um esforço vazio.

Porém, estudem, experimentem, observem, esforcem-se para não abandomar os fațos à superfície. Não se transformem em arquivistas de fatos. Tentem penetrar no mistério de sua origem e, com perseverança, procurem as leis que os governam.

Em segundo lugar - sejam modestos. Nunca pensem que sabem tudo. E não se tenham em alta conta; possam ter sempre a coragem de dizer: sou "ignorante". 
Não deixem que o orgulho os domine. Por causa dele poderão obstinar-se, quando for necessário concordar; por causa dele renunciarão ao conselho saudãvel e ao auxílio amigo; por causa dele perderão a medida da objetividade.

No grupo que me foi dado dirigir, todos formavam uma mesma atmosfera. Estávamos todos atrelados a uma ünica tarefa e cada um agia segundo sua capacidade e possibilidades. Dificilmente era possível distinguir você próprio do resto do grupo. Mas dessa nossa comunidade tirávamos proveito.

Em terceiro lugar - a paixão. Lembrem-se de que a Ciência exige que as pessoas se dediquem a ela durante a vida inteira. E se tivessem duas vidas, ainda assim não seria suficiente. A Ciência demanda dos indivíduos grande tensão e forte paixão.

Sejam apaixonados por sua ciência e por suas pesquisas.

Nossa Pátria abre um vasto horizonte para os cientistas e é preciso reconhecer - a ciência generosamente nos introduz na vida de nosso país. Prossigam com o máximo de generosidade!

o que dizer sobre a situação de nossos jovens cientistas? Eis que aqui tudo é claro. A vocês muito foi dado, mas de vocês muito se exige. E para os jovens, assim como para ñós, a questão de honra é ser digno de uma esperança maior, aquela que é depositada na ciência de nossá Pátria. 


\section{AGRADECIMENTOS}

A DEUS, "in lato sensu", ao possibilitar essa nossa "caminhada" pacífica e a realização deste trabalho de pesquisa.

Ao Prof.Dr. Vladimir Rodrigues Sampaio, pela orientação, apoio e amizade.

Aos colegas Fernando Antonio Campo Dall'Orto e Mário 0jima, por nossa formação em pesquisa e pelas valiosas criticas e sugestões ao trabalho.

Ao Fernando Picarelli Martins e José de Camargo Barros, da Estação Experimental de Jundiaí, pela facilidade e auxílio na execução da pesquisa.

Ao Instituto Agronômico de Campinas (IAC), à Escola Superior de Agricultura "Luiz de Queiroz". (ESALQ/USP), ao Conselho Nacional de Desenvolvimento Científico e Tecnológico ( $\mathrm{CNPq}$ ) e à Fundação de Amparo à Pesquisa do Estado de São Paulo (FAPESP), pelas importantes contribuições à nossa especialização cientifica e ao presente trabalho.

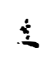

Aos colegas Orlando Rigitano, Toshio Igue, Neusa Diniz da Cruz, Onivaldo Camargo, Dagmar Vieira Gonçalves Leme e demais funcionários do IAC, pela colaboração ao trabalho.

Aos meus familiares: pais - Luiz Barbosa, "in memorian" e Santina Inês Miranda Barbosa; irmãos - Laura, Malvina, Moacir, Luiz e Eneida, e demais pessoas que, direta ou indiretamente, auxiliaram para que este trabalho fosse realizado. 


\section{SUMÂRIO}

Pāgina

LISTA DE FIGURAS

$\mathrm{XI}$

XIV

LISTA DE TABELAS $\ldots \ldots \ldots \ldots \ldots \ldots \ldots \ldots \ldots \ldots$

CURRICULUM VITAE

XVI

RESUMO

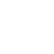

.

SUMMARY

1. INTRODUÇÃO $\cdots$

2. REVISÃO DE LITERATURA

2.1. Generalidades sobre o pessegueiro ........ 2.1.1. Origem, classificação botânica e

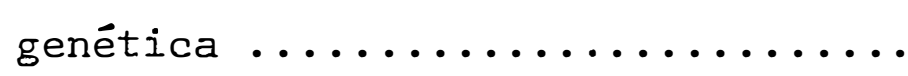

- 2.1.2. Características morfológicas....... 2.1.3. Características culturais ........

2.2. Desenvolvimento vegetativo do pessegueiro. 16 2.2.1. 0 embrião e a plântula ..........

2.2.2. Juvenilidade e maturidade das plan-

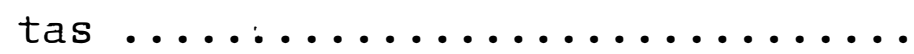


2.3. Desenvolvimento reprodutivo do pesseguei-

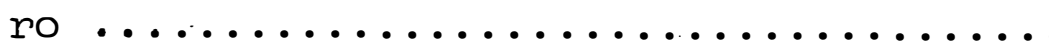

2.3.1. A indução floral ............. 31

2.3.2. A iniciação floral ........... 33

2.3.3. Desenvolvimento floral e maturação

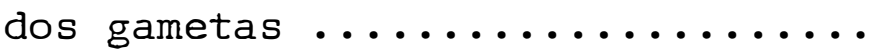

2.3.3.1. Formação do saco polínico e dos grãos de pólen ....

2.3.3.2. A formação dos óvulos. e do aparelho carpelar ....

2.3.4. Floração, polinização e fertilização .................... 41

2.3.5. Frutificação .............. 44

2.4. Desenvolvimento do pessegueiro no sistema de pomar compacto ............... 50 2.4.1. A fitotecnia e a ecofisiologia ...

3.2. Localização e ecologia de ārea experimental 
Página

3.3. Procedimento Experimental ........... 63

3.3.1. Germinação das sementes e formação dọs porta-enxertos ........ 63

3.3.2. Plantio dos porta-enxertos, enxertia e tratos culturais ...... 64

3.3.3. Podas drásticas ............. 65

3.3.4. Desenvolvimento vegetativo ..... 66

3.3.4.1. Coleta e preparo histo-

Iógico das gemas ...... 66

3.3.4.2. Cultura in vitro de meristema.$\ldots \ldots \ldots \ldots$

3.3.4.3. Quebra-de-endodormência das gemas, floração e palinologia ......... 72

3.3.4.4. Frutificação, ciclo de crescimento dos frutos e produção ...........

3.3.4.5. Anālise Estatística ...

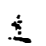

4. RESULTADOS E DISCUSSÃO

4.1. Desenvolvimento vegetativo e reprodutivo dos pessegueiros 'Tropical' e 'Auro-

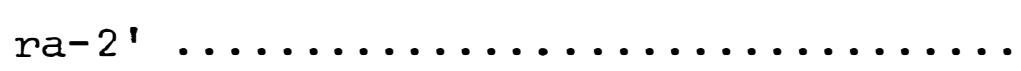

4.1.1. Comportamento vegetativo ....... 
4.1.2. Diferenciação floral ...........

4.1.2.1. Histologia, crescimento e desenvolvimento meristemático dos pessegueiros controles ............

4.1.2.2. Histologia meristemātica dos pessegueiros sob poda drástica ...............

4.1.3. Quantidade de nós e de gemas nos ramos $\ldots \ldots \ldots \ldots \ldots \ldots \ldots \ldots$

4.1.4. Desenvolvimento de gemas vegetativas e floriferas .............. 101

4.1.5. Floração e Palinologia .......... 105

4.1.6. Frutificação .............. 113

4.1.6.1. Frutificação efetiva .... 113

4.1.6.2. Crescimento dos frutos de 'Tropical' .............

4.1.6.3. Produção das plantas ....

5. CONCLUSÖES ....................... 


\section{LISTA DE FIGURAS}

Página

1. Desenho esquemático mostrando os níveis endógenos de hormônios promotores de inibidores de crescimento, bem como da respiração, de acordo com o termoperíodo estacional .............

2. Esquema de um nó de gema de pessegueiro ......

3. Histograma do índice médio de crescimento dos ramos dos pessegueiros 'Tropical' e 'Aurora-2', em três meses subsequentes às podas drásticas ....

4. Fotoperíodo calculado em função do número de horas de brilho solar e das intensidades luminosas superiores ou iguais a 10 "foot-candle" $(j 07,6$ iux $) \ldots \ldots \ldots \ldots \ldots \ldots \ldots \ldots \ldots \ldots . . \ldots \ldots \ldots$

5. Valores mensais de temperatura média e precipitação pluviométrica, régistrados na Estação

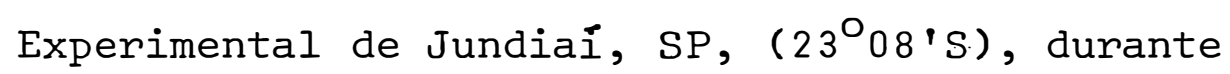
o período de desenvolvimento dos pessegueiros 'Tropical' e 'Aurora-2', em pomar compacto, sob

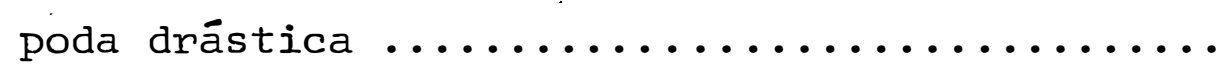


Página

6. Estâdios da morfogênese floral do pessegueiro,

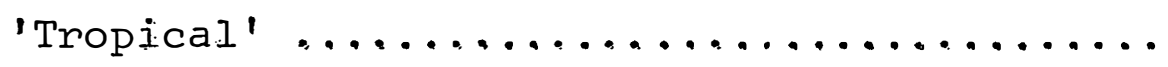

7. Epoca de iniciação floral dos pessegueiros 'Tropical' e 'Aurora-2', com base no Controle e podas drásticas de 30 de setembro, 30 de outubro e 30 de novembro de $1986 \ldots \ldots \ldots \ldots$

8. Relação entre o tamanho das gemas e os estádios de morfogênese floral no pessegueiro 'Tropical', com base no Controle e épocas de

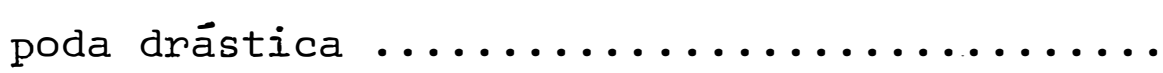

9. Histograma do número médio de nós por centímetro de ramo dos pessegueiros 'Tropical' e 'Aurora-2', em pomar compacto, sob poda drás-

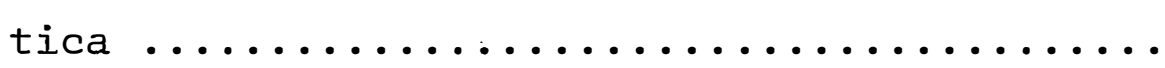

10. Histograma do número médio de gemas por nó de ramo dos pessegueiros 'Tropical' e 'Aurora-2', eñ pomar compacto, sob poda drástica ........

11. Número médio de gemas floríferas e vegetativas por centímetro de ramo dos pessegueiros 'Tropical' e 'Aurora-2', em pomar compacto, sob poda drástica $\ldots \ldots \ldots \ldots \ldots \ldots \ldots \ldots$ 
Página

12. Hịstograma da porcentagem de gemas florîferas e vegetativas dos pessegueiros 'Tropical' e 'Aurora-2', em pomar compacto, sob poda drástica $\ldots \ldots \ldots \ldots \ldots \ldots \ldots \ldots \ldots \ldots \ldots \ldots$

13. Histograma do número médio de grãos de pólen por flor dos pessegueiros 'Tropical' e 'Aurora-2', em pomar compacto, sob poda drástica.

14. Crescimento dos frutos do pessegueiro 'Tropical', conduzido no sistema de pomar compacto.

15. Pictograma da maturação dos frutos dos pessegueiros 'Tropical' e 'Aurora-2', em pomar compacto, com base no Controle e nas épocas

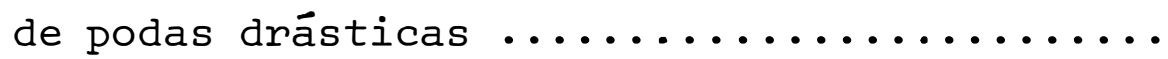




\section{LISTTA DE TABELAS}

Página

1. Características dos frutos de 20 principais cultivares de pêssegos e nectarinas, lançados pelo Instituto Agronômico de Campinas (IAC) .

2. Nümero de pessegueiros por hectare em 256 diferentes combinações de espaçamentos, sob linha simples $\ldots \ldots \ldots \ldots \ldots \ldots \ldots \ldots \ldots \ldots$

3. Altura média dos ramos dos pessegueiros 'Tropical' e 'Aurora-2', conduzidos em pomar compacto, sob diversas épocas de poda drástica.

4. Número médio de nôs de gemas por metro de ramo dos pessegueiros 'Tropical' 'Aurora-2', conduzidos em pomar compacto, sob diversas

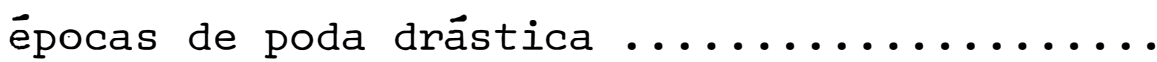

5. Médias e os respectivos intervalos de confiança (LI, limite inferior e LS, limite superior), para $\circ$ número de antera por flor e pólen por antera do pessegueiro 'Tropical', cultivado em pomar

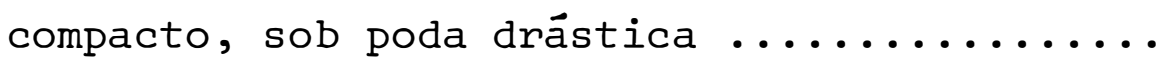


6. Mêdias e os respectivos limites de confiança. (LI, limite inferior e LS, limite superior), para o número de anteras por flor e grãos de pólen por antera do pessegueiro 'Aurora-2', em pomar compacto, sob poda drástica ........

7. Porcentagem de germinação in vitro dos grãos de pólen dos pessegueiros 'Tropical' è 'Aurora-2', em pomar compacto, sob poda drás-

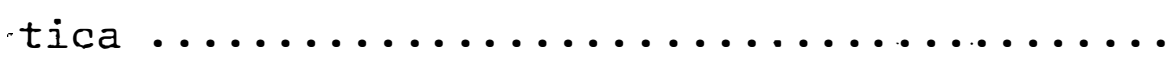

8. Porcentagem de frutificação efetiva dos pessegueiros 'Tropical' e 'Aurora-2', em pomar

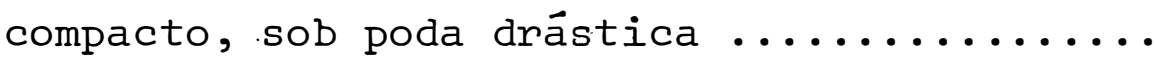

9. Número de frutos por metro de ramo dos pessegueiros 'Tropical' e 'Aurora'2', em pomar

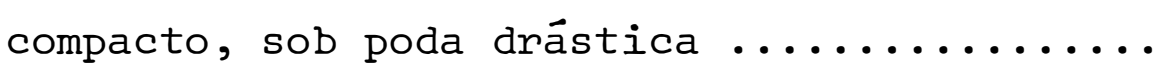

10. Produção dos pessegueiros 'Tropical' e 'Auróna-2', ém pomar compacto, sob poda drástica. 


\section{"CURRICULUM VITAE"}

WILSON BARBOSA, nascido em ārea rural de Limeira, São Paulo, em.30/09/1957, cresceu em meio a natureza, junto às lavouras da família. Estudou na Escola. de 10 e $20^{\circ}$ graus Nossa Senhora das Dores, em Artur Nogueira, SP. Admirador das Ciências Biolọgicas, foi acadêmico de Biologia na Pontifícia Universidade Católica de Campinas, de 1978 a 1981. Ao graduar=se iniciou seus trabalhos de pesquisas, na "Seção de Fruticultura de Clima Temperado, do Instituto Agronômico (IAC). Foi contemplado de início com Bolsa de Aperfeiçoamento da FAPESP e depois com a de Pesquisa do CNPq, com o Projeto: Melhoramento genético e cultural de frutiferas de clima temperado: pessegueiro, nectarineira e ameixeira... De 1984 a 1987 foi contratado como pesquisador-executor do Projeto: Desenvolvimento do cultivo de pêssegos precoces em são Paulo, pelo convênio: SAA-IAC-FIPEC. Em 12/10/1988, ingressou no IAC, por concurso, no cargo de Pesquisador Científico I, para realizar pesquisas de melhoramento genético e cultural com o pesșegueiro, ameixeira, nectarineira, macieira, pereira, marmeiteiro, caquizeiro, nespereira, figueira, nogueira-macadâmia e outras. Desenvolve trabalhos básicos de: cultura in vitro de embriões, micropropagação, ecofisiologia, histologia, palinologia, citogenética, pomologia e propagação seminifera e vegetativa. Participou do lançamento de cultivares de superior qualidade organoléptica e adaptados às condições ecológicas paulistas. Publicou cerca de 60 trabalhos técnico-cientificos, abrangendo os tópicos bio-agrônômicos da fruticultura temperada. 
XVII.

\section{DESENVOLVIMENTO VEGETATIVO E REPRODUTIVO DO PESSEGUEIRO EM POMAR COMPACTO SOB PODA DRÁSTICA ANUAL}

Autor: WILSON BARBOSA

Orientador: Prof. Dr. VIADIMIR RODRIGUES SAMPAIO

\section{RESUMO}

Pesquisou-se o desenvolvimento vegetativo e reprodutivo dos pessegueiros (Prunus persica. L. Batsch) do IAC: 'Tropical' e 'Aurora-2', no sistema de pomar compacto (espaçamento: 3×2m - 1.667 plantas/ha), sob poda drástica anual de renovação de copa.

Os pessegueiros foram podados em: 30 de setembro, 30 de outubro e 30 de novembro de 1986. Os seguintes parămetros bio-agronômicos foram analisados: crescimento dos brotos e ramos; porte das plantas; quantidade de nós e de gemas vegetatívas e floríferas; intensidade de floração' en frutificação; palinologia; ciclo de crescimento e época de maturação dos frutos e produção. A sistemática da indução, diferenciação e desenvolvimento floral, correlacio- 
nada às épocas de poda, foi também investigada. 0 experimento foi conduzido na Estação Experimental de Jundiaí $\left(23^{\circ} 08^{\prime} \mathrm{S}\right)$, do Instituto Agronômico, Campinas, São Paulo.

Os melhores resultados foram obtidos com 0 cultivar Tropical, especialmente podado em 30 de setembro. As plantas sob este tratamento se desenvolveram adequadamente, obtendo ao final do ciclo vegetativo $\bar{x}=2,40$ metros de altura; $\bar{x}=44,3$ nós por metro de ramo (m.r.) e 2,46 gemas por nó. Através de cortes histológicos dos meristemas observou-se que a sua indução floral deve ter ocorrido em janeiro. A organogênese floral das gemas processou-se, porēm, em fevereiro e a floração em início de julho; cerca de $76 \%$ das gemas diferenciaram-se em botões florais. As flores, em número médio de $83 / \mathrm{m} . \mathrm{r}$., apresentaram $\bar{x}=44,3$ anteras; o número de grãos de pólen por antera e flör foi $\bar{x}=1.706$ e 75.044, respectivamente, com uma germinação in vitro de $\bar{x}=85,3 \%$. A frutificação efetiva foi da ordem de $30 \%$, com $\bar{x}=25$ frutos $/ \mathrm{m} \cdot \mathrm{r}$. A produção das plantas atingiu $\bar{x}=8,26 \mathrm{~kg}$. 0 ciclo da florada a maturação dos frutos foi $\bar{x}=83$ dias. A floração ocorreu ao nono e a maturação dos frutos ao 12 : mês após a poda drástica. As plantas de 'Tropical', podadas em $30 / 10$ e $30 / 11$, apresentaram indices inferiores em todos os parâmetros fenológicos avaliados.

O cultivar Aurora-2, de ciclo mediano dias da florada à maturação dos frutos), não se comportou 
adequadamente ao sistema de poda drástica pós-colheita.

Os dados comprovaram que no sistema de pomar compacto com poda drástica anual, os cultivares devem apresentar maturação bem precoce, cuja sáfra ocorra em setembro, e, no máximo em outubro, sucedendo-se a poda. 0 pessegueiro, podado cedo, recupera uma nova copa, sadia e fisiologicamente matura ao ciclo seguinte. Esta metodologia è adequada a regiões de clima subtropical-tropical; nessas condições, o desenvolvimento vegetativo e reprodutivo do. pessegueiro atinge intensidade e precocidade maiores. 
$\mathrm{XX}$.

\title{
VEGETATIVE AND REPRODUCTIVE DEVELOPMENT OF PEACH UNDER THE MEADOW ORCHARD SYSTEM WITH DRASTIC PRUNING
}

\author{
Author: WILSON BARBOSA \\ Advisor: Prof. Dr. VLADIMIR RODRIGUES SAMPAIO
}

\section{SUMMARY}

This paper relates the vegetative

and reproductive development of 'Tropical' and 'Aurora-2' peach seletions from IAC, under the meadow orchard system, with annual drastic pruning.

The peach trees"were pruned in: 1986, september, 30 , october, 30 and november, 30 . The following parameters were analyzed: shoot and branches growth; tree size, nodes and buds vègetative and flower-buds quantity; flowering and fruit set intensity; palinology; yield, cycle and fruit maturity season. The floral induction, differentiation and development"systematic, in relation to the pruning season, was investigated. The experimental plot was located at the Estação Experimental of Jundiai ( $\left.23^{\circ} 08^{\prime} \mathrm{S}\right)$ of the Instituto 
Agronômịco, Campịnas, Brazil.

The best result was obtained with the 'Tropical', especially pruned in september, 30. This treatment, the peach trees grown adequately, and at the end of vegetative cycle, its measured $\bar{x}=2.40$ meters. The number of node per branch meter (b.m.) was $\bar{x}=44.3$ and buds per node $\bar{x}=2.46$. Through histological longitudinal cross were observed which its floral induction may be occured in january. The floral buds organogenesis was begun in february and the flowering in early july; about $76 \%$ of buds differentiated flowers. The number of flower/b.m. was $\bar{x}=83.0$; its individually, present $\bar{x}=44.3$ anthers. The number of pollen per anther and flower was $\bar{x}=1,706$ and 75,044 , respectively, with an in vitro germination $\bar{x}=85.3 \%$. The fruit set was aproximately $30 \%$, with 25 fruit/b.m. The fruits production per tree was $\bar{x}=8.26 \mathrm{~kg}$. The average cycle from full bloom to the fruits ripen was $\bar{x}=83$ days. The flowering in this treatment occured at $9^{\text {th }}$ and fruits ripen in $12^{\text {th }}$ month after pruning. The 'Tropical' peach trees, pruned in october, 30 and november, 30 , presented worst - performance to the several phenological parameters evaluated.

The 'Aurora-2' peach, with fruit ripen approximately 120 days from bloom, didn't present adequately behavior in the meadow orchard system, under drastic pruning. The results showed that in the meadow orchard 
system, with drastic pruning, the cultivars need to be early maturity, such harvest occurs in semptember or in early october, to make the drastic pruning The peach tree, early pruned, recuperates a mature new canopy and healthy to the next cycle. This present metodology is appropriate to the subtropical-tropical climates; in this environmental conditions, the vegetative and reproductive development peach tree reaches highest intensity and precocity. 


\section{INTRODUÇÃO}

O pessegueiro, apesar de considerado espécie típica de clima temperado, é hoje cultivado nas mais variadas condições climáticas. Encontram-se plantios em regiões : de inverno desde bem rigoroso, até em outras praticamente desprovidas de frio hibernal. Essa adaptabilidade do pessegueiro, face aos diferentes tipos de clima, deve-se basicamente à seleção genética de cultivares tanto de alta, como de baixa exigência de frio. Dessa maneira, o pessegueiro se adapta em zonas distintas do globo, representadas por clima temperado e mesmo subtropical-tropical.

Em São Paulo, o pessegueiro é explorado em locais de pouco frio disponivel, nas āreas mais frescas das encostas serranas, e em outras de clima subtropical a tropical, do interior do Estado. o cultivo econômico em regiões paulistas consideradas não tradicionais à cultura, deve-se ao emprego de materiais melhorados, principalmente pelo InstituAgronômico de Campinas, a partir da década de 60, quando fóram disponibilizados cultivares especialmente aclimatados às condições de inverno ameno.

O início da safra paulista de pêssegos ocorre, 
ẹm geral, em época bastante antecipada em relação à dos demaís Estados do Sul. Essa precocidade de maturação é decorrente do clima, da utilização de cultivares prôprios e do emprego de técnicas subsidiārias especiais de cultivo. Os cultivares adotados em são Paulo estendem, normalmente, suas safras de setembro a fevereiro, disponibilizando morcado uma série de diferentes pêssegos e nectarinas. Seus frutos são de polpa branca ou amarela, de caroço preso ou solto, de sabor doce ou mais acidulado, "e de epiderme esverdeadocreme à coloração vermelho-intensa.

Hoje, em São Paulo cultiva-se cerca de duas dezenas de cultivares de pêssegos, de excelente qualidade organoléptica, altamente produtivos e dotados de rázoável adaptabilidade climática. A produção persícola paulista, incluindo as nectarinas, está estimada em 15 mil toneladas, proveniètes de cerca de 500 mil árvores em fase produtiva. Dessas, $80 \%$ constituem-se de pêssegos para consumo ao natural, e os $20 \%$ restantes, para industrialização. No Brạsil, a maior produção persícola é encoṇtrada no Rio Grande do Sul, onde se concentra $60 \%$ da safra nacional; em sua maior parte, destinada ao aproveitamento industrial, pelos tipos predominantes de conserva. 0 consumo nacional de pêssego está estimado em apenas 200 gramas por pessoa, por ano.

0 pessegueiro, nas condições paulistas de temperaturas hibernais mais quentes, permite a realização de pesquisas fitotêcnicas especiais, a exemplo da ultra-alta densi- 
dade de plantio, com poda drástica pös-colheita. Esse sistema de cultịvo, recêm introduzido na persicultura paulista; vem aos poucos obtendo reconhecimento dos fruticultores mais progressistas. No entanto, comó prática cultural nova necessita de pesquisas complementares visando seu aperfeiçoamento; dentre essas, as prioritārias acham-se ligadas às āreas de fitotecnia, melhoramento genético e ecofisiologia. No que tange a fitotecnia, merecem especial atenção, as pesquisas sobre época de poda drástica é de espaçamento. Na área de melhoramento genético devem ser pesquisados os genótipos ultra-precoces e rústicos. Na ecofisiologia, há carência de pesquisas sobre a sistemática vegetativa, diferenciação floral, endodormência, floração e frutificação.

$\mathrm{Na}$ literatura são escassas as pesquisas que englobam os aspectos ontogenéticos, ecofisiológicos e fitotécnicos de pessegueiros em alta densidade de plantio.

A presente dissertação relata o desenvolvimento vegetativo e reprodutivo de dois novos pêssegos IAC: 'Tropical' e 'Aurora-2', cultivados em pomar compacto, sob podạ drástịca anual de renovação de copa. 


\section{REVISÃO DE LITERATURA}

\subsection{Generalidades sobre o pessegueiro}

2.1.1. Origem, classificação botânica e genētica

Apesar da derivação do nome, hã indicações de que o pessegueiro Prunus persica (L.) Batsch seja uma espécie nativa da China, "onde há mais de três milênios já se faziam referências à sua existência. Acredita-se que da China foi levado à Pérsia, sendo daí distribuído em toda a Europa (HEDRICK, 1916).

Foi introduzido na América do Norte pelos espanhóis, no início do século XVI, e no Brasil, mais propriamente, em São Vicente, a partir de 1532, pela expedição colonizadora de Martin Afonso de Souza (GOULD, 1923; RIGITANO, 1945; SACHS, 1984). A introdução primeira provavelmente teS.

nha sido feita com plantas trazidas da Ilha dos Açores ou da Madeira.

Os pessegueiros cultivados pertencem à família Rosaceae, à subfamília Prunoideae, ao genêro Prunus, ao subgenêro Amygdalus a à espécie Prunus persica. Há refe- 
rências ainda de outras espécies não cultivadas, a saber: davidiana, mira, ferghanensis e kansuensis, origināriqg da Ásia Ocidental (China), , andersonii e fasciculata dá América do Norte (GOULD, 1923; RIGITANO, 1945).

À espécie Prunus persica (L.) Batsch são ainda consideradas três variedades botânicas:

1. vulgaris: abrange os pessegueiros cultivados, tanto para o consumo ao natural ou em conserva, derivados de tipos originários da Pérsia e do Oeste Europeu (frütos grandes, carnosos e suculentos, com polpa amarela e caroço solto), do Norte da China (frutos carnosos e firmes, com polpa amarela e caroço preso) e do Sul da China (frutos doces e suculentos, com polpa branca e baixa exigência de frio hibernal).

2. nucipersica: compreende as nectarinas (os pêsşegos: 'sem pelos-fator genético simples e recessivo). Podem apresentar, epiderme avermelhada. ou : creme-esverdeada, polpa amarela ou branca e caroço preso ou solto.

3. platycarpa: são variedades de pessegueiros que produzem frutos achatadós no sentido da base para o ápice (fator genëtico simples e dominante). São do tipo "Peen-to", originários da China, podendo apresentar polpa tanto amarela como branca e epiderme pilosa ou glabra. Adaptam-se a clima ameno e são cultivados comercialmente em pequena escala (HEDRICK, 1916; GOULD, 1923 e SACHS, 1984). 
Essas três variedades botânicas de Prunus persica, possuem o mesmo número cromossômico básico $\mathrm{n}=8$, e somático $2 n=16$. Apresentam as características comuns de compatibilidade de enxertia e polínica. Genes com dominância simples são responsáveis pelos seguintes fatores: caroço solto, polpa branca, acidez, época de maturação e pubescência dos frutos (MONET, 1983; OJIMA et al., 1983).

0 coeficiente de herdabilidade do pessegueiro, ligado aos principais caracteres de interesse técnico ou econômico, são respectivamente: 0,16 à juvenilidade, 0,39 à data da floração; 0,84 à época de maturação; 0,08 à produtividade; 0,31 ao tamanho; 0,13 à firmeza, 0,19 à acidez e 0,01 aos sólidos solúveis do fruto (HANSCHE et al., 1972; HANSCHE, 1986a; 1986b).

\subsubsection{Características morfológicas}

…un pessegueiro, quando deixado a se desenvolver naturalmente, pode atingir " seis metros de altura e sobreviver por 50-60 anos, dependendo do material e das éndições climatoedáficas. Possui, nestas condições, um tronco principal com diâmetro ao redor de $40 \mathrm{~cm}$, de onde se originam ramos bem vigoroșos, em número de quatro a cinco, e que se afinam à. medida que atingem a extremidade da copa.

De acordo com a distribuição das gemas de flor, os ramos produtivos são classificados em mistos, brindilas, dardos e "ladrões". Os ramos mistos, os mais fre- 
quentes, possuem comprimento variável, entre cinco e cem centímetros; são portadores de gemas de flor e vegetativas, terminando geralmente em um do último tipo. Nas brindilás, ramos finos e flexíveis, menores de $30 \mathrm{~cm}$ de comprimento, podem prevalecer gemas de flor. Seu ápice pode conter tanto uma gema florífera como uma vegetativa. Os dardos, ramos menores, com cinco centímetros de comprimento, apresentam gema apical vegetativa e numerosas gemas floríferas. Os "ladrões", ramos vigor,osos, em geral, não üteis à produção, se originam da base da planta ou de seu tronco e crescem em posição vertical; podem apresentar ramificação secundāria, sempre com gemas vegetativas.

0 seu sistema radicular é de início pivotante, e quando adultos, com distribuição lateral de numerosas raízes pouco profundas, explorando área aproximada à projeção da copa. O seu rïtmo de crescimento acompanha normalmente o da parte aérea, atingindo uma intensidade máxima no início do outono.

As folhas, que se apresentam de duas a quatro por nó ou gema, são do tipo completas, oblongas, lanceoladas ou peninérveas, dotadas de pecíolos curtos. Átingem de quatro a cinco centímetros de largura, por 14 a $18 \mathrm{~cm}$ de comprimento. Apresentam bordas serriadas, crenadas ou di- gitadas e de coloração verde-escura durante a fase vegetativa e amarelo-esverdeada no outono. Na base da lâmina foliar ou em seu pecíolo estão presentes uma ou mais glândulas 
(nectários), que podem ser reniformes ou circulares. $\grave{A}$ essas glândulas, quando ausentes, correlaciona-se uma suscetibilidade ao oídeo. Para proteção dos primórdios foliares, as gemas apresentam em média sete escamas de coloraçao castanha.

As-flores são perfeitas, completas;' '. períginas e normalmente monopistiladas. Diferenciam-se no início do verão, atravēs de alterações dos processos bioquímicos, que condieionam de modo irreversível a morfologia dos meristemas das gemas vegetativas. Podem exibir duas formas: rosácea, de pétalas grandes, bem abertas e de coloração róseo-clara; e, : eampanulada, de pétalas ...... pequenas, pouco atraentes e de coloração róseo-escura. São em geral auto-férteis, à exceção de alguns poucos cultivares. Apresentam cinco sépalas, đìneo:pétalas e 30 anteras, dependendo do material, de coloração amarela e às vezes um pouco avermelhadas. 0 ovário nos pêssegos é pubescente e nas nectarinas é glabro", possuindo dois óvulos anātropos, 'sendo que um deles é abortivo.

o fruto é do tipo drupa-carnoso típico, com fino pericarpo, mesocarpo carnoso e suculento (polpa) e endocarpo lenhoso (caroço). Em geral apresenta o formato esférico, podendo variar entre os seguintes: oblongo, elíptico, ovalado, arredondado, e às vezes, com o ápice saliente. A coloração de sua epiderme, quando madura, pode apresentar as seguintes tonalidades: verde, creme ou amarela; de matiz 
rósea, vermelha ou vinho, variando de 0 até quase $100 \%$ com relação a superfície total do fruto. A polpa pode se apresentar branca, creme, laranja, amarela e inclusive avermelhada. 0 endocarpo (caroço), de formato comumente ovoidal, pode ser preso, meio preso ou solto, apresentando em seu interior uma..amêndoa dicotiledônea e do mesmo ' formato de seu invólucro; alguns cultivares apresentam duas amênduas em cerca de $20 \%$ dos caroços. O sabor da polpa pode apresentar graduações na faixa de doce-acidulado-forte. ao simplesmente doce, com niveis de $\mathrm{pH}$ e ${ }^{\circ} \mathrm{Brix}$ de: 3,5 a 5,0 e de 8,0 a 18,0, respectivamente. Na TABELA 1 são apresentadas as principais características pomológicas. e organolépti-m cas dos diferentes cultivares de pêssegos e nectarinas obtidos no Instituto Agronômico de Campinas (IAC).

0 pêssego além de ser fruta extraordinàiamente atraente e saborosa, possui um ótimo valor nutritivo. Pode ser consumido tanto ao natural como industrializado, em càlda, geléias, iogurtes, bebidas, sucos e pessegadas. Quando maduro apresenta, em : média, em 100 gramas de polpa, as seguintes quantidades de nutrientes: 0,80g de . proteínas, $0,20 \mathrm{~g}$ de gorduras, 13,30g de carboidratos, 12,0mg de cálcio, 26,0mg de fósforo, 2,10mg de ferro, 5,0mg de vitamina A, $0,03 \mathrm{mg}$ de vitamina $\mathrm{B}_{1}$, 0,06mg de vitamina $\mathrm{B}_{2}, 28,0 \mathrm{mg}$ de vitamina C e 58,20 calorias (HEDRICK, 1916; GOULD, 1923; RIGITANO, 1945; JANICK 1968; JOLY, 1979; RIO GRĀFICA EDITORA, 


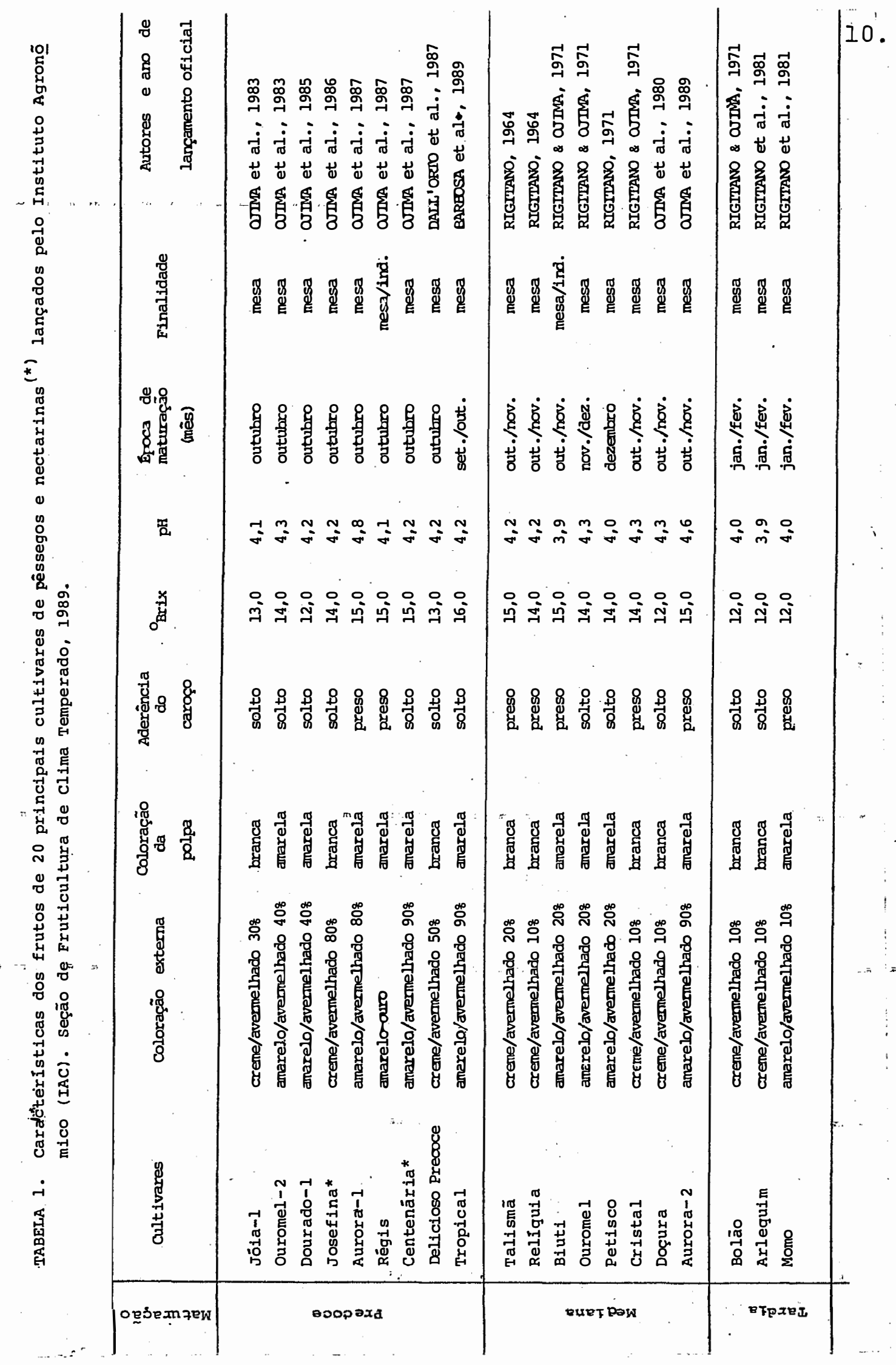


1980; TOMBOLATO, $1981^{(1)}$; MONET, 1983; SACHS, 1984; ESAU, 1986; BARBOSA et al. 1986e; 1989c).

\subsubsection{Características culturais}

o pessegueiro, a exemplo dos Prunus em geral, necessita de calor e luz abundantes para desenvolver.... suas" fôthas e amadurecer seus frutos na primavera e no verão, e certa quantidade de frio para que a planta entre em repouso durante o final do outono ou inverno. Situação vantajosa é caracterizada quando as chuvas caem com regularidade nas épocas críticas, durante a floração e frutificação, de modo que, nos meses mais quentes', a atmosfera permaneça rela-" tivamente seca. Nessas condições, as moléstias criptogâmicas são mais facilmente controláveis por meio de pulverizações fitossanitárías." Comon essas condições ideais "normalmente não ocorrem, é comum lançar-se mão da prática de irrigações. As geadas, os ventos frios e as chuvas abundantes, no início da brotação, podem prejudicar ou mesmo danificar a floração, a frutificação e o próprio desenvolvimento dos ramos. Suas raízes prosperam bem em diversos tipos de solos, mas prefèrencialmente em solos profundos (próximo de 1,0 metro de profundidade), permeáveis e bem

${ }^{l}$ ) TOMBOLATO, A.F.C. : Structure du bourgeon vegetatif -.. la formation de le feuilie chez le pêcher. Universidade de Bordeaux, II 1981. 56p. Relatório de estágio. Bordeaux. (não publicado) 
drenados. $0 \mathrm{pH}$ do solo mais favorável à franca vegetação, está entre 6,0 e 6,5, porém uma faixa pouco mais ampla pode ser suportável. A presença de matéria orgânica no solo é também benéfica, pois contribui à maior disponibilidade de nutrientes, melhora a estrutura e aumenta a infiltração da água (RIGITANO, 1945).

E propagado normalmente pela enxertia do tipo borbulhia, das variedades-copa desejáveis sobre porta-enxertos, obtidos de sementes, com ênfase aos cultivares resistentes aos nematöides do gênero Meloidogyne. Na persicultura de São Paulo emprega-se o cv. 'Okinawa', ou ainda eventualmente, outros porta-enxertos de sementes, disponiveis em pomares comerciais, constituídos de pêssegos de conserva ou de mesa.

0 pessegueiro é particularmente exigente de nitrogênio. Este nutriente estimula uma produção maior de ramos, de folhas verdes mais sadias e de gemas frutíferas, além de melhorar o tamanho individual dos frutos e outros aspectos culturais; quando em excesso pode prejudiẹar a planta. 0 nitrogênio não é translocado lateralmente, o que indica a necessidade de sua aplicação por toda a superfície do terreno. - Esta drupacia sob certas condições, responde muito bem à adição de potássio, cálcio, magnésio, fósforo, zinco, ferro, boro, manganês, cobre e enxofre, pela ordem de importância; o potássio é o segundo elemento, em exigência para o pessegueiro. Sintomas de defi- 
ciência de $K$ são comumente encontrados em solos leves, geralmente duas semanạs antes da colheita; responde às adubações dentro de duas semanas após a aplicação. 0 crescimento excessivo da planta na fase de produção dos frutos não é considerado benéfico. Pode ser sintoma de desequilíbrio do balanço nitrogênio-carbono; afeta” , a quantidade da produção, atrasa a maturação e favorece os riscos de prejuízos por doenças fúngicas; $\jmath^{-}$acarreta, em decorrência, o aumento dos trabalhos de poda. O diagnóstico da deficiência severa de um elemento mineral, em particular, pode ser obtido através de um detalhado exame dos sintomas (PIZA JUNIOR \& BRAGA, 1970; WESTEWOOD, 1978, MAGNANI et al., 1984).

A necessidade de calagem e adubação para pessegueiros cultivados no Estado de São Paulo é a seguinte: calcário, que é aplicado para elevar a saturação em bases a $70 \%$, se inferior a $60 \%$; tal corretivo normalmente é espalhado por todo o terreno, antes do plantio ou mesmo durante a exploração do pomar. No plantio, a necessidade de adubação por cova, corresponde a $2 \mathrm{~kg}$ de esterco de curral, bem curtịįdo, $1 \mathrm{~kg}$ de calcário magnesiano, $160 \mathrm{~g}$ de $\mathrm{P}_{2} \mathrm{O}_{5}$ e $60 \mathrm{~g}$. de $\mathrm{K}_{2} \mathrm{O}$; aplica-se com antecedência de, pelo menos, 30 dias do plantio. Na fase de brotação das mudas, são aplicados . em cobertura, ao redor desta, $60 \mathrm{~g}$ de $\mathrm{N}$, em quatro parcelas de 15g,: de dois em dois meses. No pomar em formação são aplicados de 60 a $120 \mathrm{~g}$ por ano de idade dos seguintes nutrientes: $\mathrm{N}, \mathrm{P}_{2} \mathrm{O}_{5}$ e $\mathrm{K}_{2} \mathrm{O}$, sendo que $\mathrm{O}$ em quatro parcelas de dois em 
dois meses. No pomar adulto, em produção, são aplicados por planta, cerca de $10 \mathrm{~kg}$ de esterco de galinha, ou cinco a dez vezes mais de esterco de curral bem curtido; 400 a $600 \mathrm{~g}$ de $\mathrm{N}, 200$ a $400 \mathrm{~g}$ de $\mathrm{P}_{2} \mathrm{O}_{5}$ e 240 a $480 \mathrm{~g}$ de $\mathrm{K}_{2} \mathrm{O}$ (CAMPINAS, 1987).

'A sua época de plantio mais adequada.vai desde o princípio do inverno, a partir dos meses de abril-maio atē agosto-setembro, com mudas de raízes nuas, pelo fato do pessegueiro ser uma planta de folhas caducas; necessita ser transplantado durante o seu período de hibernação, quando as seivas apresentam menor circulação no interior de seu sistema vascular. Pode ainda ser plantado de outubro a fevereiro, de preferência as mudas com torrão ou em vasilhames individuais (RIGITANO, 1945; OJIMA et al., 1977).

'As principais pragas que atacam o pessegueiro são: as moscas das frutas, as cochonilhas, os ăcaros, os pulgões e a mariposa oriental. A incidência de doenças que afetam as plantas pode variar conforme as condições climáti-......... cas. As principais enfermidades são causadas pela ferrugem, sarna, podridão parda, bacteriose e gomose (BLEICHER \& TANAKA, 1982).

Com relação ao espaçaménto, nas clássicas baixas densidades de plantio, esse pode ser de $7 \mathrm{mx} 5 \mathrm{~m}$ em terrenos declinosos, e $6 \mathrm{~m} \times 5 \mathrm{~m}$ nos planos, e que correspondem "a cerca de 285 a 333 pessegueiros por hectare, respectivamente. Com essa densidade de plantio, plantas individuais adultas e bem tratadas produzem anualmente cerca de 50 a $90 \mathrm{~kg}$, ou se- 
ja, de 17 a 30 ton/ha. Outros espaçamentos bem mais adensados, ainda são adotados, a exemplo de: $6 \mathrm{~m} \times 3 \mathrm{~m}, 5 \mathrm{~m} \times 3 \mathrm{~m}, 4 \mathrm{~m} \times 2 \mathrm{~m}, 4 \mathrm{~m} \times \mathrm{lm}$, $4 \mathrm{mx} 0,5 \mathrm{~m}$, $3 \mathrm{~m} \times 2 \mathrm{~m}$ e até mesmo $3 \mathrm{mx} 0,5 \mathrm{~m}$ e $3 \mathrm{mx} 0,5 \mathrm{mx} 0,5 \mathrm{~m} \cdots$ (CAMPO-DALL'ORTO et al., 1984a) e 1,30mx0,4m (EREZ, 1982), alēm de outros, conforme è apresentado no ítem 2.4 .

Para haver crescimento mais ordenado e dirigido das plantas, o pessegueiro, deve ser submetido à poda de formação e de frutificação. A poda visa, em essência, o ritmo do crescimento e o potencial da frutificação, sendo mesmo indispensāvel para o sucesso da cultura persícola. 0 pessegueiro, quando cultivado em condições favoráveis, tende naturalmente a apresentar uma excessiva frutificação efetiva, fato esse que diminui a qualidade final dos frutos, básicamente no seu peso médio, além de causar um indesejável estresse à planta. O.raleio dos frutos, è feito atē a fase do endurecimento do caroço (azeitona), para safras de frutos de melhor tamanho, coloração e sabor.

o fruto destinado à armazenagem : frigorífica precisa apresentar um ponto de maturação firme, uniforme e livrẹ de danos mecânicos. Dependendo do cultivar, pode ser bem conservado em temperaturas baixas $\left(0\right.$ a $\left.2{ }^{\circ} \mathrm{C}\right)$, por dois-três meses, e ao ambiente natural à sombra por uma semana ou pouco mais. Na industrialização, o ponto apropriado é o intermediário entre ao de consumo e de frigorificação (RIGITANO, 1945; SÃO PAULO, 1982; SACHS, 1984). 


\title{
2.2. Desenvolvimento vegetativo do pessegueiro
}

\author{
2.2.1. 0 embrião e a plântula
}

O início da vida de uma planta se desenrola sob estrita dependência maternal. O desenvolvimento da oosfera fertilizada, ou seja, a embriogênese, se realiza graças ao suprimento nutritivo fornecido pelas células do aparelho reprodutor maternal. Quando o fruto desenvolvido se desprende da planta, o embrião, por sua vez, inicia uma nova vida totalmente autônoma, exposto. às "agressões" naturais do meio ambiente (MONET, 1983).

A semente (amêndoa) madura do pessegueiro è constituída por: um tegumento externo, que é formado de tegumentos do óvulo e de uma parte do nucelo degenerado; um tegumento interno, proveniente da parede do saco embrionário e das células regeneradas do albúmen e um embrião. 0 embrião por sua vez é constituído pelos primórdios foliares, cotilédones e radícula (TOMBOLATO, 1984).

O embrião do pessegueiro para suportar as adversidades do mejombiente, possui dois sistemas matunais de proteção. O primeiro deles constitue-se no caroço, envoltório lignificado da sémente, e no tegumento de amêndọ, que a protege das intempéries ou das agressões ..... mecânicas. o segundo sistema de proteção é de natureza puramente. bioquímica, que inibe o crescimento do embrião e o mantém em endodormência, durante tơda a estação fria. Nesse rperíodo 
de frio reduzem-se os níveis dos inibidores de crescimento, a exemplo do ácido abscísico ( $A B A$ ), que se encontram em altas concentrações nos tegumentos, cotilédones e eixos embrionários da semente. 0 embrião torna-se assim, metabolicamente ativo e apto a de desenvolver normalmente no inicio da estação seguinte, mais quente, ou seja; na primavera (BONAMY \& DENNIS JUNIOR, 1977; BARBOSA et al., 1987a; 1987b).

o fenômeno da endodormência do embrião constitui-se no melhor exemplo de adaptação da frutífera às condições do clima à sua sobrevivência em latitudes acima de $30^{\circ}$, onde o crescimento vegetativo ao natural é impossibilitado no inverno. Nos países de clima subtropical-temperado a tropical, as sementes do pêssego não sofrem as referidas agressões ambientais e são capazes de germinar em 'qualquer época do ano, desde que submetida a um certo período de frio-úmido artificial, para sua saída da fase de endodormência. As sementes quando não submetidas à quebra dessa endodormência, germinam deficientemente, e as plântulas resultantes apresentam-se anormais, com sintomas de "rosetas" ou ananismo. Essas anomalias, de caráter fisiológico, afetam seriamente as plântulas, caracterizando-se pelo enrolamento das folhas e inibição do desenvolvimento apical, resultando num indesejável retardamento vegetativo. Nesse caso, um período de 30 a 40 dias de estratificação a frio-ümido $\left(5-10^{\circ} \mathrm{C}\right)$, praticamente elimina a endodormência e as sementes germinam, podendo proporcionar plântulas completa- 
mente normais (BARBOSA et al., 1986; 1987b).

Ainda, além do tratamento e baixas temperaturas em condições úmidas e aeradas, a endodormência das sementes do pessegueiro pode ser até de certa forma interrompida pela ação de reguladores de crescimento, tais como o ācido giberélico $\left(\mathrm{GA}_{3}\right)$ e o 6-benzilaminopurina (6-BAP). Esses hormônios exercem papel fundamental no processo germinativo, estando envolvidos tanto na quebra da dormência, como no controle da hidrólise de reservas para o fornecimento de energia ao embrião, e na intensificação da atividade mitótica celular (DIAZ \& MARTIN, 1972; METIVIER, 1979; AMORIM, 1979).

Nos casos em que as sementes não germinam ou germinam deficientemente-pelo processo de estratifieação a frio-úmido, torna-se necessāria a adoção de outros métodos mais eficazes. Essa má germinação decorre, nos cultivares de maturação preooce."'pelı rápido ciclo de crescimento dos frutos em qué os embriões não se desenvolvem totalmente. Assim, alēm do período de frio-úmido, esses embriões imaturos precsam ser cultivados assepticamente in vitro,-sob meio de cultura artificial. Esse "meio" sintētico deve imitar as condições nutritivas naturais dos tecidos embrionários da planta mãe. Dessa maneira; o embrião rudimentar se desenvolve, e em poucas semanas jā apresenta um perfeito sistema radicular e aéreo (BARBOSA et al., 1983; 1984; 1985 e 1989b). 
No processo final de germinação de suas sementes, pode-se verificar elongação visível do eixo hipocótilo-raíz; contudo, a emergência do epicótilo é verificäda somente após transcorrida uma semana. Nessa fase, os cotilédones entumecidos, nas condições do solo, funcionam como à principal fonte de disponibilidade de nutrientes à "iântula no curso de formação de suas primeiras folhas e raízes. o período que compreende a germinação da semente até o estabélecimento da plântula como indivíduo independenté, constitui a fase mais crucial de seu desenvolvimento. E nessa época que se torna mais susceptível às lesões, causada's por diversos tipos de pragas e fungos parasitas; além de que um deficit de água ou outra alteração brusca da natureza, pode ser rapidamente fatal.

Decorridos aproximadamente quinze dias da emergência, a plântula apresenta cerca de três pares de folhas fotossinteticamente ativas e bem desenvolvidas. 0 sistema radicular nessa época compreende: uma raíz primāria, vārias secundārias e algumas terciārias. Em condição ambiental apropriada, as plântulas do pessegueiro podem atin-

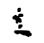
gir em um mês, cerca de $25 \mathrm{~cm}$ e apresentar até dez pares de folhas. Esse desenvolvimento inicial da plântula è de 
caráter exclusivamente vegetativo, caracterizando assim a sua típica fase de juvenilidade.

2.2.2. Juvenilidade e maturidade das plantas

As angiospermas, durante a sua primeira fase da vida, passam por um período de juvenilidade, em que a floração não ocorre naturalmente. Esse perỉodo ē caracterizado por um estádio morfo-fisiológico típico, em que o meristema das gemas vegetativas não responde à floração, mesmo que as condições propícias para tanto estejam presentes (JANICK, 1968; SCORZA, 1982).

A juvenilidade das plantas se eștende desde o final da germinação da semente, atē a primeira indução floral (JONKERS, 1971; MONET, 1983). Em plantas lenhosas, a primeira indução floral pede ooorrer precocemente, pouco meses após a germinação da semente, atē mesmo após período muito longo, envolvendo várias décadas, como é o caso de algumas espécies do gênero Pinus. A indução floral é extremamente condicionada pelos fatores ambientais e principalmente gẹnēticos (JACKSON \& SWEET, 1972;-WESTOWOOD, 1978). Cada planta possui codificado em seu genótipo, o "tempo" exato para a indução e desenvolvimento dos primórdios florais (ZIMMERMAN, 1972).

As plantas decíduas juvenis, ao lado de sua inabilidade à floração, ainda podem ser distinguidas por várias outras caractenísticas morfológicas e ... físiológicas, 
tais como: presença de espinhos; folhas lisas, lobuladas; caules rasteiros, esverdeados, ramificação e enfolhamento vigorosos; fácil enraizamento; ramos com internós.. longos; resistência às doenças, além de outras. Do ponto de vista bioquímico, destaca-se a menor concentração dos ácidos nucléicos. : DNA e RNA (äcido desoxirribonucléico e ácido ribonucléico), irespectivamente, em seus tecidos foliares. :Assim, hipoteticamente se discute, que o DNA inativo, nessa fase precace, não sintetiza o m-RNA (RNA-mensageiro) específico, para a produção das "proteínas florais" no citoplasma da célula; com isso, a taxa de DNA/RNA em tecidos de plantas juvenis tende a ser inferior (ALI \& WESTWOOD, ...1966; JACKSON \& SWEET, 1972; ZIMMERMAN, 1972; WESTWOOD, 1978 ; BUDAN, 1982).

Essa juvenilidade parece àinda permanecer "in situ" mesmo em plantas adultas, pois se forem submetidas a um corte drástico, abaixo de um certo limite chamado. de transição, as novas brotações das gemas latentes novamente apresentarão as características juvenis. Tal fato deve justificar a teoria do "gradiente de juvenilidade", presente nos troncos, delimitando a planta em dois tecidos distintos: o juvenil e o adulto. Em plantas enxertadas, é comum verificar brotações juvenis, oriundos do porta-enxerto, contrastando com à copa, que é perfeitamente adulta (WESTWOOD, 1978). No pessegueiro juvenil, as características mais distintas podem ser evidenciadas pelo seguinte: 0 seu 
hábito vegetativo vigoroso, ereto e sempre verde; internódios mais longos e presença de "rosetas" nas plântulas, de condições de período de frio insuficiente, durante o processo de germinação, além é claro, da incapacidade de florescer. A juvenilidade nessa frutífera se estende até um período de três anos, dependendo de seu genótipo, das condições ambientais, e se enxertadas ou não.

Generalizando, os requerimentos essenciais para a transição da fase juvenil a sua transformação para àdulta são: endógenos - o grau de desenvolvimento e a idade fisiológica da planta; o Índice de área foliar (capacidade fitossintética), a relação carbono/nitrogênio; as concentrações favoráveis dos reguladores de crescimento; o número de ciclos mitóticos; a distância mínima entre os meristemas e as raízes (SCORZA, 1982); exógenos - o fotoperíodo, a temperatura, o balanço hídrico (BROWN, 1952; PIRINGER \& DOWNS, 1958; SALISBURY, 1982; GRIERSON et al., 1982).

Afora todos esses estudos teóricos e hipotéticos, e outros de carāter estritamente bọtânico, as pesqui-

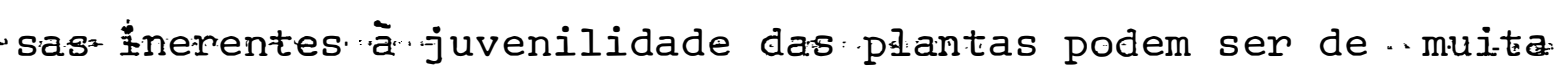
práticabilidade aos melhoristas de frutíferas; constituem, pois, um direcionamento bástante promissor para o próprio aperfeiçoamento dos trabalhos de melhoramento genético de espécies que apresentam ciclos longos de juvenilidade.

0 pessegueiro em sua fase adulta, caracteriza-se por sua aptidão à reprodução e pelo seu comportamento 
cíclico anual. A cada ano, de acordo com as características peculiares da estação climâtica, a planta apresenta uma fase de crescimento e outra de formação de seus. órgãos. ... re= produtivos.

Na primeira fase, em estações quentes, ocorrem os processos de organogênese: formação de folhas, frutos, gemas e outras estruturas anatômicas complexas. Na segunda fase, ocorrem a diferenciação e o desenvolvimento das flores que darão origem posteriormente à semente, constituindo assim, um dos meios básicos de dispersão e de perpetuação da espécie. Um dos estádios de realce da segunda fase, é em particular, caracterizado por mudanças essencialmente bioquímicas, fazendo com que o crescimento vegetativo seja praticamente paralisado. Após esse período em endodormência, o pessegueiro floresce, frutifica e retorna novamente à sua ativa fase vegetativa, iniciando assim mais um ciclo anual de desenvolvimento.

Em sua multiplicação comercial, o pessegueiro é comumente propagado via vegetativa, através da enxertia de gemąs adultas para garantir produções precoces de frutos, uma vez que essas não revertem à juvenilidade. A propagação via seminífera è em geral utilizada pelo homem, para a produção de porta-enxertos ou nos trabalhos de melhoramento genético da espécie, para a seleção dos genótipos de interesse. 
24 .

\subsubsection{Dormência das plantas $\forall$}

Dormência ê o termo utilizado para denotar um certo estado inativo da planta, em que o crescimento vegetativo não è verificado (JANICK, 1968; WESTWOOD, 1978). Essa suspensão visível e temporária do crescimento, está relacionada com algumas estruturas das plantas que contém meristemas (LANG et al. 1987).

A dormência nas plantas constitui, pois, um mecanismo fisiológico adaptativo, especialmente para enfrentar as condições adversas do meio em que vive, por exemplo : do estresse hídrico, temperaturas baixas, de nutrição deficiente, alēm de outras limitações de carāter endógeno.

Devido a existência de uma excessiva terminologia que conceitua a palavra dormência, foi proposta, recentemente, uma classificação definitiva para a caracterização das diversas manisfestações. desse comportamento : fisiológico. Essa nova claşsificação, baseia-se nạ adição de três prefixos gregos à palavra dormência, a saber: eco-, para- e endo-. Então, de forma simples e uniformizada, os termos: ecodormência, paradormência e endodormência. podem ser mundialmente empregados. Por exemplo, preservando o prefixo grego durante a tradução, a endormência pode equivaler a: "endodormancy" em inglês; "endodormance" em francês; "endodormienza" em italiano; "endodurmiente" em espanhol; "endoschlafendes" em alemão, e assim por diante (LANG et al. 1987). 
- Ecodormência refere-se a todos os casos de parada de crescimento, regulado por fatores ambientais eventuaris como: temperaturas extremas, secas, excesso de umidade e outros.

- Paradormência pode ser causada, por exemplo por certos sinais bioquímicos, que emanados de regióes distintas da planta (meristema apical), afetam o crescimento de algumas de suas estruturas (gemas laterais, folhas). Pode ainda acontecer em respóstas à variação do fotoperiỏo.

- Endodormência ocorre em função de estímulos. específicos ambientaes (frio, fotoperíodo) ou endógenos (concentração hormonal), causando a parada de crescimento da planta.

0 tipo de dormência que mais afeta 0 . desenvolvimento do pessegueiro è a endodormência, verificada no outono e inverno, principalmente em regiões temperadas. Em latitudes mais próximas do Equador, pode ocorrer somente nas épocas mais frias ou secas do final do outono e inicio de inverno (FIGURA I).

+

De maneira geral, o processo da endodormênciä é desencadeado durante 0 encurtamento dos dias. Nesse período, as folhas maduras funcionam como receptoras de mensagens do espectro solar, possibilitando a ação do mecanismo de conversão dos pigmentos fitocromáticos. Esses fotoreceptores, motivados pelo estímulo externo. (noites longas), são 


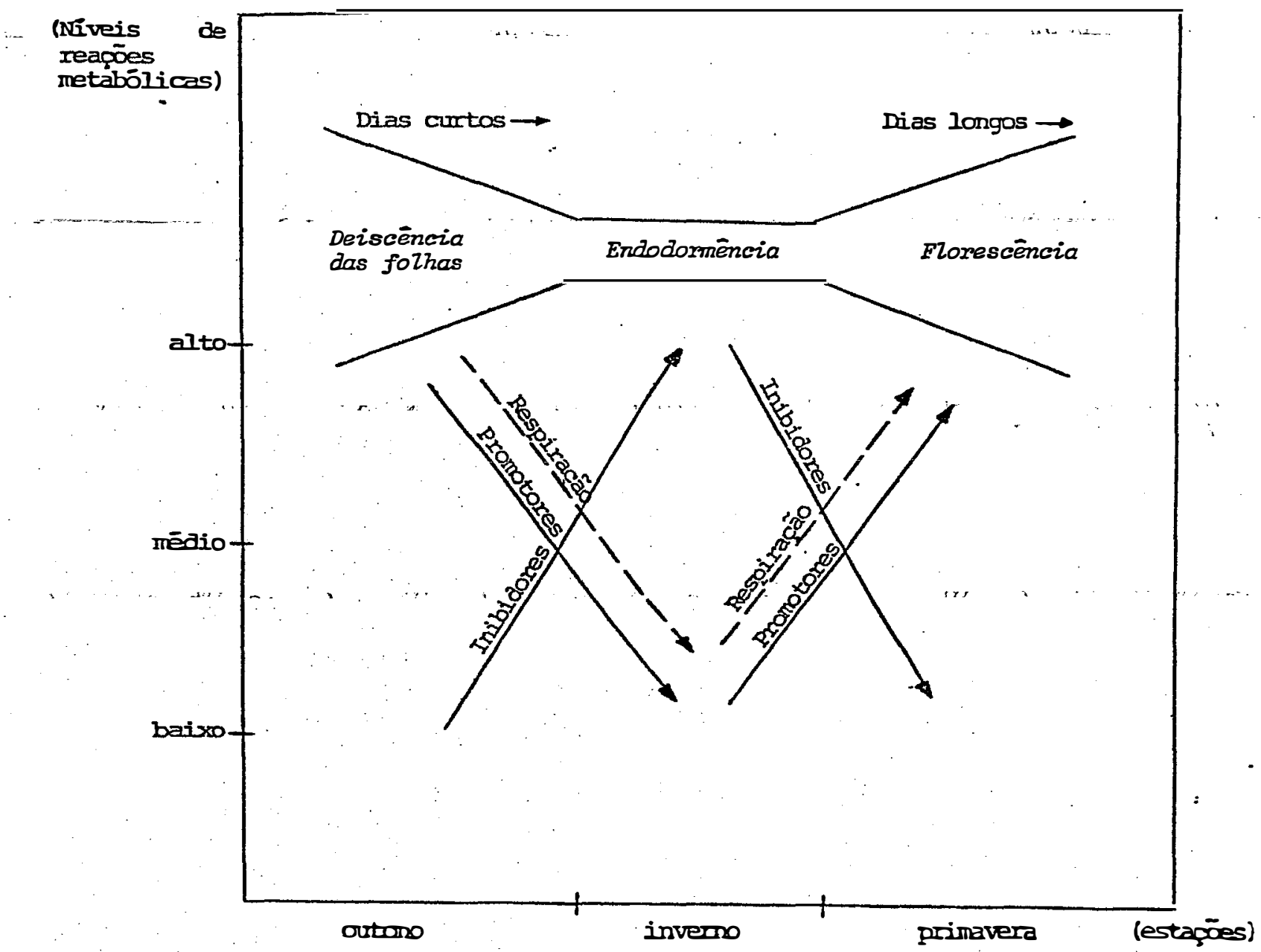

FIGURA 1. Desenho esquenätico mostrand os niveis enāgenas de horminios prantores e inibidores de crescirento, ber cow da respiracão, de acorda com o tertuperíables taciomal $\because$ (IAVEE, 1972, modificado)

$-$ 
ativados e proporcionam às células a capacidade de síntese dos hormônios inibidores específicos.

o ãcido abscísico ( $A B A)$, por exemplo, é sintetizado pelas folhas, já a partir do final do verão, e logo após, no outono, atingem elevadas concentrações, o que culmina com a abscisão das folhas e consequlente inibição do crescimento. No pessegueiro, em cultivares mais exigentes de frio, a concentração desse inibidor chega alcançar 2,5 ug/grama de tecido. Os materiais desenvolvidos para regiões subtropicais possuem cerca de 0,75 ug/grama de tecido. (BROWEN \& DERICKSON, : 1978).

Essa inibição do metabolismo celular, deve-se ao bloqueio da síntese de RNA específico, inibindo diretámente a indução do $\mathrm{GA}_{3}$ e a produção de enzimas responsáveis pelo processo de crescimento da planta.

Certos inibidores de crescimento, tais como: cloreto de (2. aloroetil) trimetilamônio..(CCC), ácido succí-........... nico-2, 2-dimetilhidrazida (SADH) e outros bloqueadores de síntese de $\mathrm{GA}_{3}$ e IAA, tambëm paralisam a planta e estimulam a irricicção floral do pessegueiro.

Esse complexo sistema inibidor que condiciona a endodorméncia, durante o período de frio prolongado, parece ser enzimaticamente alterado, o que viria possibilitar a elevação dos níveis dos promotores de crescimento. Desta forma, novamente funcionais, estes voltariam a proporcionar às células o seu rítmo metabōlico normal. 
Dentre os diversos cultivares de pessegueiros existentes, cada um, em particular, exige período de frio específico para desencadear o seu processo de quebra de endodormência. Adota-se mundialmente, o parâmetro de número de horas de frio abaixo de $7,2^{\circ} \mathrm{C}$, para que ocorra a adequada brotação das plantas. Constitui em última análise, o padrão da exigência de frio dos diversos materiais.

Os pessegueiros das regiões temperadas podem. exigir a devida quebra da endodormência, entre 600 a 1200 horas de frio abaixo de $7,2{ }^{\circ} \mathrm{C}$. Esses materais não se adaptam a regiões de pouco frio hibernal, pois ao entrarem em endodormência, deficilmente voltam ao estado vegetativo.

Em regiões de clima subtropical, o parâmetro de temperatura abaixo de $;, 2{ }^{\circ} C^{x-v}$ em sendo aos poucos tuídos por outros. Em São Paulo, o parâmetro de $13^{\circ} \mathrm{C}$ de temperatura pode ser adotado para algumas regiões de cultivo, pois as horas de frio acumulauas (abaixo de $7,2^{\circ} \mathrm{C}$ ) sãom prá ticamente despresíveis. A região mais fria do estado, Campos de Jordão, soma no inverno cerca de 200 horas de frio abaixo de 7,2 ${ }^{\circ}$ C. - A A região de Campinas, SP, acumula em métrar, no inverno, cerca de apenas 20 horas de frio abaixo de $7,2{ }^{\circ} \mathrm{C}$ (PEDRO, JUNIOR et al., 1979).

Na prática persícola de regiões tipicamente subtropicais, é realizado no inverno um tratamento químico desfolhante e estimulador de brotação das gemas. Esse re- 
curso torna-se obrigatório, pois o outono e o inverno são ineficientes na senescência das folhas e à quebra da endodormência. 0 desfolhante químico parece causar certo estresse à planta, que em decorrência aumenta a taxa respiratória das células, culminando com a saída de endodormência (SHULMAN et al., 1983). Dessa maneira, o pessegueiro vegeta e frutifica regularmente, mesmo em condições atípicas.

0 pessegueiro quando não sofre a interferência do persicultor, permanece, em parte, com as suas velhas e inúteis folhas do ciclo anterior. Em decorrência disso, as gemas se desenvolvem assincronicamente, prejudicando a necessāria regularidade da floração e da frutificação, além de favorecer a reciclagem de doenças.

0 recurso da poda de ramos "endodormentes" do pessegueiro, logo após a aplicação dos produtos quỉmicos, pode também auxiliar no desenvolvimento das gemas. A eliminação da porção superior do ramo proporciona a quebra da dominância imposta pelo meristema apical. A dominância apical é um fenômeno conhecido em muitas espécies vegetais.

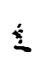

Aproximadamente após 30 dias do chamado tratamento de inverno, ocorre a plena floração do pessegueiro. Suas gemas vegetativas normalmente iniciam um crescimento visivel poucos dias após a abertura total das flores. Em certos cultivares, porém, a exposição das gemas flonais e vegetativas pode ocorrer simultaneamente, como é o caso dos 
materiais mais aclimatados geneticamente.

Com o avanço dos trabalhos de melhoramento genético do pessegueiro em regiões subtropicais, acredita-se que num futuro próximo, alguns materiais poderão comportar-se de forma similar às espécies tropicais, a exemplo do Coffea arabica, que the é análogo em diversos aspectos ontogenéticos, conforme as pesquisas de GOUVEIA (1984). 


\subsection{Desenvolvimento Reprodutivo do pessegueiro}

As etapas que conduzem a formação da flores do pessegueiro são as seguintes: a indução floral, a iniciação floral e o desenvolvimento da flor.

\subsubsection{A indução floral}

0 pessegueiro é considerado uma planta brevediurna (NITSCH, 1957), e sua indução floral se inicia no verão, depois de uma etapa de intenso crescimento vegetativo (MONET \& BASTARD, 1970). Caracteriza-se por uma fase de mudanças metabólicas que induzem a diferenciação das gemas do estãdio vegetativo à condição reprodutiva (JRAIDI, 1983).

No pessegueiro, as primeiras modificações histogênicas das gemas que conduzem à iniciação floral foram caracterizadas por TOMBESI (1965). O autor constatara que a gema é induzida à floração de modo definitivo, quando a túnica do meristema, que na forma indiferenciada possui de três.a quatro camadas de células, passa a ser formada por uma ou duas, mudando da sua forma cônica predominante para achatada.

Nessa fase, devido ao encurtamento dos dias, o sistema fitocromo presente nas folhas absorve a luz na faixa do vermelho tornando-se fisiologicamente ativo. Desta forma, há transmissão de estímulos às células, as quais pro- 
duzem os hormônios específicos para a indução e diferenciação floral. O responsâvel pelo estímulo da floração foi considerado como sendo um hormônio: o "florígeno"; embora este ainda não tenha sido completamente isolado ou identificado. O fitocromo parece agir, controlando a ativação de um complexo de gens, os quais funcionalmente ativos condicionam as primeiras modificações do meristema. Em decorrência, a atividade do anel inicial (2) é anulada, diminuindo assim consequentemente a produção de folhas (SEARLE, 1965; KENDRICK \& FRANKLAND, 1981).

Nesse momento da vida do pessegueiro, torna-se bem evidente a interação dos três níveis de controle do desenvolvimento. Esses são: o controle genético ou intracelular, o hormonal ou intercelular, e o ambiental ou extracelular.

A indução floral não afeta, contudo, todas as gemas, algumas conservam as suas características vegetativas, o que garante a perenidade da árvore, e em ültima análise, a perpẹtuação da espécie.

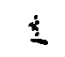

( $\left.{ }^{2}\right)$ Segundo CLOWES (1972), o anel, na escola francesa denominado de "anneau initial", constitui-se na região morfogenética mais importante do ápice, localizado logo abaixo do domo meristemático (summit), onde se formam os primórdios foliares. O domo é referido como sendo "meristème d'attente", inativo na produção de folhas, porém, imprescindível na formação da flor. 


\subsubsection{A iniciação floral}

A iniciação floral è caracterizada por modificações morfológicas do meristema, que se transforma irreversivelmente em flor. Essas transformações ocorrem no domo do meristema, que limita o desenvolvimento vegetativo e corresponde ao período de inibição da própria formação dos primórdios foliares. Em seguida, o meristema apical passa por intensa atividade mitótica e o domo apical aumenta consideravelmente. Esta fase se constitui ao estádio "pré-floral" citado por MONET \& BASTARD (1970), que no pessegueiro é perceptível, na França, durante o mês de agosto, no início do verão. Em seguida, o domo apical forma o receptáculo da flor, diferenciando sucessivamente, as sépalas, as petálas, os estames e o pistilo.

$$
\text { Os estádios morfo-histológicos florais do }
$$
pessegueiro segundo MONET \& BASTARD (1968), para o cv. May Flower, nas condições francesas, foram considerados os seguintes: 
Estâdios

a - (10 de agosto)

b - (meados de agosto)
Características

- início da fase transitória, com diminuição do funcionamento plastocrônico e arredondamento do domo apical;

- final da fase transitória, com parada do funcionamento plastocrônico e formação do receptáculo floral:

c - (meados a fins de agosto) - início da formação das sêpalas;

d - (final de agosto)

- formação das pétalas;

e - (início dè setembro)

- início de formação dos estames;

f. - (meados a fins de setembro) - início da formação do pistilo; e

$g-($ outubro)

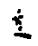

- final da formação do pistilo e assim, da própria flor. As células reprodutivas estão aptas à meiose, para a produção dos gametas masculinos e femininos. 
Depois do estádio "a", fase transitória, à completa formação da flor (estādio "g"), o primórdio floral apresenta intensas divisões celulares. Entre os estádios "g" e a meiose, não se observam tais divisões (MONET BASTARD, 1969).

O desenvolvimento das partes florais não acontece sempre na mesma intensidade. Distinguem-se, nesse particular, três períodos principais, logo após o desenvolvimento inicial da diferenciação floral:

- Primeiro período: ocorre no final do verão; a intensidade do crescimento è elevada; esse período coincide com a iniciação do botão floral.

- Segundo período: ocorre durante o outono e inverno; hã uma drástica diminuição do crescimento; os orgãos reprodutivos se formam lentamente.

- Terceiro período: ocorre pouco antes do final do repouso hibernal; a meiose se inicia; o pessegueiro. reinicia rapidamente o seu crescimento (MONET \& BASTARD, 1968). - A evolução crónológica de uma gema floral é distinguível macroscopicamente por vários estádios fenológicos. A designação de cada. estādio é feita frequentemente por letras sequenciais, a facilitando, assim a comunicação entre pesquisadores, técnicos extensionistas e produtores, no que concerne às épocas de realização das mais importantes 
práticas culturais, a exemplo da poda, aplicação de produtos para quebra de dormência, pesticidas, fitohormônios e fertilizantes.

A fenologia floral do pessegueiro, foi ainda pesquisada por outros autores, a exemplo de BAGGLIOLINI \& CHELLER (1954), que estabelecera uma classificação cronológica para os diversos estádios.

Como os cultivares de pêssegos podem apresentar flores de dois tipos: "rosáceas" e "campanuladas", SAUNIER $(1964)^{(3)}$, citado por JRAIDI (1983), aperfeiçoou a classificação de BAGGLIOLINI \& CHELLER (195̆4) e propôs aos dois tipos de flores referidos, a seguinte:

Classificação

A

B

C

- gema de inverno (dormente);

- gema inchada, aparecimento do cálice;

- flor rosácea: aparecimento da coro$\dot{4}$ la; flor campanulada: aparecimento da corola e do estigma;

( $\left.{ }^{3}\right)$ SAUNIER, R. Morphologie de la fleur de pêcher. Compaparaison des types rosäcés et campanulẻs, 1964 (não publidado ) 
Classificação

D

$E$

F

G

$\mathrm{H}$

I
Estädio

- flor rosácea: botão rosa adiantado (balão); flor campanulada: estames emergentes acima da corola;

- abertura parcial da flor;

- exposição das pétalas (fior aberta);

- deiscência das pétalas;

- deiscência do cálice; e

- fruto jovem em crescimento.

2.3.3. Desenvolvimento floral e maturação dos.gametas

o desenvolvimento floral é caracterizado pela interrupção da endodormência, que promove a retomada do crescimento dos orgãos florais e a maturação das células reprodutivas pela meiose, culminando com a abertura da flor.

No caso de pessegueiros de regiões de latitudes baixas, do hemisfẹrio Sul, a exemplo de São Paûlo $\left(23^{\circ}{ }_{30}\right)$, a meiose pode ocorrer de abrili a jultho. Na França, os estudos conduzidos por MONET \& BASTARD (1970), mostraram que a referida meiose ocorre em fins de dezembro. A partir deste evento, os orgãos florais se alongam até a abertura da gema, à plena floração · da planta. 
2.3.3.1. Formação do saco polínico e dos grãos de pólen Nos primórdios do desenvolvimento da gema florifera, as células iniciais do saco polínico, denominadas arqueósporos, começa a se dividir. Cada arqueósporo divide-se tangencialmente em duas outras células; uma externa, denominada célula parientał primāria, e outra interna, denominada célula esporogênica (JRAIDI, 1983).

MARTINEZ-TELLES (1981) acompanhou a evolução simultânea da parede do saco polínico e da própria diferenciação de células esporogênicas da nectarina cv. Independence. As células esporogênicas envolvidas pelo "tapetum" ocupam o centro de cada um dos futuros sacos polínicos. Multiplicam-se por mitoses sucessivas, durante 15 a 20 dias, para formar um maciço esporogênico de células-mãe primordiais diplóides.

Na meiose cada célula mãe primordial origina quatro células haplóides (tétrades). Cerca de duas semanas após a meiose, o "tapetum" degenera-se e as tétrades desintegrăm-se liberando os quatro grãos de pólen dentre de um líquido nutritivo. Os grãos de pólen em formação apresentam forma triangular, a qual è característica da éspécie.

Algum tempo depois, antes porém da ântese (abertura da flor), os quatro sacos polínicos de cada antera se reduzem a dois e as células da parte central externa 
se desidratam, permitindo a deiscência das anteras e a dispersão do pólen.

2.3.3.2. A formação dos óvulos e do aparelho carpelar

A diferenciação do orgão feminino (pistilo) deve ocorrer nas condições brasileiras, em final do verão e no início do outono, devendo variar de uma região à outra. Nesse período, os bordos das folhas carpelares, em formação nas gemas axilares, se desenvolvem, culminando com - aparecimento do pistilo. Sua base então engrossa e a cavidade ovariana aumenta de volume. O estigma se diferencia com o alongamento do pistilo e o obturador, por sua vez, se desenvolve sob a forma de duas massas celulares adjacentes, que crescem da base do pistilo por volta de cavidade ovariana. Quando o pistilo atinge seu tamanho definitivo, uma série de vasos longitudinais desenvolvem-se a partir do funículo (ponto de inserção da placenta ovular) (JRAIDI, $1983)$.

Os óvulos se desenvolvem à partir de dois "mamelões" colaterais, da parte mediana dos bordos das fothas carpelares. São originados por células chamadas "células da calota", que dão origem ao núcleo e à célula-mãe do saco embrionário. Essas duas células acompanham simultaneamente e evolução do óvulo até a sua maturidade. No gênero Prunus, dois óvulos se desenvolvem no interior de cada ovário. No início eles crescem num mesmo rítmo e, 
após a floração, um deles continua crescendo e o outro interrompe seu crescimento, degenerando-se em seguida (DUTROCHET, $1822^{(4)}$; PECHOUTRE, $1902^{(5)}$; citados por TOMBOLATO, 1984 ; HARROLD, 1935).

o óvulo do pesseguiero no curso de seu desenvolvimento sofre dois movimentos sucessivos: no primeiro se desenvolve na horizontal, perpendicularmente ao eixo do pistilo, e depois, sofre uma rotação, para a posição vertical, paralela à sutura do carpelo (MARTINEZ-TELLEZ, 1.981).

Poucos dias antes da floração; pelo processo da meiose, origina-se uma tétrade de macrósporos. 0 macrósporo chalaziano (próximo à chalaza) desenvolve-se e os três outros degeneram-se rapidamente. O núcleo desse macrósporo funcional se divide em dois núcleos migratórios, que se dirigem separadamente para os polos de um grande vacúolo. Esses núcleos se dividem duas vezes sucessivamente, de sorte que alguns dias antes da florada, o megagametófito se apresenta com oito núcleos; quatro micropilares (próximo

$\left({ }^{4}\right)$ DUUTROCHET Recherches ser I'laccroissement et al reproduction des végétaux. Mémoires du Museum, tomo 8, 1882. ( ${ }^{5}$ ) PECHOUTRE, F. Contributions à I'étude du développement de I'ovule et la graine des rosacées. Paris, 1902. ...Thèse (Docteur-Faculté des Sciences). 
a micrópila) e quatro chalazianos. Essa estrutura octonucleada resultante, que ocupa boa parte do óvulo, ê o saco embrionário, formado cerca de dez dias da antese. Desses dois grupos, um núcleo migra para o centro da célula e origina os núcleos polares. A tríade micropilar constitui o aparelho oogonial: uma oosfera e duas sinérgides. $\dot{A}$ tríade chalaziana, formada de três antípodas, degenera rapidamente após a fusão dos núcleos polares com o generativo, coincidindo no tempo, praticamente com a plena floração. As sinérgides persistem aproximadamente uma semana após a fertilização. O saco embrionário começa a se alongar e praticamente dobra de tamanho no momento da fertilização, e em duas semanas atinge a chalaza (HARROLD, 1935; JRAIDI, 1983).

\subsubsection{Floração, polinização e fertilização}

A florada do pessegueiro, em plantas individuais, pode persistir de uma a duas semanas, dependendo dos cultivares, dos fatores internos e das condições do ambiente. Em São Paulo, a floração ocorre, normalmente, entre os meses de junho e julho, e à exceção das regiões mais frias,

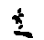
as qüedas de temperatura, normalmente não causam danos sérios às flores e aos frutos jovens.

As flores do pessegueiro permanecem exuberantes até o momento da fertilização da oosfera, sendo que em seguida começam a perder o viço, culminando com a queda das pétalas em poucos dias. 
A polinização, em última análise, ven a ser a transferência dos grãos de pólen das anteras para o estigma do pistilo; é realizada com maior efetividade pelos agentes polinizadores, a exemplo do vento e dos insetos. No pessegueiro, devido a predominância da autopolinização entre as flores de uma mesma planta, não há necessidade estrita de ocorrer a polinização cruzada.

0 processo da polinização-fertilização é 0 mais importante elo na cadeia reprodutiva de uma planta, pois deste depende toda a sua produção frutífera. Assim sendo, o conhecimento dos fatores ou das condições que o podem afetar, constitui um elemento de real valor ao entendimento das causas da baixa frutificação efetiva, em alguns casos, e para o planejamento de metodologias que a aprimore $\therefore$ (MELLENTHIN et al., 1972; MEDEIROS, 1979).

A germinação do grão de pólen do pessegueiro, ocorre pouco tempo após ao contacto com o tecido do estigma. Artificialmente, através da germinação in vitro, o crescimento do tubo polínico é verificado ao redor de 60 minutos. A utịlização de "meios de cultura", com maiores concentracões de açúcares e micronutrientes, não proporciona aumento de germinação. Excelente germinação, no entanto, pode ser verificado quando o "meio" é constituido da solução salina de MURASHIGUE \& SKOOG (1962), acrescido de 5\% de sacarose, 0,6\% de agar e com $\mathrm{pH}$ elevado próximo a 6,0. 0 poder germinativo dos grãos de polén, pode perdurar por vârios meses, 
desde que armazenados em ambiente de frio seco (BARBOSA et al., 1989 a).

Nas drupāceas; a porcentagem de grãos de pölen normais, geralmente é superior a $85 \%$, a exceção dos híbridos interespecíficos (REMY, 1953). Em pessegueiṛ, a porcentagem de grãos viāveis varia de 70 a 95\%, dependendo dos cultivares (FLORY \& THOMES, 1943; DETJEN, 1945; BREVIGLIERI, 1958; KELESNIKOV, 1964; BARBOSA et al., 1989:C). 0 poder germinativo dos grãos de pólen, normalmente é ìnfluenciado por diversos fatores internos, como por exemplo; o estado nutricional da planta (WILLIAMS, 1970); o desenvolvimento da flor em relação a suä posição no ramo (REMY, 1953); o estado sanitário, como certas infecções virais (MARENAUD \& SAUNIER, 1974), alẻm das condições externas como a temperatura, a hidrometria e outras (MARTINEZ-TELLEZ, 1981).

Nessa fase, a alta sensibilidade das plantas por temperaturas tanto amenas como elevadas, representa um grande risco de danos às flores. No caso de temperaturas elevadas, características do clima subtropical-tropical, quanḍjo acompanhadas de baixo grau de umidade, tanto no solo como no ambiente, podem causar a abscisão da flor. 0 tubo polinico continua crescendo até a temperatura de 32 a $37^{\circ} \mathrm{C}$ (GOURLEY \& HOWLETT, 1949).

Os pessegueiros mais adaptados ao clima subtropical-tropical, chegam a produzir de 1000 a 2000 grãos de pölen por antera, e até 80.000 por flor. A viabilidade des- 
ses grãos de pólen varia normalmente de 60 a 95\%, quando bem conservados ou recém-colhidos e em condições de laboratório (BARBOSA et al., 1989.c).

A produção e a germinação do pólen do pessegueiro parece não ser constante ao longo dos anos: BASSOLS (1980) relata algumas alterações ocorridas do um ano para outro, em cvs. gauchos como: "Capdeboscq", "Cerrito", "Cheripa" e "Coral".

Durante a fertilização, hã a fusão do primeiro núcleo generativo do pólen com núcleo feminino do óvulo (oosfera), encerrando assim o período haplóide da gema floral do pessegueiro. A oosfera fertilizada dá origem ao zigoto diplóide. 0 segundo núcleo generativo fundido com os núcleos polares, forma um tecido triplóide, o endosperma da semente (amêndoa).

Assim, após essa dupla fertilização, termina a reprodução sexuada do pessegueiro, sendo que o embrião continua sua formação no interior do fruto em crescimento.

\subsubsection{Frutificação}

0 conhecimento do processo de frutificação de uma espécie, bem como dos demais fatores interrelacionados, é extremamente importante ao discernimento de algumas práticas culturais, aos exemplos da poda, do raleio de frutos, do uso de fertilizantes e de reguladores de crescimento. As estimativas da colheita, bem como do tamanho final dos 
frutos, estão intimamente relacionadas com as características de frutificação da espëcie (WESTWOOD, 1978).

O fruto do pessegueiro é o resultado do desenvolvimento e da diferenciação das paredes do ovário. A oosfera desde que fertilizada, dá origem a um embrião que é responsável em parte pelo crescimento normal dos frutinhos. Estes porém podem ser abortados, se por qualquer motivo, o seu embrião for destruído antes do endurecimento do caroço (MONET, 1983).

Ressalte-se no entanto, que após a polinização da flor e a fertilização da oosfera, muitos outros fatores podem estar influenciando na taxa de pegamento, no crescimento, no tamanho (peso) e na qualidade final dos frutos.

Em geral, as relações hormonais são, em grande parte, diretamente responsáveis pelo sucesso da frutificação. Do balanço exato entre as auxinas, giberilinas, citocininas e: o etileno, depende a persistência do fruto 'à planta; cada espécie em particular, requer uma combinação ou uma taxa hormonal específica para a sua adequada frutificação.: Os sítios de síntese desses hormônios localizam-se no próprio frutó em desenvolvimento, o que determina as taxas de pegamento e de crescimento. Os fatores externos como temperatura, água, umidade e outros, podem afetar significativamente a frutificação de planta (WESTWOOD, 1978). 
das proximidades do tecido do pistilo, parecem ser inicialmente suficientes para o apropriado pegamento do fruto e desenvolvimento do embrião da maioria das espécies (GREULACH, 1974 ).

No caso específico do pessegueiro, o. crescimento e o desenvolvimento do fruto e da semente estão intimamente relacionados com a periodicidade de sintese da auxina AIA (ácido indol-acético). Tal variação periódica (cíclica) proporciona uma relação de causa-efeito bastante evidente em algumas fases do período de sua frutificação.

Segundo POWELL \& PRATTI (1966) e CRANE (1969), nos primeiros estádios de crescimento do fruto, há a formação do embrião e o consequente endurecimento do caroço. Nessa fase, o nịvel de AIA bastante elevado, paralisa a formação da polpa. Esta somente retoma seu crescimento quando o endocarpo aumenta seu peso em matéria seca, o que coincide com a diminuição da concentração de AIA aos níveis similares do momento da floração. As concentrações de giberilinas e citocininas por sua vez, que são maiores durante os primeiros địias da frutificação, diminuem gradativamente, até a formação completa do fruto. Na fase final da maturação, eleva-se o nível de etileno, culminando com a abscição do fruto.

Pesquisas relacionadas com a frutificação do pessegueiro, foram bastante divulgadas durante as décadas 
de 20 e 30 (DORSEY \& MACMUNN, 1926: 1.927; 1932; LILLELAND, 1932; LOTT, 19.32; 1933; RAGLAND, 1934; HARROLD, 1935; TUKEY, 1933); restringiram-se porém, a um mínimo na literatura disponível, por aproximadamente 35 anos. Na década de 70, LILLIEN-KIPNIS \& LAVEE (1971), estudando a frutificação do pêssego. "Ventura", detalharam a caracterização dos estádios de crescimento dos frutos. O estádio I, para esse cultivar, compreende os primeiros 35 dias após a floração, que é racterizado pelö rápido crescimento do pericarpo. No estádio II, aproximadamente de 36! a 49\% dia após a floração, ocorre a parada de crescimento do pericarpo e o endocarpo inicia a sua lignificação. Após o 510 dia da florada, inicia-se o estádio III, que é caracterizado por um intenso e contínuo crescimento do pericarpo: este estádio perdura até a maturação do fruto.. o desenvolvimento dos integumentos e do nucelo é contínuo até atingir o tamanho máximo, ao término da nona semana após a floração. O embrião por sua vez, desenvolve-se após a sétima semana. Os cotilédones formam-se próximo ao 60 \% dia, alcançando os seus tamanhos máximos, três meses após a plena florada.

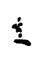

Nesse processo de crescimento, a temperatura parece exercer papel importante na maturação e na qualidade dos frutos. Se ocorrer, por exemplo, queda brusca e contínua na temperatura, reduzindo o metabolismo da planta, principalmente durante o estadio II, o ciclo total de crescimento dos frutos pode ser bastante afetado, pois o estádio 
III somente se inịcịa após o total endurecịmento do caroço $(6)$.

- O ciclo de maturação dos frutos do pessegueiro, pode também variar consideravelmente, dependendo das características genéticas de cada cultivar. Existem materiais com ciclos da florada à maturação, desde 60 até acima de 200 dias. Para esses materiais com diferentes ciclos de maturação, a duração dos estádios I e II pode diferir em apenas cinco a dez dias; grande variação, porém, pode ser verificada no estádio III, durante o crescimento final da polpa.

Outros parâmetros como a "densidade frutífera" (X) e o "potencial produtivo" (Y) dos cultivares, podem ser estimados respectivamente através das equações:

$$
\begin{aligned}
& \mathrm{X}=\frac{\mathrm{n} \% \text { de frutos }}{\mathrm{n} 9 \text { de flores }} \times 100 \\
& Y=\text { produção/planta } X \text { n } \bullet \text { de plantas/ha }
\end{aligned}
$$

$\left({ }^{6}\right)$ OJIMA, M. Relatório de atividades e observações durante a bolsa de aperfeiçoamento têcnico em fruticultura no Japão:-... Campinas, Instituto Agronômico, 1965. 108p. - (não publicado) 
o fruto maduro é caracterízado por algumas mudanças na coloração, aumento do teor de açủcares, diminuição da acidez, intensificação no aroma e diminuição da firmeza da polpa, que a torna mais sucosa. Essas mudanças físicas, bioquímicas e fisiológicas são facilmente perceptíveis.

0 pêssego maduro, como orgão de reserva, é - constituído por 85 a 90\% de água, além de sais minerais e outros sintetizados como carboidratos, lipídeos, protídeos, ácidos orgânicos, compostos fenólicos, flavonóides, caro: tenóides e outras substâncias voláteis. 


\subsection{Desenvolvimento do pessegueiro no sistema de pomar COMPACTO}

O sistema de formação de pomares em alta densidade de píantio, vem aos poucos obtendo maior reconhecimento dos fruticultores mais modernizados. Com a adoção desse modelo ultra-especializado de cultivo, espera-se um aproveitamento mais racional da terra, pelo aumento da produção de frutos por área, alēm da redução de mão-de-obra e de outras práticas culturais. Dessa forma, torna-se possível um maior e mais rápido retorno do capital empregado, fator esse fundamental ao progresso de qualquer empreendimento agrícola (BARBOSA et al., 1989a).

A técnica revolucionária de ultra-alta densidadè de plantio está sendo pesquisada em fruticultura, desde o início dos anos 70. Tal sistema foi desenvolvido inicialmente na Inglaterra para a cultura da macieira (HUDSON, 1971; LUCKWILL \& CHILD, 1973), e, posteriormente transportado com sucesso para o pessegueiro em värias regiões do mundo (EREZ, 1976; 1978; 1982; 1985; BARGIONI et al., 1979; =GUERRIEIRO et al., 1980; COUVILLON, 1979; 1984; SANSAVINI, 1981; CAMPO-DALL'ORTO, 1984a). Constitui hoje uma das práticas culturais de maior repercussão e importância na persicultura mundial, e em especial nas regiões de clima subtropical. 


\subsubsection{A fitotecnia e a ecofisiologia}

A compactação extrema de pomares de pessegueiro pode ser caracterizada pelos seguintes conceitos fitotécnicos: a) o espaçamento mínimo entre as plantas e as linhas é aquele agronomicamente mais suportável pelo cultivar, sem que no entanto, haja competição prejudicial entre os indivíduos; b) as mudas podem ser formadas no pröprio local de cultivo definitivo; c) dois metros e meio de altura das plantas, deve ser o porte próximo do ideal, para uma produção de frutos; d) a poda drástica anual constitui a maneira mais prática de manter as árvores sempre pequenas; e) as operações no pomar podem ser total ou parcialmente mecanizadas, reduzindo o trabalho manual; f) as produções anuais de frutos resulta de uma copa totalmente renovada, g) a luminosidade incidente no interior do pomar é muito similar em todos os anos, devido ao regime de desenvolvimento da copa; h) o- emprego de pesticidas e adubos torna-se mais eficiente; e 1) o sombreamento causado pelas copas das plantas ajuda a manter a umidade do solo e a diminuir a presença de ervas invasoras (CAMPO-DALL-ORTO et al., 1984a, 1984b; EREZ, 1985).

No entanto, para se adotar a maior densidade de plantio é fundamental um conhecimento prévio do nível de competição biológica que o sistema pode proporcionar às plantas. Sem um estudo preliminar detalhado da época da poda, da necessidade individual em relação à luz, água, nu- 
trientes e outros fatores, o pomar pode não atingir $\circ$ grau de uniformidade desejável, e assim desvirtuar-se do objeto principal, que é o aumento da produção por unidade de área.

Os fatores que implicam na competição das plantas, podem ser eliminados na escolha do cultivar copa ou porta-enxerto (características vegetativas e reprodutivas), no delineamento do pomar (clima e solo predominantes, espaçamento e condução), e nos tratos culturais (poda, irrigação, fitossanidade, capinas) (7). Pela TABELA 2 se pode visualizar a variação do número de pessegueiros/ha, de acordo com as diferentes combinações de espaçamentos.

Ao aperfeiçoamento da técnica de condução dos pomares em ultra-alta densidade de plantio, pesquisas complementares devem ainda merecer especial atenção.

$\mathrm{Na}$ ärea de melhoramento genētico, por exemplo, devem ser pesquisados genótipos rústicos de melhor adaptação ao sistema; há carência tanto de cultivares altamente precoces como porta-enxertos adequados.

Nesse aspecto, a Seção de Fruticultura de Climą Temperado, do IAC, vem atribuindo enfoque especial às. ( ${ }^{7}$ ) BARBOSA, W.; CAMPO-DALL'ORTO, F.A. \& OJIMA, M. Conhecimentos, básicos indispensáveis à implantação de uma cultura frutícola comercial. Campinas, Instituto Agronômico, 1987, 60p. (não publicado) 


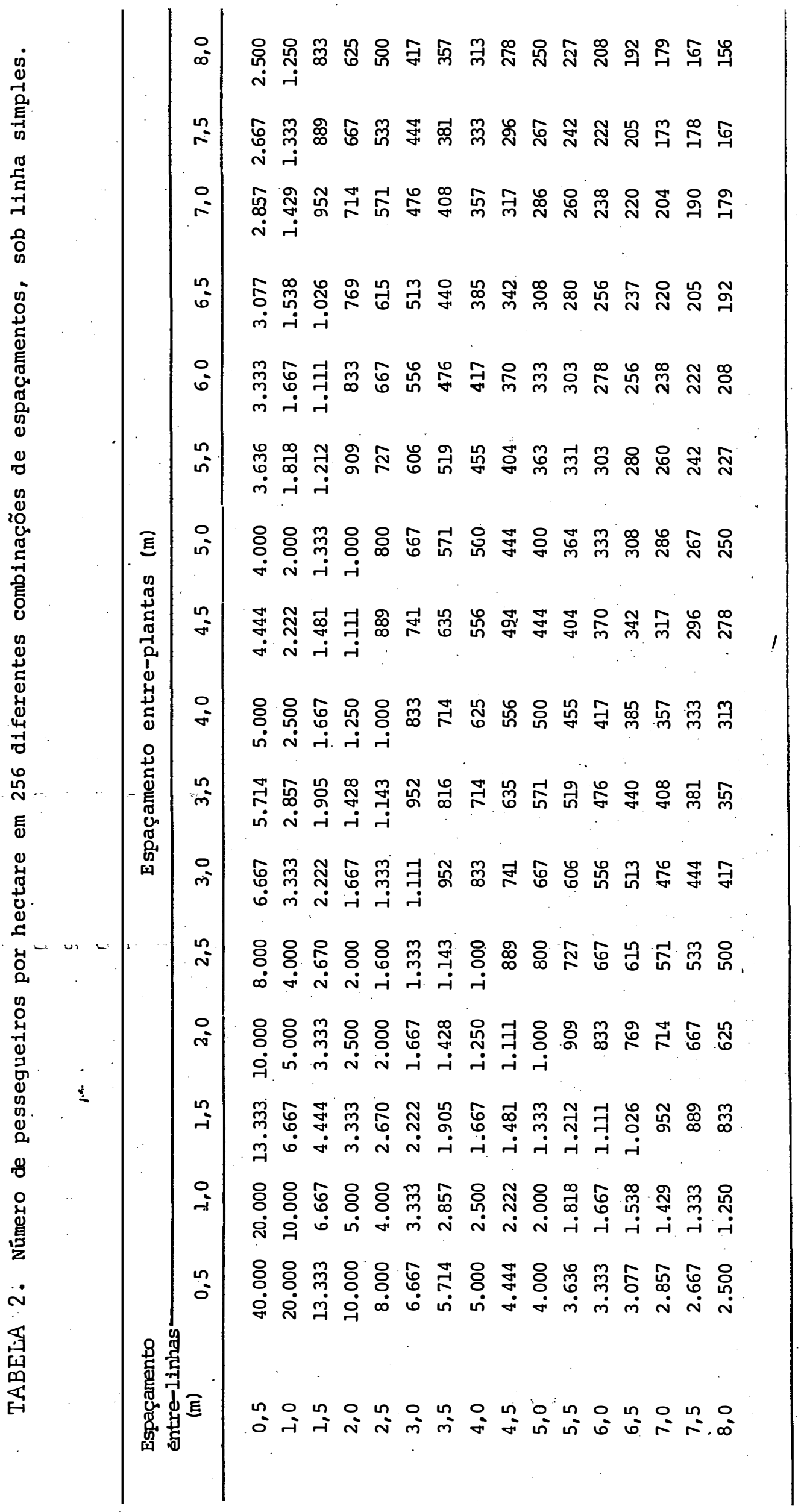


pesquisas que visam a obtenção de cultivares super precoces, produtivos e compativeis com esse sistema de cultivo.

Pesquisou-se recentemente o comportamento de 29 seleções de pessegueiros em ultra-alta densidade de plantio, com poda drástica anual de renovação de copa. . Os espaçamentos adotados, de $3,0 \times 0,5 \times 0,5 \mathrm{~m}\left(0,875 \mathrm{~m}^{2} / \mathrm{planta}\right)$ em fileiras duplas, e de $3,0 \times 0,5 \mathrm{~m}\left(1,500 \mathrm{~m}^{2} / \mathrm{planta}\right)$ em fileiras simples, corresponderam às densidades de 11.428 e 6.666 plantas por hectare, respectivamente. Nessas densidades populacionais, não se evidenciaram nitidamente os efeitos negativos de competição biológica entre os'diferentes indivíduos. Esse fato foi comprovado pelas altas produções das seleções pesquisadas. Dos cultivares experimentados, elegeram-se a princípio cerca de dez mais promissores, que se destacaram pela precocidade, alta produtividade de frutos e razoável desenvolvimento vegetativo: 'Flordaprince', 'Maraviilha', 'Jöia-l', 'Jóia-2', 'Jóia-4', 'Dourado-1', 'Ouromel-2', 'Ouromel-3', 'Doçura-2' e IAC 4974-10. As suas produções varïaram na faixa de 25 a 35 toneladas/hectare, quando em fileiras duplas, e de 20 is 30 ton/ha, em fileiras simples. As demais seleções foram consideradas a princípio não adequadas ao sistema de poda drástica anual, pois, com ciclo de maturação precoce-mediana, não conseguiram recuperar em tempo hábil, nova copa fisiologicamente matura. A produção mêdia, obtida no primeiro ano de frutificação, foi equivalente à de um pomar com idade de seis a oito anos de idade, conduzido convencionalmente no 
espaçamento tradicional $(7 \times 5 \mathrm{~m})$ (CAMPO-DALL'ORTO et al., 1984a).

Apesar dos resultados promissores obtidos nas condições climāticas subtropicais paulistas, acredita-se que com a seleção de novos cultivares mais precoces (ciclos de 70 a 80 dias da floração à maturação), os tratos culturais sejam ainda mais facilitados e o sistema definitivamente viabilizado. Além da maior precocidade, os materiais devem também apresentar rusticidade em seus häbitos vegetativos e reprodutivos, assim como completa adaptação ao clima de características subtropical-tropicais (BARBOSA el al., 1989a).

A arquitetura da planta nesse sistema, constitui outro fator relevante na seleção de genótipos. ideotípicos ( ${ }^{(8)}$; assim, quanto menor o ângulo dos ramos vegetativos, maior poderá ser o aproveitamento de energia radiante disponivel (FERRAZ, 1985). O auto-sombreamento completo da parte inferior da copa não é interessante para o pessegueiro, a exemplo do que ocorre com a maioria dos cultivos perenes. Apesar das adaptações fotocromāticas das folhas sombreadis (MAGALHÃES, 1979), o pessegueiro se enfraqueçe diminuindo o número de ramos internos de produção. Dessa forma, a maioria dos orgãos intra-copa, torna-se bastante dependen-

( $\left.{ }^{8}\right)$ Genótipos ideotípicos são aqueles selecionados para uma atividade fitossintética superior, sob reduzido espaçamento de plantio. 
te dos fotossintetizados das partes mais externas da planta. Outras características para melhor adaptação ao sistema, devem ser tạmbém consideradas: maior capacidade e eficiência na absorção e aproveitamento de água e nutrientes do solo, e maior resistência varietal às pragas e doenças.

Em relação ao efeito negativo do auto-sombreamento, TOMBESI \& BELLEGGIA (1986) relatam que pessegueiros 'Flavorcrest', cultivados no espaçamento de 4,5×3,5m (635 pl/ha), sob condução de líder central, apresentarạm comportamento distinto quando submetidos ou não a podas de verão. Nas plantas assim conduzidas, dotadas de copas menos compactas, houve maior diferenciação floral e os frutos produzidos foram maiores e de melhor colorido e sabor. As copas adensadas, mostraram-se bastante ineficientes e irregulares na formação de gemas de flores, devido à deficiente penetração da luz.

0 sistema de pessegais compactos, com consequlente emprego da poda drástica para renovação da copa, parece ter sérias limitações em muitas regiões do globo, onde o outono e inverno são estações impeditivas do desenvolvi$+$ mento vegetativo. Um experimento conduzido em ārea central de Oklahoma, EUA, mostrou que plantas de 'Redhaven' adensadas, diferenciaram um mínimo de gemas florais, aos insignificantes níveis de 5 a 10\%. Alếm desse fato, essas gemas em desenvolvimento, apresentaram atraso de aproximadamente dois meses, em relação à sua época normal de diferenciação. 
Esse mesmo cultivar, quando mantido em densidade e tratos culturais convencionais, produziu normalmente elevado nûmero de flores e frutos por ramo (WARRINER et al., 1985).

0 excessivo vigor vegetativo dos pessegueiros (copa e porta-enxerto), submetidos à poda drástica, constitui outro fator que pode dificultar, em certos casos, o estabelecimento de pomares em ultra-alta densidade. Esse crescimento vigoroso dos ramos pode acarretar uma competição intensa e indesejável com os frutos por água, carboidratos, minerais, e reguladores de crescimento, o que consequlentemente causa uma produção de baixa qualidade. ' Para solucionar esse problema, pode lançar-se mão de porta-enxertos ananicantes ou mesmo de produtos químicos, como certos reguladores de crescimento, que bloqueiam de certo modo a síntese do $\mathrm{GA}_{3}$ e AIA. Esses dois métodos paliativos fazem com que as plantas fiquem menores e mais compactas, e assim, mais compatíveis ao maior adensamento (HANSCHE et al., 1979; EREZ, 1986).

Os retardadores de crescimento como: SADH, CCC, ETHEPHON, DAMINOZIDE, PACLOBUTRAZOL (PP 333). e FLURPRIMIDOL, podem ser aplicados via foliar (por pulverização) ou radicular (por irrigação). O PACLOBUTRAZOL, o mais efetivo, proporciona resultados positivos quando aplicado ao solo, e principalmente, na primavera, na concentração entre 12,5 a 125 mg/planta (EREZ, 1986); a 2,0 g/planta o efeito ananicante torna-se ainda maior (BLANCO, 1988). Ao ser aplicado 
58.

via foliar, é menos efetivo devido à baixa penetração e à menor translocação do princípio ativo na folha. Esse retardador de crescimento, alëm de controlar o vigor da planta a cerca de $1 / 3$ de seu potencial, faz também com que se aumente o peso individual, a coloração, a firmeza e os sólidos solūveis totais dos frutos (MARINI \& WEFELMEYER, 1985; EREZ, $1986 ;$ BLANCO, 1988 ).

\section{Outro fator importante a se considerar}

no sistema de ultra-alta densidade, cọstitui-se nạ necessidade de utilização de maior número de mudas por unidade de área: Pelo método tradicional de formação de mudas de pêssego, necessita-se da utilização de porta-enxertos e a posterior realização de enxertias com os cultivares copas desejados. Para facilitar a multiplicação em larga escala, o método de enraizamento de estacas lenhosas ou semi-lenhosas, ou mesmo a micropropagação, em condições especiais, podem ser adotadas com vantagem.

No caso da formação de mudas, via-estacas, essas são colhidas preferencialmente no outono e induzidas ao enraizamento pelo tratamento com o ácido indolbutírico (IBA). As estacas enraizadas, podem assim, ser mantidas em viveiros por período determinado ou plantadas diretamente no campo. Essa metodologia reduziria a mão-de-obra, o tempo necessārio à propagação, bem como o custo final das mudas. Além disso, sugere-se que os pessegueiros provenientes de estacas auto enraizadas, possam aproveitar mais efi- 
cientemente os nutrientes minerais do solo. Análises realizadas mostram que à exceção do zinco, todos os nutrientes essenciais apresentaram-se em doses superiores ou similares às plantas propagadas por enxertia (COUVILLON, 1982).

Os pessegueiros e nectarineiras como o: 'Maravilha', 'Sunlite', 'Desert Gold', 'Earlingrande' (EREZ \& YABLOWITZ, 1981; EREZ, 1984), 'Redhaven', 'Sungold' (COUVILLON \& EREZ, 1980), 'Diamante' (FACHINELLO et al., 1982), 'Sunred' (BELLINI et al., 1984), têm sido propagados com relativo sucesso sob o processo de auto-enraizamento; maioria deles são cultivados em escala comercial.

Entretanto, certas desvantagens, a exemplo da presença de nematóides causadores de galhas em raízes, podem, em alguns casos, tornar-se mais acentuados com 0 auto-enraizamento, o que inviabilizaria esse processo de multiplicação.

........ Com o aumento da densidade de plantio e a consequlente mudança nas dimensões da planta, não devem ser desprezados os efeitos do regime e da qualidade de luz incidenţe no pessegal (JACKSON, 1980; AVIDAN \& EREZ, 1986). Como a quantidade de fotossintetizados obtidas pela planta è influenciada, em última análise, pela intensidade e qualidade da luz incidente (HALL \& RAO, 1980), a disposição, direção de plantio e o manejo da copa, devem se constituir em fundamentos essenciais à implantação da ultra-alta densidade. 
Para adequada interceptação e distribuição da radiação luminosa pela copa, ela deve estar livremente exposta a várias direções. Ao que parece, o sentido de plantio Norte-Sul é o que proporciona o melhor padrão de interceptação da luz. Sob essa orientação, são obtidos maiores produções e frutos de melhor qualidade. Para determinadas densidades, as plantas se desenvolvem melhor quando dispostas em renque duplo ou em triangulação (JACKSON, 1980), pela sua melhor disposição no espaço útil.

As práticas culturais, como certas podas de verão (MILLER, 1.9.8.7), irrigação controlada (CHALMERS et al., 1981) e mesmo o desfolhamento parcial das plantas, normalmente tornam a copa bem mais eficiente na utilização da luz, durante o período de maior compactação foliar. 


\section{MATERIAL E MËTODOS}

\subsection{MATERIAL VEgETAL}

Utilizaram-se ao desenvolvimento. experimental, dois novos pessegueiros do IAC: 'Tropical' (IAC P:180-1) e 'Aurora-2' (IAC P 2680-14).

'TROPICAL'. - trata-se de um pêssego "de mesa", de maturação bem precoce, com ciclo de florada àcolheita de $80 \pm 5$ dias. Apresenta frutos médios, 85 gramas, globosos, sem bico e bastante avermelhados externamente, próximo a $90 \%$ da superfície total. A polpa é amarela e sucosa; ocaroço é solto; o sabor é do tipo doce acidulado bem equilibrado, com ${ }^{\circ}$ Brix 16,0 e pH 4,2. A planta apresenta ramificação e enfolhamento em intensidade mëdia, característica de cultivạires precoces, porém floresce e frutifica abundantemente. Sua descendência ê: polinização aberta de IAC P 371-2 ('Tu-

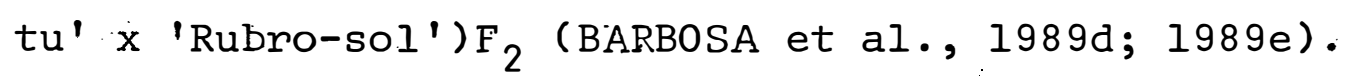

'AURORA-2' - ê um pêssego "de mesa", de maturação mediana, com ciclo da florada à colheita de $120 \pm 5$ dias. Seus frutos são grandes, 130 gramas, globoso-oblongos e com pequeno ápice; a coloração de fundo é amarela, porém, predo-. 
mina a vermelha escura intensa, em cerca de $80 \%$ do fruto. A polpa é do tipo "amarela-firme", com leve avermẹlhado próximo ao caroço; o sabor é doce-acidulado fraco, com 4,6 de pH e 12,0 de ${ }^{\circ}$ Brix. A planta 'é bastante vigorosa, com abundante folhagem e ramificação; floresce e frutifica bem todos os anos. Sua descendência é: polinização aberta de 'Ouromel-4' ('Ouromel' $x$ 'Rubro-sol') $F_{2}$ (OJIMA et al., 1989).

\section{3.. 2. LOCALI ZACÅO E ECOLOGIA DA AREA EXPERIMENTAL}

\subsubsection{Local da pesquisa}

A experimentação foì realizada na Estação Experimental de Jundiaí, do Instituto Agronômico de Campinas. Essa Estação possui uma ārea total de 142,8 ha e está situada na região Norte de Jundiaí, aproximadamente com as coordenadas $23^{\circ} 08^{\prime} \mathrm{S}$ e $46^{\circ} 55^{\prime} \mathrm{W}$ e com altitudes que variam de 680 a 760 metros (VALADARES, et al., 1971). 0 experimento foi instalado numa altitude próxima a 700 metros.

\subsubsection{Condị̂̃oes climatoedafológic̣as}

Os dados relativos a precipitação- pluviométrica (mm), temperatura do ar $\left({ }^{\circ} \mathrm{C}\right)$ e insolação (horas), durante o período de execução da pesquisa (1986-87), encontramse nos APENDICES 1 e 2 .

A ảrea possui um clima mesotẻrmico de invverno 
seco (Cwa), comumente chamado de tropical de altitude.

No local do experimento o solo é raso, pouco desenvolvido e bem drenado, identificado como unidade Currupira-modal (Cur), pertencente ao grande grupo Litosol, fase substrato filito-xisto (SERVIÇO NACIONAL DE PESQUISAS AGRONÔMICAS, 1960; VALADARES et·al., 1971).

\subsection{PROCEDIMENTO EXPERIMENTAL}

3.3.1. Germinação das sementes e formação dos porta-enxertos

As sementes (caroços) do cultivar porta-enxerto Okinawa, considerado resistente a nematóides causadores de galha (RIGITANO et al., 1975; MENTEN et al., . 1977), foram obtidas de frutos maduros, colhidos da Estação Experimental de Jundiai, em outubro de 1984. No laboratörio da Seção de Fruticultura de Clima Temperado (IAC), os cařoços recêm-extraídos dos frutos foram quebrados e as amêndoas estratificadas em geladeira $\left(5-10^{\circ} \mathrm{C}\right)$, em algodãoumidecido; por 40 dịas (王 1000 horas de frio) (BARBOSA et al., 1986c; BARBOSA et al., 1987a; 1987b).

As sementès (amêndoas) após germinadase apresentando uma radícula com cerca de $10 \mathrm{~mm}$ de comprimento, foram semeadas em sacos plásticos do tipo para mudas de café (Il $\times 17 \mathrm{~cm})$, contendo terra enriquecida com torta de mamona 
e adubos minerais. Os recipientes foram mantidos em ambiente de ripado, com $50 \%$ de luminosidade, à normal emergência e desenvolvimento inicial das plântulas.

Após um período de seis meses de permanência no ripado, os porta-enxertos mais vigorosos foram transplantados ao campo (maio/85), em local definitivo, para continuar o desenvolvimento e receber a enxertia.

3.3.2. Plantio dos porta-enxertos, enxerntia e tratos culturais

Os porta-enxertos foram plantados em três linhas paralelas de 96.m cada, sob alta densidade, no espaçamento de $3,0 \times 2,0 \mathrm{~m}$ ( 1.667 plantas por hectare). Em fins de dezembro. de 1985, enxertaram-se na linha central vinte e quatro plantas em sequência com o 'Tropical' e outras tantas com - 'Aurora-2', ocupando assim uma área de $312 \mathrm{~m}^{2}\left(6,0 \mathrm{~m}^{2} / \mathrm{plan}-\right.$ ta). Nas linhas laterais, fêz-se concomitantemente a enxertia com os mesmos cultivares, para constituição das plantas bordaduras. A enxertia, por borbulhia do tipo "chapinha's, foi efetuada a $10 \mathrm{~cm}$ da superfície do solo.'Após 20 dias da enxertia, realizou-se a desponta da parte apical dos porta-enxertos, para possibilitar o normal desenvolvimento das borbulhas (gemas) enxertadas. 0 pegamento da enxertia foi de 100\%. (área total do experimento $=936 \mathrm{~m}^{2}$ ). 
Os tratos culturais rotineiros do pessegueir.o, como: capina, desbrota, adubação, pulverização e outros, foram baseados nas informações do Boletim 200 do IAC (CAMPINAS, 1987) e adaptados ao sistema de alta densidade de plantio (CAMPO-DALL'ORTO et al., 1984a).

Cerca de nove meses da enxertia (setembro/86) iniciou-se a realização das podas drásticas mensais.

\subsection{3. Épocas de podas drásticas}

0 delineamento experimental adotado foi 0 inteiramente casualizado, composto de 4 tratamentos e 6 repetições :

Tratamento 1 - Controle;
Tratamento 2 - Poda drástica em 30.09.86;
Tratamento 3 - Poda drāstica em 30.10.86;
Tratámento 4 - Poda drästica em 30.11.86.
As plantas de. 'Tropical e 'Aurora-2' (do ensaio e bordaduras) foram podadas com o auxilio de serrotes a uma altura de $10 \mathrm{~cm}$ acima do ponto de inserção do enxerto. Proporcionaram-se às respectivas bordaduras as mesmas épocas e tipos de podas.

Para evitar queimaduras dos troncos das plantas recém-podadas, devido a forte insolação de verão, esses foram protegidos com os próprios ramos das copas decepadas. 
Um pincelamento dos troncos com a mistura de cal, cobre e sal foi realizado antes da poda.

As plantas controles receberam, no inverno de 1986, poda leve de limpeza e encurtamento de cerca de $25 \%$ dos ramos.

\subsubsection{Desenvolvimento vegetativo}

Os protocolos de desenvolvimento dos pessegueiros foram realizados quinzenalmente nos primeiros dois meses da poda. Apōs esse períiodo as observações foram mensais (APÊNDICES $3,4,5$ e 6 ).

As desbrotas foram realizadas cerca de 20 dias das respectivas podas, deixando-se cinco brotos por tronco, para a formação da nova copa.

Em maio-junho de 1987 foi controlada a altura das plantas, o nümero de nỏs por metro de ramo (m.r.) e a quantidade de gemas por nó de ramo (n.r.). Para cada tratamento e repetição mediu-se a altura de cinco ramos principais por planta. No controle da quantidade de nós e de gemas foram medidos aleatoriamente seis metros : de ramo:" por planta.

3.3.4.1. Coleta e preparo histológico das gemas

A coleta das gemas, de cada material, foi rẹ: 
lizada mensalmente a partir do 30 ! dia da poda. Foram feitas no total: 9 , 8 e 7 coletas de gemas para as plantas podadas em: $30 / 09,30 / 10$ e 30/11/86, respectivamente. As gemas foram coletadas até junho de 1987, próximo a época do início da floração.

Para cada tratamento e repetição coletaram-se, ao acaso, três ramos, os quais foram levados ao laboratório da Seção de Fruticultura de Clima Temperado, onde se fez a retirada das gemas de sua porção central ( 4 a 6. por ramo). De cada tratamento coletaram-se mensalmente, de 78 a 108 nós de gemas $^{(9)}$.

As gemas de cada nó, após removidas dos ramos, eram individualizadas e descamadas para a melhor penetração dos agentes histoquímicos.

Os tratamentos preparatörios às observações histológicas constaram das seguintes fases:

- Fixação das gemas por 24 horas em CRAF, constituído de duas soluções aquosas: a) 1\% de ácido crômico, 7\% de ácido acético glacial.e; b) $30 \%$ de formalina, que eram misturadas, em volumes iguais, no momento da operação;

(9) Os ramos adultos do pesseguèiro apresentam por nó, cerca de três gemas, em que, normalmente, as de flancos (laterais) são floríferas e as centrais vegetativas (FIGURA 2). 
68.

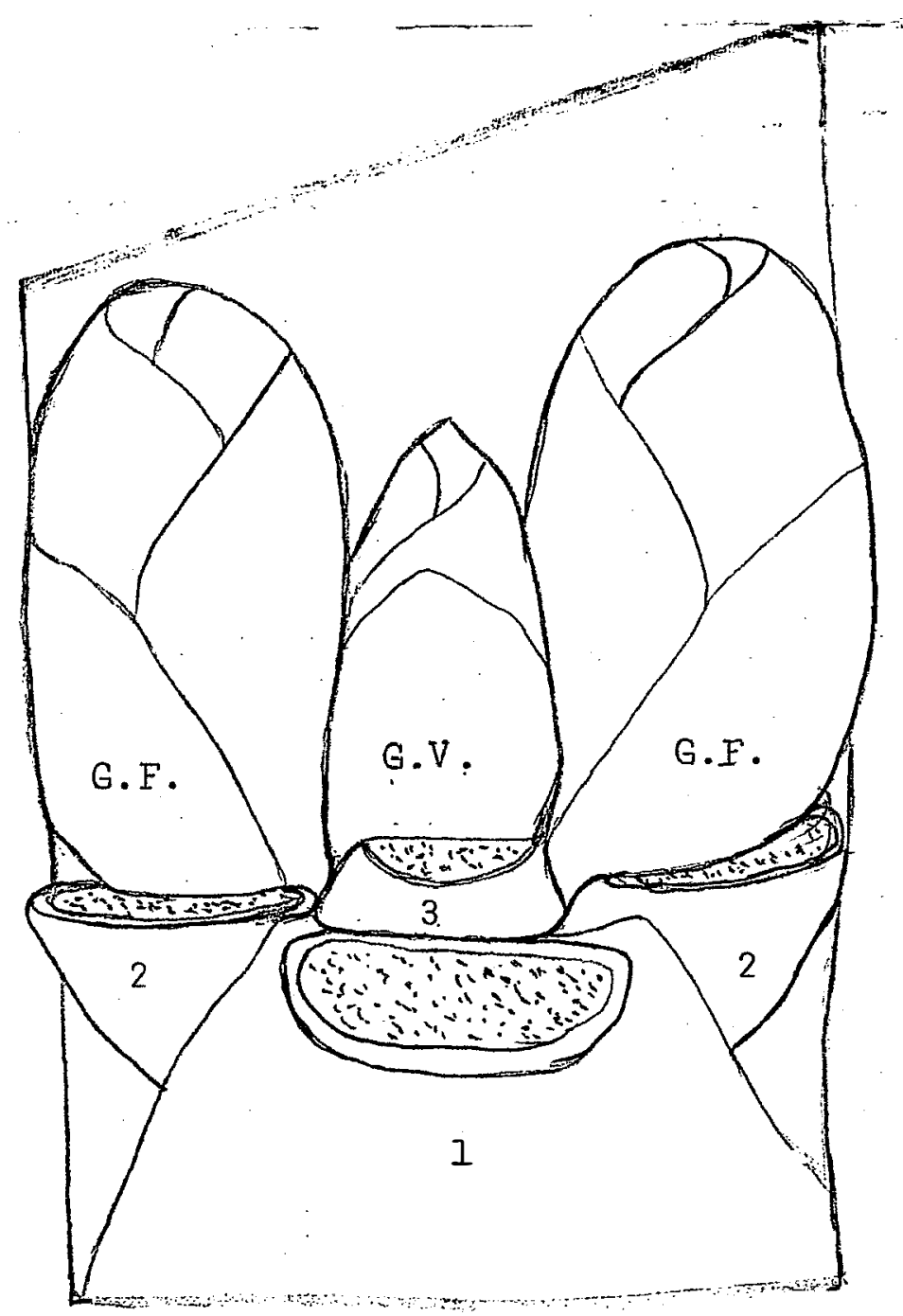

FIGURA 2. Esquema de um nó de gema de pessegueiro. Ao cen$\div \quad$ tro, gema vegetativa (G.V.), de formato e aspecto distintos das gemas de flor (G.F.) nos flancos. Inserção das folhas: 1 = primária, 2 - secundāria; 3 = terciāria. 
- Lavagem do material, em água corrente, durante 30 minutos;

- Desidratação por 30 minutos nas séries de álcoois a 30,50 e $70 \%$; armazenamento do material, neste último, por duas semanas.

- Retirada (em microscópio estereoscópico) das escamas excedentes e de alguns primórdios foliares das gemas, e nova desidratação por 12 horas, numa série de álcoois a 70,96 e $100 \%$;

- Clareamento do material por 4 horas pela imersão em tolueno;

- Infiltração nas gemas de uma mistura de parafina e tolueno, a $60^{\circ} \mathrm{C}$, durante 4 horas;

- Inclusão em parafina pura, a $60^{\circ} \mathrm{C}$, durante 24 horas;

- Montagem dos blocos de parafina e cortes longitudinais das gemas;: :

- Colagem à quente dos cortes nas lâminas (25 x 75mm), com uma solução de albumina (clara de ovo), glicerina - e salicilato de sódio, e armazenagem do material em ambiente seco por 10 dias;

- Desparafinagem dos cortes em banhos de 5 minutos cada, em álcool a 100\% (2 vezes), 90, 70, 50 e 30\% (1 vez), seguidos de 4 lavagens de 10 minutos :em água destilada; 
- Passagem do material no alúmen de ferro a 4\% por 2 horas, seguidas de 4 lavagens de 5 minutos em água destilada;

- Coloração do material em solução aquosa de hematoxilina a $0,5 \%$ durante 20 horas, seguidos de 3 . lavagens de 10 minutos em água destilada;

- Diferenciação em alúmen de ferro a 2\%, ao microscópio, durante 15. a 20 minutos (variävel), seguidos de quatro lavagens de cinco minutos cada, em água destilada;

- Desidratação do material com banhos de álcoois a 30 , 50,70 e $90 \%$ (I vez) e 100\% (2 vezes) por 5 minutos;

- Passagem ao xilol em 2 banhos de 5 minutos cada; e

- Proteção dos cortes coloridos, pela montagem das lamínulas (25.x 40mm) com bảisamo-de-Canadá e armazenagem por 30 dias em ambiente seco.

Devidamente preparadas as lâminas permanentes, os cortes eram observados em microscỏpio. OLYMPUS CBA; equipadb com apare lho. de fotomicrografia. A evolução... ontogenética das gemas foi avaliada de acordo com as respectivas épocas de poda drảstica. A documentação fotomicrográfica foi realizada uti-lizando-se filmes Kodacolor e Neopan de ASA 100 , com 1 segundo de exposição e luminosidade sete.

A presente metodologia histológica foi adap- 
tada dos trabalhos de JOHANSEN (1940), MEDINA (1964) e MARTINEZ-TELLEZ (1981).

\subsubsection{Cultura de meristema in vitro}

Com o objetivo de se conhecer a época aproximada da indução floral em pessegueiro, nas condições ambientais do planalto paulista, foram cultivados in vitro meristemas de gemas axilares de 'Tropical' (plantas controles). Segundo a literatura, o meristema das gemas do pessegueiro uma vez induzido e diferenciado em botão floral, não sofre mais desdiferenciação.

As gemas, da porção central dos ramos, foram coletadas de forma aleatốria e de toda a superfície da copa. As coletas foram realizadas em quatro épocas, nos finais dos meses de: novembro, dezembro, janeiro e fevereiro. Procurou-se coletar, cerca de 100 gemas de cada uma das épocas referidas.

No laboratório, as gemas foram dissecadas, em microscōpio estereoscőpico (Wild), e os meristemas inocula-

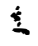

dos assepticamente (em câmara de fluxo laminar Veco) no meio de cultura adequado ao sẹ crescimento. A metodologia do preparo do meio de cultura e dos meristemas, e do cultivo destes, foi baseada em BARBOSA et al., (1986b; 1986c), que micropropagaram, com sucesso, diversos cultivares de macieira. 
Os meristemas após inoculação in vitro, foram mantidos em sala de luz ${ }^{(10)}$, com fotoperiodo de 13 horas e temperaturà de $25^{\circ} \mathrm{C} \pm 2$, "Após cerca de 30 dias de cultivo foi possível a avaliação do experimento.

3.3.4.3. Quebra-de-endodormência das gemas, floração e palinologia

o tratamento químico desfolhante das plantas à quebra-de-endodormência foi efëtuado em 29 de maio de 1987, através de pulverịação com Dinoseb (dinitro-orto-butilfenol) a $1 \%$, e óleo mineral a $2 \%$.

$\mathrm{Na}$ época de floração das plantas, determinou-se a quantidade de gemas floríferas e.vegetativas por nó e por centímetro de ramo..... Controlaram-se 100 nós de gemas, em : :... cinico metros de ramo por planta.

Para verificação palinológica, procurou-se coletar por tratamento e cultivaŕ, 20 botões florais no estádio "D" (balão). No laboratório, avaliou-se o número de anteras por flor, grãos de pólen por antera e a germinação polínica in vitro.

Para o controle do número de anteras por flor,

(10) Trata-se de uma sala equipada com lâmpadas de qualidade luminosa apropriada ao cultivo de explantes in vitro. 
abriram-se os botões florais e com o auxílio de uma pinça, essas foram retiradas e contadas.

Para cada tratamento e cultivar foram separadas, ao acaso, duas amostras de 100 anteras. As anteras da primeira amostra, destinada à contagem dos grãos de pólen, foram colocàdas em beakers de $5 \mathrm{ml}$ durante três dias, a uma temperatura variāvel entre 25 a $30^{\circ} \mathrm{C}$; após esse período (com as anteras já deiscentes), adicionou-se $1 \mathrm{ml}$ de ácido lático visando a homogeneização da suspensão.' 'Da segunda amostra, destinada aos testes de germinação do pólen in vitro, as anteras foram colocadas em placas de Petri, revestidas com papel filtro e expostas à luz artificial, sob temperatura de $28 \pm 2^{\circ} \mathrm{C}$, durante seis horas, para propiciar sua rápida deiscência.

A metodologia de contagem do pōlen foi baseada em KNOWLTON (1935), que utilizando um hemocitômetro calculou a quantidade de grãos existente numa antera de maciei-. ra. No presente trabalho, utilizou-se a câmara de NEUBAWER: uma gota da suspensão de pólen, em ácido lātico, devidamente homęgenizada foi colocada solbre a lâmina; as determinações. foram efetuadas-em microscópio, com um aumento de 100x.

Para cada amostra foram feitas quatro lâminas, totalizando oito repetições, pois cada lâmina contêm duas câmaras de contagem. A fórmula empregada na contagem do pólen foi a seguinte: 
Grãos de pólen/antera $=\frac{x \cdot 10 \cdot 1000}{.4 \cdot 100}$, onde:

$x$ = soma dos grãos de pólen contados na câmara;

$10=$ volume da câmara $\left(0,1 \mathrm{~mm}^{3}\right)$;

1000 = volume do ácido lâtico (lml);

4 = número de quadrados angulares contados na câmara; e,

100 = nưmero de anteras da suspensão.

0 meio de cultura adotado para a germinação dos grãos de pólen, foi constituído de solução salina de MURASHIGE \& SKOOG (1962), acrescida de sacarose a 5\% e agar a $0,6 \% ; 0 \mathrm{pH}$ da solução foi elevado a 6,0 (KOH-0,IN). Esse meio, era distribuído a quente nas lâminas, no volume de $2 \mathrm{ml}$ cada; cerca de $3 / 4$ das lâminas eram cobertas pelo "meio".

Apôs a solidificação do "meio", os grãos de pólen enam polvilhados nas lâminas, com o auxílio de um pequeno pincel; essas eram mantidas em ambiente de sala de luz a $28 \pm 2^{\circ} \mathrm{C}$, por duas horas. Em seguida, as lâminas eram levadas ao microscópio para a contagem dos grãos germinados.

3.3.4.4. Frutificação efetiva, ciclo de crescimento dos frutos e produção

0 controle do pegamento dos frutos de 'Tropical' e 'Aurora-2' foi realizado "pela contagem do núméró de 
flores recém-abertas existentes nos ramos. Após a respectiva anotação desse número em etiquetas, estas eram penduradas na base dos ramos. Para cada tratamento e repetição controlaram-se 12 ramos floríferos. 0 nümero de flores controlado por planta variou de 60 a 140 , dependendo do tratamento.

Cerca de 35 dias do controle das flores,através do número de frutinhos remanescentes nos ramos, estabeleceram-se os Indices de frutificação efetiva das plantas. 0 raleio dos frutos excedentes foi efetuado apōs ' 45 'dias' da floração; procurou-se manter, quando possivel, de dois a cinco frutos por ramo.

o ciclo de crescimento dos frutos foi acompanhado em todas as plantas do experimento. Para tanto, anotaram-se nas mesmas etiquetas de controle de frutificação, os dias das plenas florações. O nümero de dias, desde a floração até a maturação dos frutos, era estabelecido na ocasião das respectivas colheitas.

A quantidade e o peso dos frutos maduros foram controlados em laboratório, assim que colhidos das plantas Foram determinados os picos de colheitas e as "a produrções individuais dos pessegueiros.

Para 'Tröpical' (plantas extra-ensaio), caracterizaram-se, ainda, os respectivos estádios de crescimento dos frutos. Esses estádios aḅrangem o período desde a florada atê a completa maturação dos frutos. Procurou-se 
manter, a essas observações, cerca de dois frutos por ramo. Para tanto, a cada dez dias, os frutos eram colhidos, analisados e seu peso e volume controlados.

\subsubsection{Anālise Estatística}

Foi efetuado análise de variância e teste de Tukey ( $5 \%$ ) para os seguintes dados: altura dos ramos, número de nós (de gemas) por metro de ramo; porcentagem de frutificação efetiva; número de frutos por metro de ramo e produção de frutos. Aos dados palinológicos foram calculados os intervalos de confiança para a média, ao nível de $95 \%$ de. probabilidade (PIMENTEL-GOMES, 19.84). 


\section{RESULTADOS E DISCUSSÄO}

\subsection{BESENVOLVIMENTO VEgetativo E REPRODUtivo DOS PESSE- gueiros 'Tropical' e 'Aurora-2'}

\subsubsection{Comportamento vegetativo}

Os'pessegueiros 'Tropical' e 'Aurora-2' conduzidos no sistema de pomar compacto, iniciaram a rebrota entre cinco a dez dias após a poda drástica. Os troncos decepados apresentaram uma'profusa emissão de brotos, que.. se originaram de gemas latentes pouco perceptiveis.

As diferentes épocas de poda drástica influenciaram no crescimento inicial dos brotos dos dois cultivares. Constatou-se, através de mensurações mensais, que os melhores indices de crescimento vegetativo ocorreram nas it plantas podadas em 30 de setembro (tratamento 2). Nas podas mais atrasadas, de 30 de outubro (tratamento $\underline{3}$ ) e 30 de novembro (tratamento 4 ), verificou-se uma visível diminuição no desenvolvimento dos ramos. Os maiores índices de desenvolvimento dos pessegueiros ocorreram nos três meses subsequientes às podas (FIGURA 3 e APÊNDICES, 3, 4, 5 e 6), Nesse 


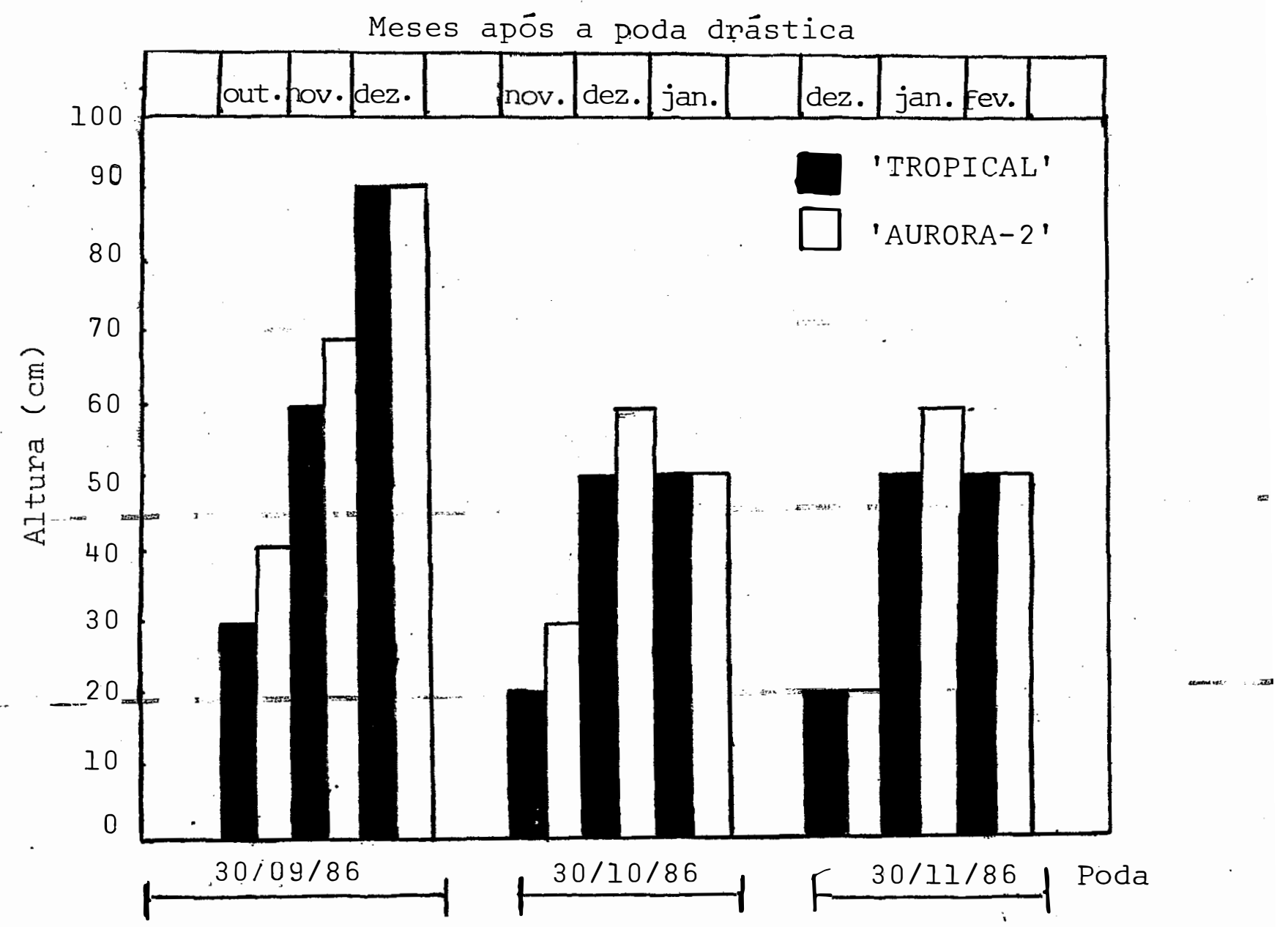

FIGURA 3. Histograma do indice mêdio de crescimento dos ramos dos pessegueiros 'Tropical' e 'Aurora-2', em três meses subsequentes às podas drásticas. 
período as plantas atingiram cerca de $70 \%$ de seu porte final.

0 crescimento exponencial dos pessegueiro procedeu-se de outubro a fevereiro. Esse período de dias bem quentes e longos, è caracterizado como sendo de rápido crescimento e excesso de respiração (FELIPPE, 1979). Logo em seguida a esse período o rítmo das divisões celulares (ll) diminui e causa certa lentidão no desenvolvimento das plantas.

Uma das explicações aceitáveis à essa redução na taxa de crescimento, diz respeito a diminuição do fotoperíodo, que ocorre de modo paulatino a partir do final de dezembro (FIGURA 4). Ao observar o número de horas de brilho solar na látitude $23^{\circ} 30^{\prime} \mathrm{S}$ (São Paulo-SP), verifica-que que há um sensivel aumento a partir de setembrö, devido ao alongamento dos dias. 0 dia mais Iongo do ano, 22 de dezembro, tem duração de 13:30 horas $(h)$, diminuindo gradativamente nos meses seguintes, atē atingir 10:42h, em 22 de junho (FRANCIS, 1972).

Essa diminuição no comprimento dos dias, reduz a taxa fotossintética e estimula nas piantas uma síntese gradatịva de substâncias inibidoras de crescimento (BROWEN. ... \& DERICKSON, 1978; SEARLE, 1965; KENDRICK \& FRANKLAND, 1981); com isso, o balanço hormonal que promove o crescimento é al-

\footnotetext{
(lị) Rítmo de divisão celular é a capacidade de uma célula se dividir, numa determinada unidade de tempo (BANDEL, 1979).
} 


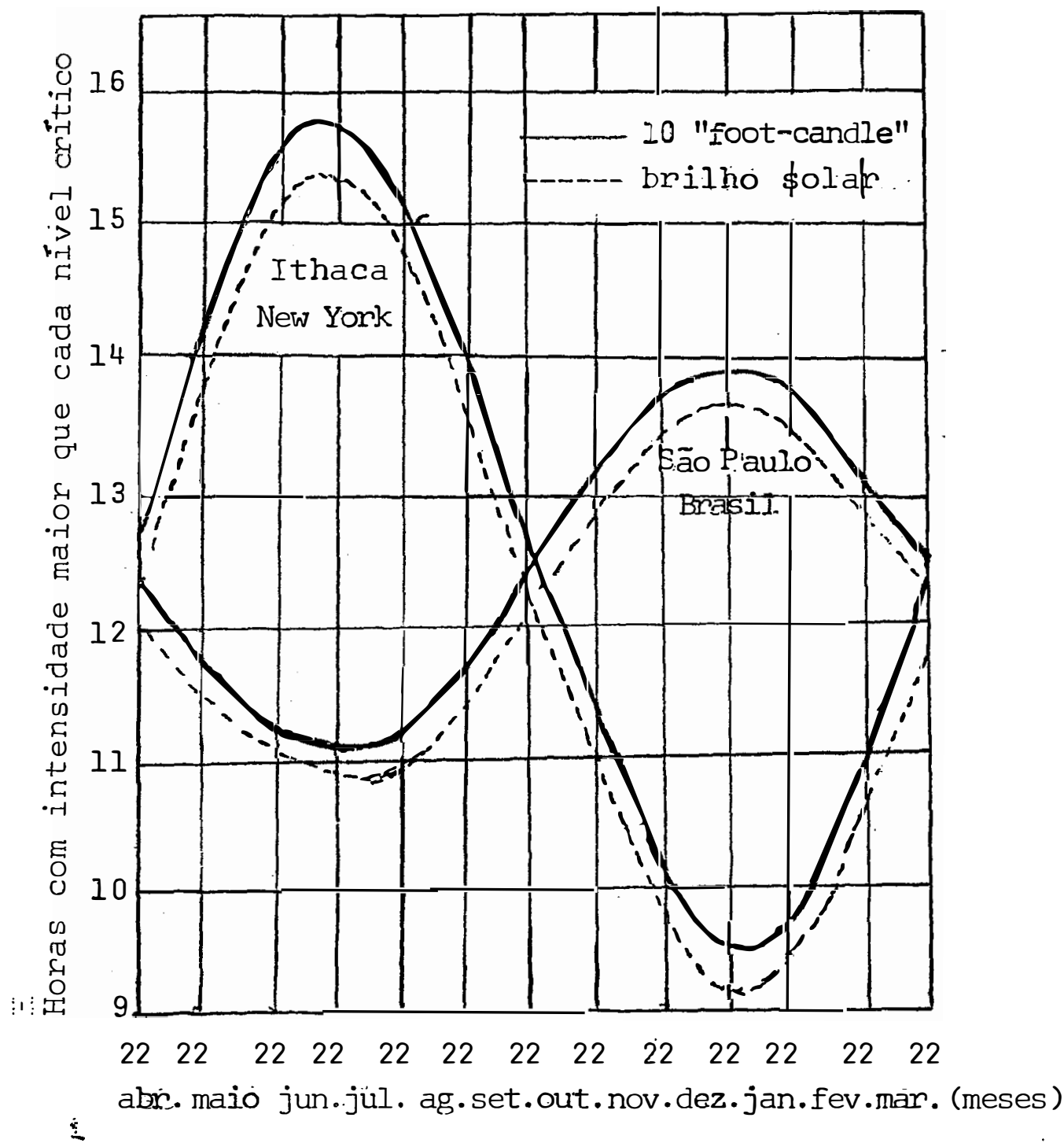

FIGURA 4. Fotoperíodo calculado em função do núnero de horas de brilho solar e das intensidades luminosas superiones ou iguais a '10 "foot-candle" (107,6 lux), em São Paulo, SP (latitude $23^{\mathrm{O}_{30}}$ 'S) e Ithaca, E.U.A. (latitude $\mathrm{N} \quad 42^{\circ} 25^{\prime}$ ) (FRANCIS, 1972). 
terado. Fopoperíodos abaixos de 12 horas diminuiram em cerca de $75 \%$ o crescimento do pessegueiro 'Elberta' (PIRINGER \& DOWNS, 1958).

Os fatores temperatura e precipitação pluviométrica, ao reduzirem seus valores, a partir de fevereiro (FIGURA 5), podem tambëm ter contribuído para a diminuição do crescimento das plantas.

0 cultivar 'Tropical' por ser geneticamente pouco vigoroso e rústico, em relação ao 'Aurora-2', emitiu menos brotações por tronco decepado, os quais apresentaram rítmo de crescimento mais lento.

o rápido crescimento e desenvolvimento dos pessegueiros, verificado principalmente em outubro, novembro e dezembro, parece ter sido decisivo no processo de formação dos nós e das gemas. As gemas axilares, dos pessegueiros podados em 30 de setembro, desenvolveram-se a partir do final de dezembro; em meados a fins de janeiro, essas gemas estavam com o desenvolvimento fenológico máximo.

$\$ \quad$ Entretanto, nas plantas podadas em 30 de outubro e 30 de novembro, as gemas axilares somente se desenvolveram a partir de fevereiro e março, respectivamente. Esse atraso no desenvolvimento prejudicou a uniformidade dos ramos frutíferos, como resultado de uma excessiva falha de gemas ao longo dos mesmos. Esse efeito tornou-se mais evidenté em pessegueiros submetidos a poda de 30 de novembro. 


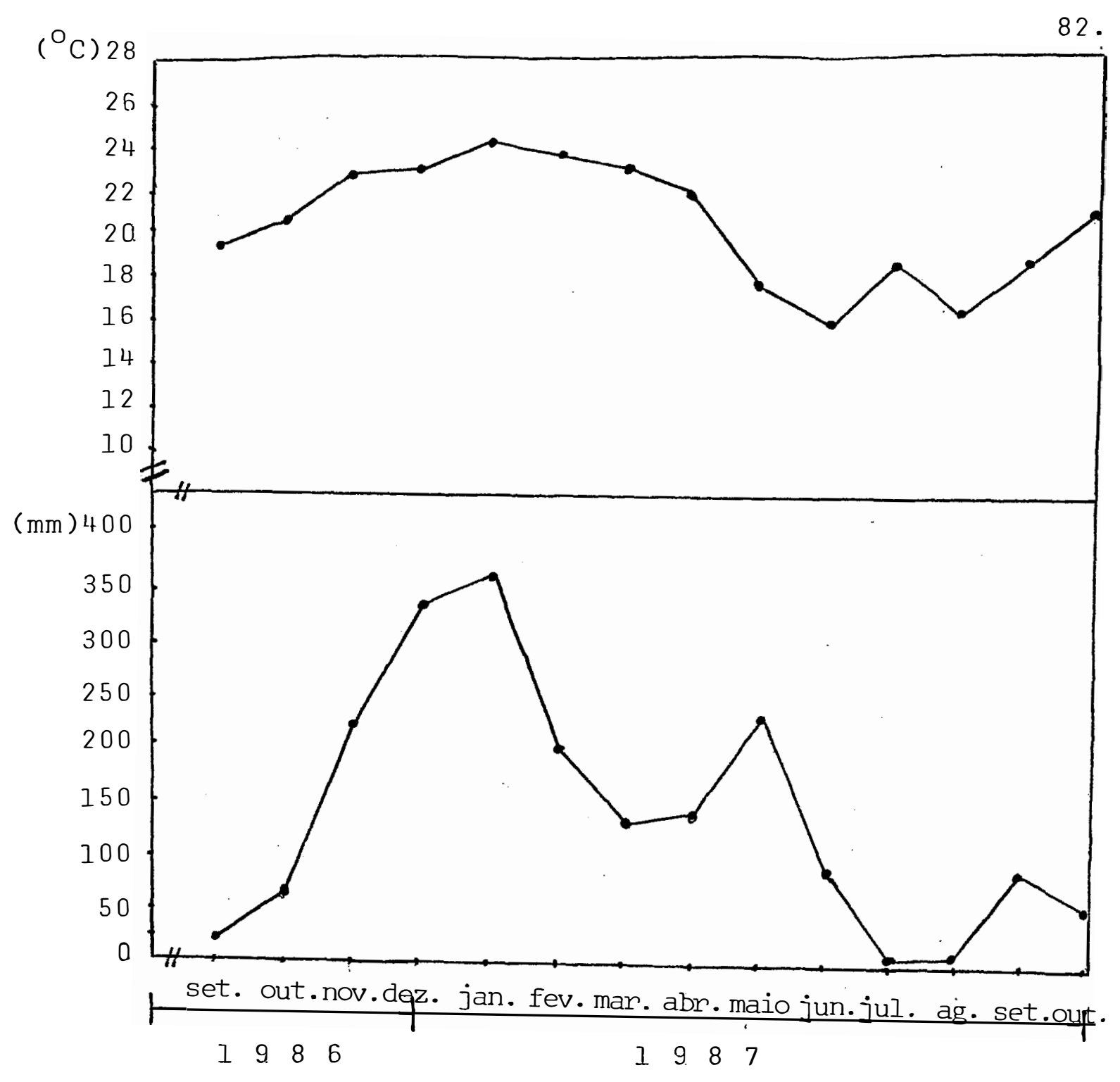

FIGURA 5 . Valores mensais de temperatura média $\left({ }^{\circ} \mathrm{C}\right)$ e precipitação pluviométrica (mon), registrados na Estação Experimental de Jundiaí, SP $\left(23^{\circ} 08^{\prime} \mathrm{S}\right)$, durante.o período de desenvolvimento dos pessegueiros 'Tropical' e 'Aurora-2', em pomar compacto, sob poda drāstica 
A altura média dos ramos dos pessegueiros foi influenciada significativamente $(P<0,01)$, pelas diferentes épocas de poda drástica (TABELA 3).

As plantas do cultivar Tropical, desenvolvidas após a poda de 30 de setembro, paralisaram precocemente o crescimento dos ramos. No início de maio de 1987 , todos os ramos apresentaram uma gema apical do tipo endodormente; o aparecimento desta gema apical, caracteriza o término do ciclo vegetativo. Nessa época, cerca de oito meses após a poda, a altura das plantas deste cultivar atingiu $\bar{x}=2,40$ metros, bem superior a dos demais tratamentos. As plantas provenientes da poda de 30 de outubro, que mediam $\bar{x}=1,46$ metros de altura, após sete meses, ainda apresentavam, cerca de $20 \%$ de seus ramos em crescimento. Enquanto isso, as provenientes da poda de 30 de novembro, após seis meses de desenvolvimento, ainda apresentavam um crescimento vegetativo visível, em cerca de $80 \%$ dos ramos, e altura de $\bar{x}=1,36$ metros. Nesse cultivar não houve diferença significativa entre os tratamentos $\underline{3}$ e $\underline{4}$, na altura média dos ramos, pelo teste de Tukey, ao nível de $5 \%$ de probabilidade (TABELA 3).

0 'Tropical.' apresentou em todos os tratamentos, uma baixa densidade foliar, o que permitiu a difusão de uma razoável quantidade de luz no interior das plantas. A luminosidade, ao atravessar a planta, atingia o solo na projeção da copa, formando inúmeros "sunflecks". Essa arquitetura da planta deve ter contribuído no aumento da taxa 


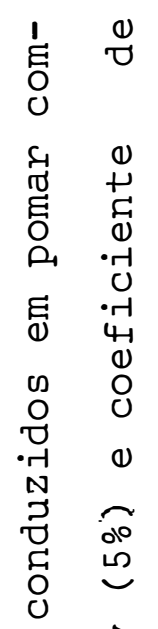

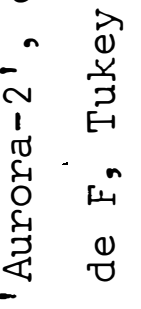

(1) 0

न त

$0>$

मि

द्व

a

(.

()

b) ठั

D

$\stackrel{0}{0} \underset{0}{0}$

ஸे ๘

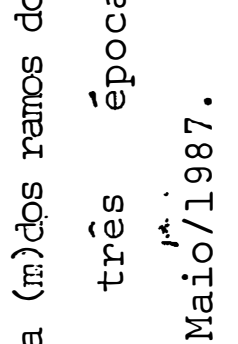

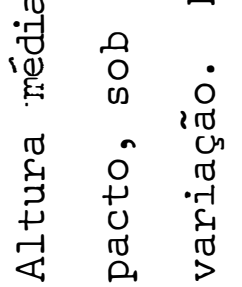

$\dot{m}$

$\stackrel{4}{4}$

$\dot{0} \underset{\cdots}{0}$

जे

m

84.

$\begin{array}{llll}\dot{\Sigma} & 0 & 0 & 0 \\ \dot{a} & 0 & n & n \\ & 0 & n & 0\end{array}$

山i

$\dot{+}$
$\dot{0}$
$\dot{E}$

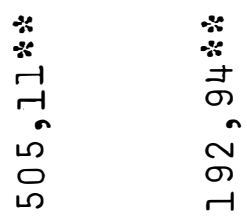

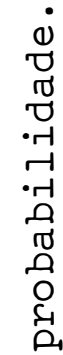

ช

م)

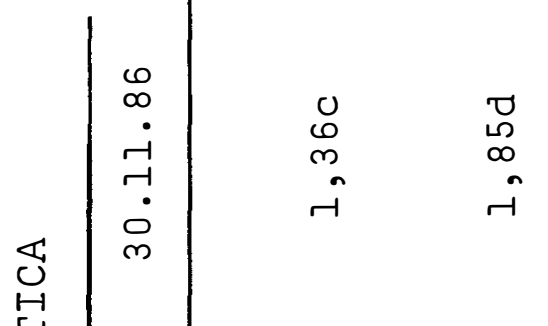

-

竞

임

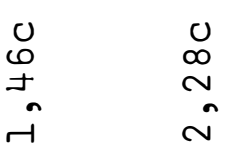

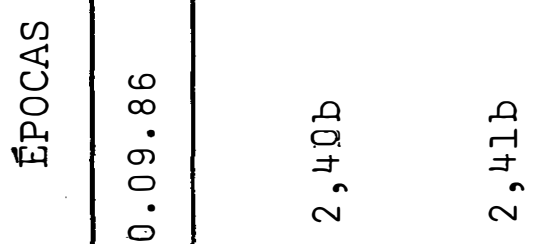

0

苗

.

ค

คُ 2 管

0
0
0
0

ब)

त)

म

이욤ำ

긱

to 0

० 0

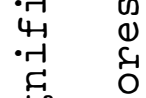

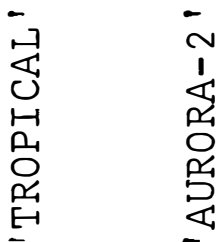

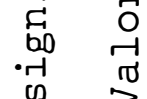

$\%$ 
fotossintética das folhas intra-copa, e conseqüentemente na formação de ramos, externos e internos, de maior diâmetro relativo.

O cultivar Aurora-2 praticamente não paralizou o crescimento dos ramos, como ocorrera com o 'Tropical'. Em final de maio de 1987 os pessegueiros de todos os tratamentos estavam em pleno desenvolvimento; com isso, atingiram alturas sempre maiores. Houve entre os tratamentos deste cultivar, uma diferença altamente significativa $(\mathrm{P}<0,01)$, para a altura média dos ramos. O tratamento de quebra-de-endodormência, com Dinoseb, realizado em 29 de maio de 1987, causou queimaduras apicais de seus ramos vegetativos. Esses ramos, jovens e tenros, não estavam totalmente "endurecidos" e aptos ao referido trato cultural.

$$
\text { Os ramos em desenvolvimento de 'Aurora-2', }
$$
com características de "juvenilidade" (JANICK, 1968 ; ZIMMERMAN, 1972), comprometeram seriamente a reprodução das plantas. Suas gemas ainda jovens, localizadas no terço superịior da copa, não evoluiram à condição reprodutiva, permanecendo a maioria delas no estádio vegetativo.

Un alto índice de área foliar foi verificado em 'Aurora-2'. Isto, aliado à constituição extremamente vigorosa de suas plantas, proporcionou, em época precoce uma competição espacial inter-copas bastante acentuda, resultando na formação de ramos frutíferos finos e longos. 0 auto-sombreamento foi notório, máxime, nos tratamentos $\underline{1}, \underline{2}$ e $\underline{3}$. 
As plantas do tratamento 1 de 'Tropical'

e

'Aurora-2' desenvolveram-se normalmente, atingindo em maio de 1987, uma altura de $\bar{x}=2,86$ e 3,04 metros, respectivamente. Esses pessegueiros, não podados drasticamente, apresentaram ramos de produção, secundários e terciários, fartamente distribuidos na copa. Cabe ressaltar, no entanto, que esse maior tamanho relativo de suas plantas, não constitui interesse ao sistema de pomar compacto. A aparente vantagem obtida no primeiro ano de frutificação, não deve se repetir nos anos seguintes, pois teria início, logo a seguir, a uma forte competição das plantas pelos fatores: luz, água e nutrientes. Um dos fatores mais negativos às plantas não podadas : ar... (de forma dnástica), diz respeito ao auto-sombreamento dado ao volume denso da copa. Ao tornarem-se excessivamente sombreados, os ramós de produção se enfraquecem, causando a improdutividade das plantas (BARBOSA et al., 1989a). Além disso, as plantas não podadas favorecem a reciclagem de doenças. Assim, os pessegueiros, ao serem conduzidos sob ultra-alta densidade de plantio, necessariamente devem ser podados drasticamente, com o intuito de formar copas novas, sadias e produtivas todos os anos. 


\subsubsection{Diferenciação floral}

4.1.2.1. Histologia, crescimento e desenvolvimento meristemático dos pessegueiros controles

Verificou-se através dos cortes histológicos, que a diferenciação floral dos pessegueiros 'Tropical' e 'Aurora-2' ocorreu praticamente na mesma época. As plantas, conduzidas sem a interferência da poda drástica, iniciaram a organogênese floral durante janeiro. Desse modo, cerca. de $90 \%$ dos meristemas vegetativos das gemas de flancos, evoluiram à condição reprodutiva. O domo meristemático alterou rapidamente sua forma (cônica), originando as partes florais. Na FIGURA 6 são apresentados os sete estágios da morfogênese floral do pessegueiro 'Tropical', conforme classificação de MONET \& BASTARD ( 1968 ).

Através da técnica da cultura in vitro, verificou-se que apenas os meristemas coletados e cultivados em fins de novembro desenvolveram-se vegetativamente. Os meristemas, nessa época, ainda não haviam sido induzidos à floração; assim, proporcionaram. vitroplantas normais de pessegueiro.

Os meristemas coletados e cultivados in vitro, em fins de dezembro, janeiro e fevereiro, transformaram-se em botões florais; após 30 dias de cultivo in vitro, muitos desses botões:oxidaram-se: Apesar dos meristemas te- 


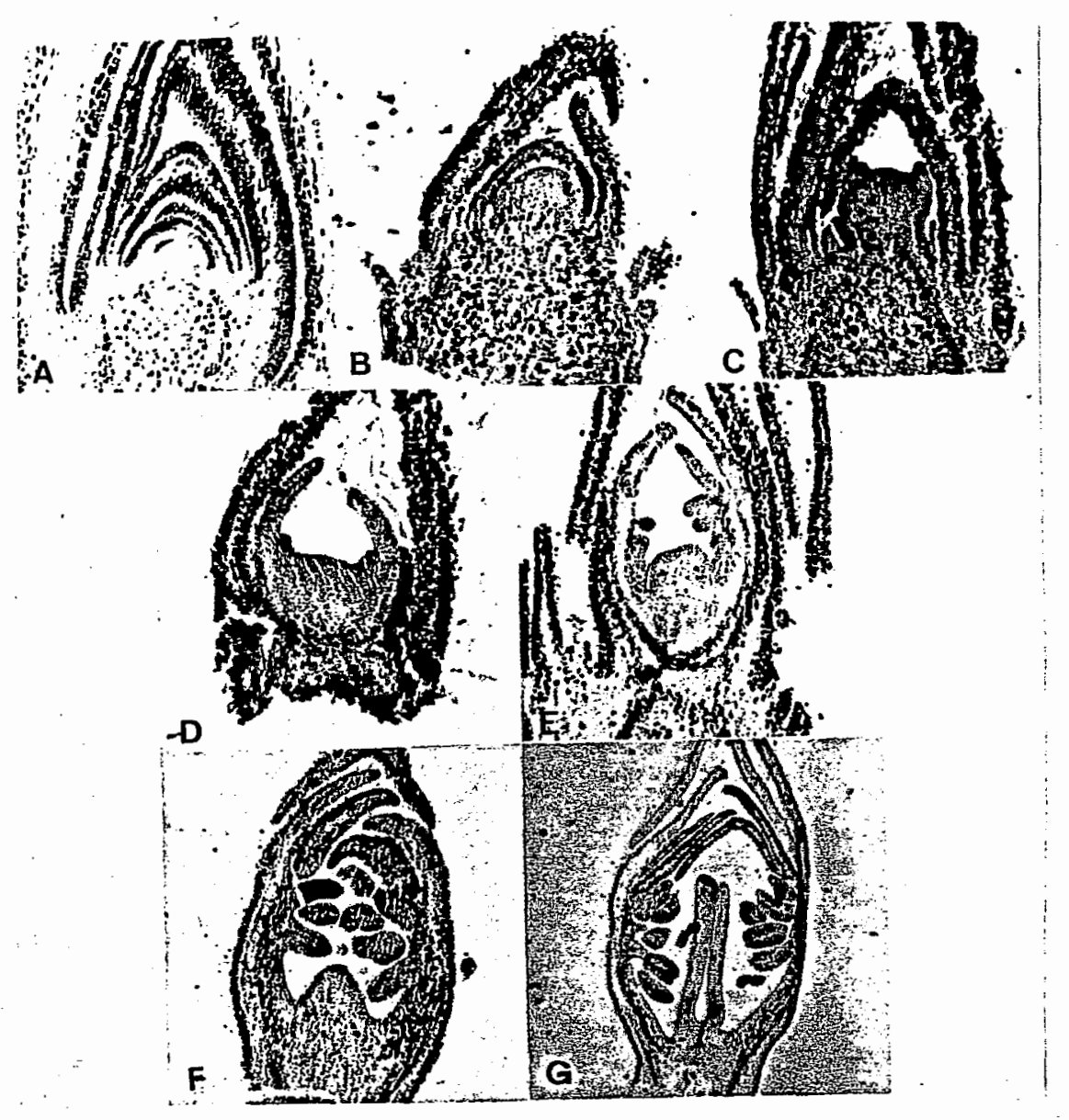

FIGURA 6. Estádios da morfogênese floral do pessegueiro

'Tropical' (aumento: 250x) 
rem se desenvolvido em meio de cultura suprido com $\circ$ 6-benzilaminopurina e expostos a condições de fotoperíodos longos, nenhuma vitroplanta de pessegueiro foi detectada. Esses dados confirmam a irreversibilidade dos meristemas florais. Os orgãos florais in vitro não se desenvolveram adequadamente após a antese.

Os dados histológicos e biotecnológicos evidenciaram que a indução floral, ou seja, o sinal recebido pela gema vegetativa para diferenciar-se em flor, deve ter ocorrido em fins de dezembro. A "desrepressão" gênica à diferenciação floral (BUBAN \& FAUST, 1982), provavelmente ocorreu no pico de crescimento das plantas, ou logo em seguida, durante o período de diminuição do funcionamento plastocrônico. Esses autores (op.cit.), bem como JACKSON " \& SWEET (1972) sugerem que com a redução do crescimento das plantas, - balanço hormonal modifica-se e os níveis de aúxina são elevados. Essas mudanças no metabolismo da planta são coincidentes com a redução do fotoperíodo.

Apesar de serem complexos e intricados os processẹs fisiológicos, os fatos indicam que a pequena diminuição do fotoperíodo pode refletir nos hábitos vegetativos e reprodutivos do pessegueiro. GOUVEIA (1984) pesquisando o cafeeiro (Coffea arábica L.), espécie brevediurna, formulou quatro hipöteses à ocorrência do fenômeno da indução floral. Dentre as hipóteses, destaca-se aquela em que a gema é indu- 
zida à floração, através de um mecanismo fotoperiódico refinado e extremamente sensivel. As plantas, então, detectariam a progressiva diminuição do comprimento do dia, a partir de 22 de dezembro.

No discernimento desta questão, torna-se imprescindível uma análise histoquímica de gemas e folhas do pessegueiro, coletando-se o material para análise, antes, durante e após o ciclo máximo de crescimento vegetativo. 'A A comparação dos dados dessa análise (fatores endógenos), com o fotoperíodo, temperatura e estado hídrico (fatores exógenos), provavelmente elucidará o fenômeno da indução floral desta espécie e de outras do mesmo gênero (Prunus).

Em fins de janeiro, histologicamente, a maioria das gemas de 'Tropical' e 'Aurora-2' encontravam-se entre os estádios "c" e "e", de acordo com a descrição de MoNET \& BASTARD (1968). Na terceira década de fevereiro, todas as gemas de flanco, estavam diferenciadas em flor. A formação completa do botão floral (estádio "g") ocorreu, no entanto, em março. Segundo esses autores (op.cit.), a flor do pesssegueiro é definitivamente estruturada, somente a poucos dias da antese; nessa ocasição ocorre a meiose, originando os gametas masculino's e femininos.

Analisando os cortes histológicos dos dois cultivares, verificou-se que 4 a $5 \%$ das gemas de centro (FIGURA 2), diferenciaram-se em botão floral. Em pessegueiro, 
as gemas de centro, normalmente não se transformam em flor; esse Índice de diferenciação floral de gemas centrais, obtido em 'Tropical' e 'Aurora-2', deve contribuir a uma maior densidade florífera.

Os botões florais, deste tratamento, permaneceram no estädio "g" durante os meses de março, abrile maio. Em junho, imediatamente após a quebra-da-endodormência das gemas, iniciou-se o desenvolvimento floral. Essa faseé distinguida como o "terceiro período" de crescimentó da gema, quando se processa a meiose (MONET, 1983).

A presente pesquisa evidenciou que em pessegueiro a indução e a diferenciação floral são precoces (dezembro-janeiro), porém, o desenvolvimento normal da flor é bem tardio' (junho-julho).

4.1.2.2. Histologia meristemätica dos pessegueiros sob poda drästica

A diferenciação floral de. 'Tropical' e 'Aurora-2'. foi retardada, em relação aos seus Controles, em: um, dois e três: meses, com as podas drásticas de 30.09, 30.10 e 30.11.86, respectivamente. (FIGURA.7). Os dois cultivares apresentaram, em seus respectivos tratamentos, o mesmo ritmo de organogênese floral.

Os pessegueiros, provenientes do tratamento $\underline{2}$, iniciaram a diferenciação floral de suas gemas em fevereiro. 


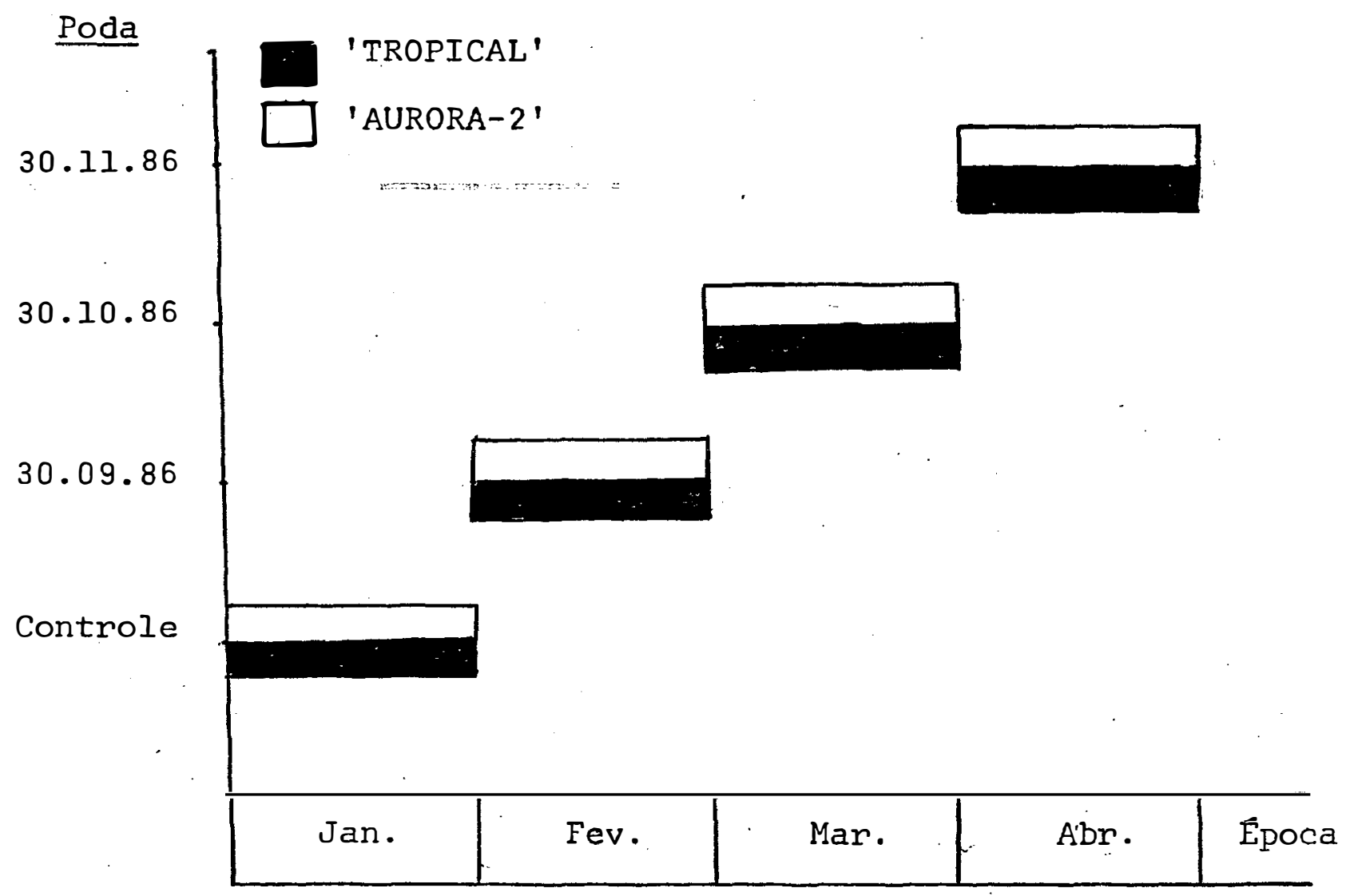

FIGURA 7. Época de iniciação floral dos pessegueiros 'Tropical' e 'Aurora-2', com base no Controle e podas drásticas de 3C. de setembro, 30 de outubro e 30 de novembro de 1986 . 
Em. fins de março, cerca de $80 \%$ dos botões florais, apresentavam completamente diferenciadas as sépalas (estädio c),pétalas (d), estames (e) e pistilo (g). Na terceira década de abril, todas as gemas de flanco atingiram o estädio "g" (botão floral completo). Nesse tratamento, o 'Tropical' diferenciou flores, em cerca de $2 \%$ das gemas de centro; no 'Aurora-2', todas as gemas de centro permaneceram vegetativas.

Os pessegueiros provenientes do tratamento $\underline{3}$ iniciaram a diferenciação floral em março (FIGURA 7). Em fins de abril, aproximadamente $40 \%$ dos botões florais de flancos, encontravam-se no estädio "g". Nessa época, os demais botões florais apresentavam-se em estādios "c", "d" e "e". Ao final de maio, a maioria destes botões encontravam-se em estádios "e". e "f". Neste tratamento, as gemas de centro dos dois cultivares não se diferenciaram em flores.

Os pessegueiros provenientes do tratamento $\underline{4}$ somente iniciaram a diferenciação floral a partir de abril (FIGURA 7). Em fins de maio, cerca de $20 \%$ dos botões florais estavam formadós; os demais botões encontravam-se em estádios florais bem atrasados. Pela FIGURA 8 pode-se verificar, para as êpocas de poda drästica, a relação existente entre o tamanho dás gemas e.à organogênese floral de 'Tropical'. As fotomacro e micrografias constituídas são referentes a março de 1987 . 


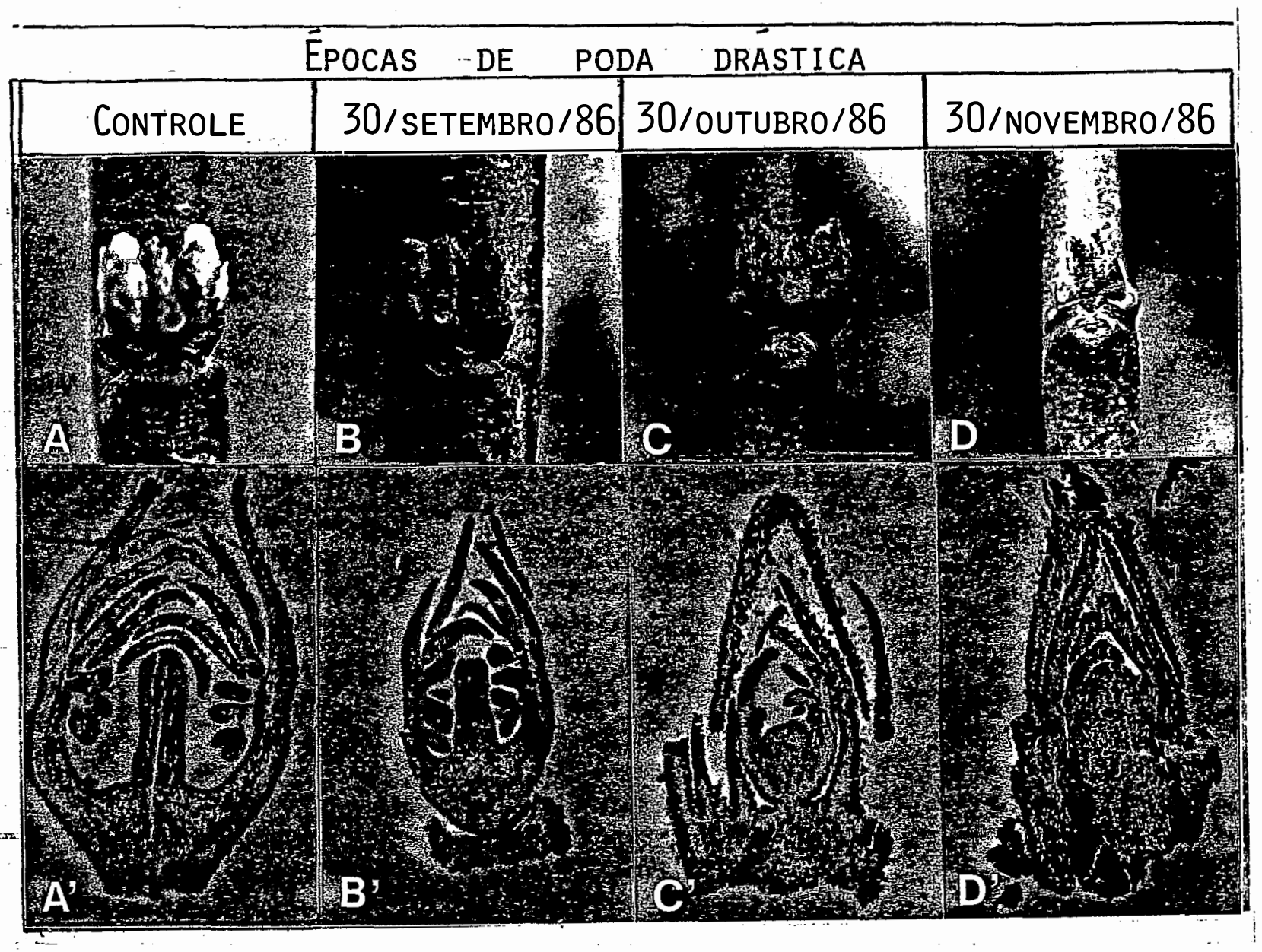

FIGURA 8. Relação entre o tamanho das gemas e os estádios de diferenciação floral no pessegueiro 'Tropical', com base - no Controle e épocas de poda drástica. $A^{\prime}$ e $B^{\prime}=$ estádio "g"'; . C' = estádio "e"; D' $^{\prime}$ estādio "a". Documentação fotomacro-micrográfica baseada em 26 de março de 1987. AAumentos: A, B, C e D $=2 \mathrm{x} ; \quad \mathrm{A}^{\top}=100 \mathrm{x}$; $B^{\prime}, C^{\prime}$ e $D^{\prime}=75 x$. 
Observa-se pelas diversas épocas de iniciação floral, que o(s) fator(es) indutivo(s) à transformação da gema, continua(m) presente(s) até mesmo após o verão. Em abrill, a duração do fotoperíodo aproximou-se a 11:30 horas, portanto, cerca de menos duas horas de brilho solar por dia em relação a final de dezembro. A temperatura média e a precipitação pluviométrica, em abril de 1987 , foram de $22,4^{\circ} \mathrm{C}$ e $154,8 \mathrm{~mm}$, respectivamente; esses indices, mesmo inferiores aos de dezembro/86 e janeiro/87 (APÊNDICES 1 e 2), não interferiram repressivamente no processo fisiológico indutor de floração.

De acordo com os resultados obtidos, pode-se supor que o limiar críticco dos pessegueirosà indução floral, acha-se próximo a 13:30h de luz, sendo fotoindutivos os períodos luminosos abaixos deste limite. Este ciclo fotoindutivo, provavelmente se estenda até maio-junho; após esta época a fotoperíodo volta a aumentar.

Os dois cultivares foram igualmente induzidos à organogênese floral, cerca de cinco meses após a poda, quanḍ atingiram certo grau de maturidade fisiológica. E provável que podas muito tardias, impeçam os pessegueiros de produzirem flores no mesmo ciclo vegetativo. Para responder esta questão, hã necessidade, no entanto da execução de podas drásticas a partir de dezembro. 
4.1.3. Quantidade de nós e de gemas nos ramos

0 número de nós de gemas por metro de ramo (m.r.) de 'Tropical' e 'Aurora-2' foi influenciado significativamente $(P<0,01)$, pelas épocas de poda drástica (TABELA 4).

A constatada diminuição do indice de nós, por metro de ramo dos pessegueiros podados, deve-se ao maior comprimento dos internós. Esse distanciamento dos internós é típico em ramos de plantas jovens, com crescimento acelerado e vigoroso (ZIMMERMAN, 1972; WESTEWOOD, 1978). A qualidade de luz que incide sobre a planta em desenvolvimento, pode também influenciar no comprimento dos internós (FELIPPE, 1979).

Os pessegueiros adultos, por se desenvolverem com menor vigor, geralmente produzem quantidades maiores de nós por centímetro de ramo (c.r.). 0 nümero de nós/m.r. produzido por 'Tropical e 'Aurora-2' (tratamento I), superou ao do pêssego norte-americano 'Redhaven', que em cultivo normal apresentou 42 nós/m.r. (MARINI; 1986). Esse número de nós/ m.r.: de 'Redhaven' equivale ao das plantas de 'Tropical' podadas em 30 de setembro.

0 número de nós por centímetro de ramo (c.r.) calculado para 'Tropical' $(0,49)$ e 'Aurora-2' $(0,52)$, assemelha-se ao de 'Harken' e 'Earliglo' (mutação de 'Radhaven'), que produziram em ramos de $60 \mathrm{~cm}, \bar{x}=0,47$ e 0,50 nós/ic.r., 


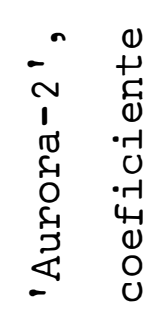

0

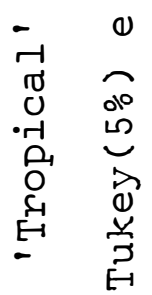

क मे मू

गु ठ

\begin{tabular}{ll}
0 & 0 \\
0 & 0 \\
0 & 0 \\
0 & $c_{1}$ \\
0 & 0 \\
0 & \multicolumn{1}{c}{} \\
0 & 0
\end{tabular}

$\infty>$

$\begin{array}{cc}0 & 0 \\ 0 & 0 \\ 0 & 0 \\ 0 & + \\ 0 & 0 \\ 0 & 0 \\ 0 & 0 \\ 0 & 0\end{array}$

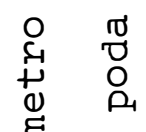

$\begin{array}{ll}\text { c1 } & 0 \\ 0 & 0 \\ 0 & \infty\end{array}$

\begin{tabular}{lll}
$\infty$ & 0 & $\dot{0}$ \\
0 & + & $\therefore$ \\
$\mathbb{1}$ & 0 & $\infty$ \\
0 & 0 & 0 \\
0 & $\stackrel{0}{1}$ & \multicolumn{1}{c}{} \\
0 & 0 & 0 \\
0 & 0 & 0
\end{tabular}

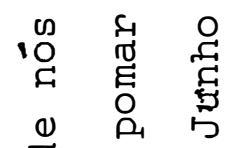

ह

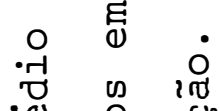

粦 0

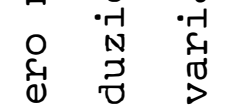

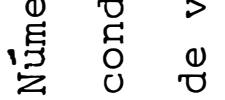

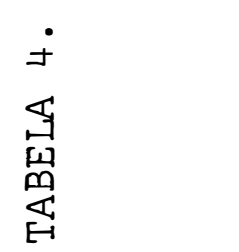

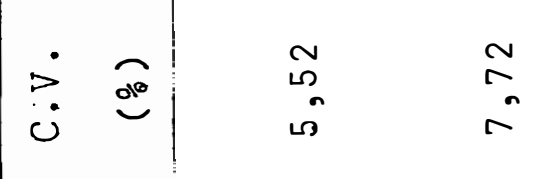

97. 
respectivamente (SOLEILLE, 1981)(12). Pela FIGURA 9 pode-se comparar o efeito das épocas de poda drástica no número de nós/c.r.

Os pessegueiros 'Tropical' e 'Aurora-2' provenientes dos tratamentos $\underline{3}$ e $\underline{4}$, além de apresentarem internós longos, foram prejudicados na homogeṇeidade de formação das gemas. Ambos cultivares apresentaram elevada quantidade de nós com ausência total de gemas. Nestes tratamentos, o número de gemas por nó de ramo (n.r.) foi afetado significativamente $(\mathrm{P}<0,01), 0$ 'Tropical' e 'Aurora-2' (tratamento I), apresentaram $\bar{x}=2,70$ e 2,86 gemas/n.r., respectivamente; esses indices foram bastante reduzidos com as épocas mais tardias de poda drástica (FIGURA 10), notadamente no 'Aurora-2'.

o 'Aurora-2' que mostrou maior suceptibilidade à poda drástica de 30 de novembro, reduziu 0 número de gemas tanto por c.r. quanto por $n . r$. A sua deficiência na formação de gemas, pode ser resultante das condições climáticas desfavoräveis na época específica de crescimento. Suas plantas podadas tardiamente, somente desenvolveram as gemas a paṛtir de março-abril. Nessa época, o comportamento vege-

(12) SOLEILLE, B. Biologie florale du pêcher: relation entre la qualite des fleurs et la chute des fruits. Université Paris Sud - Orsay, França, 1981, 32p. Relatório de estágio. (não publicado). 
99.

Poda

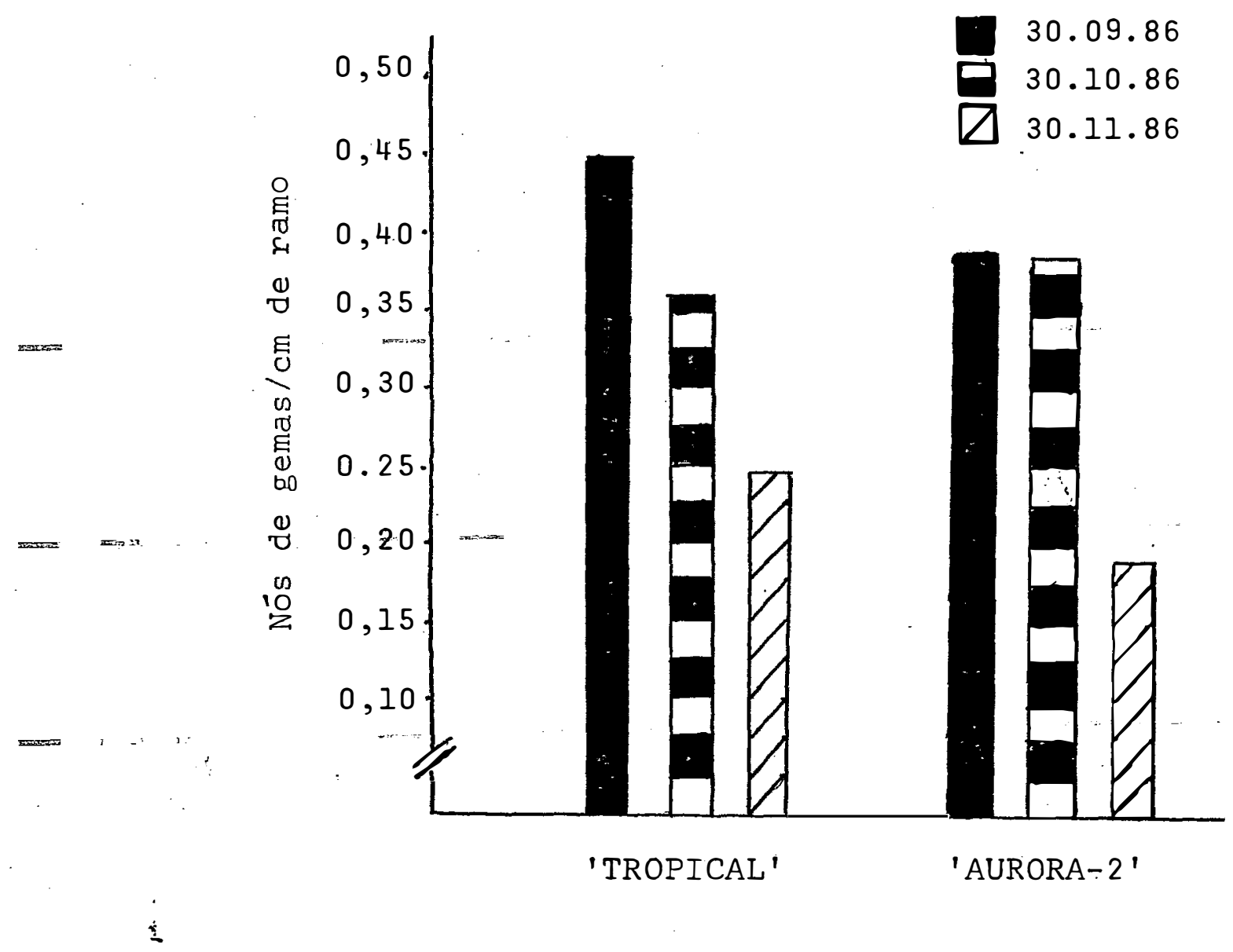

FIGURA 9. Histograma do número médio de nós/centímetro de ramo dos pessegueiros 'Tropical' e 'Aurora-2', em pomar compacto, sob poda drástica. 
Poda

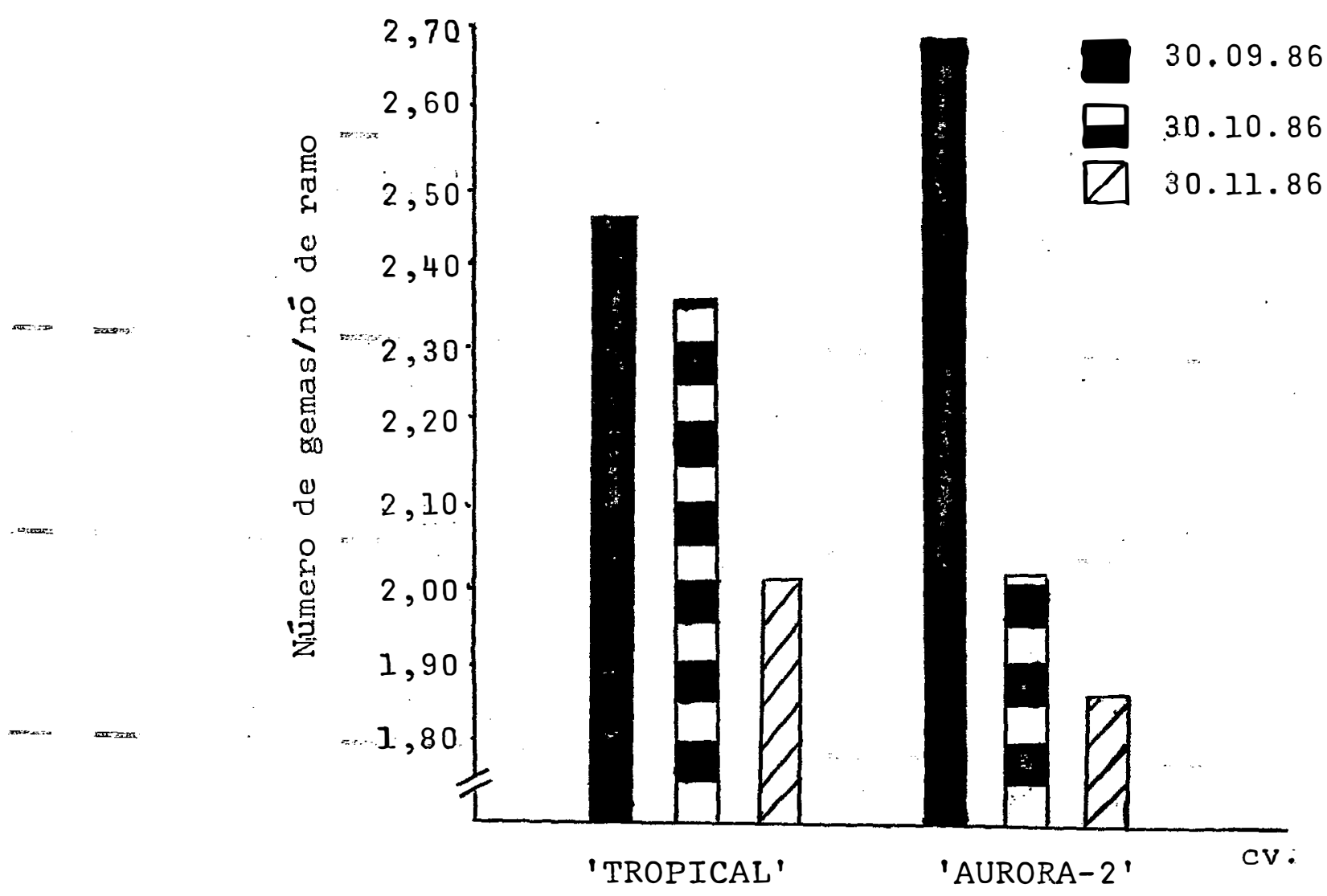

FIGURA 1Q. Histograma do número médio de gemas/nó de ramo dos pessegueiros 'Tropical' e 'Aurora-2', em pomar compacto, sob poda drásticà. 
tativo da planta provavelmente se altera (<fotoperíodo, < temperatura, < precipitação), com a intensificação da síntese de hormônios inibidores de crescimento. Com isso, a organogênese é afetada devido a diminuição natural do rítmo das divisões celulares.

o 'Tropical', considerado do tipo geneticamente precoce, antecipou o desenvolvimento das gemas (APÊNDICE 3, 4, 5 e 6). No entanto, nas podas tardias, a organogênese de suas gemas foi inferior às plantas dos tratamentos I e. 2. Os pessegueiros destes tratamentos desenvolveram as gemas em dezembro-janeiro, época essa de máximo metabolismo celular.

4.1.4. Desenvolvimento: de gemas vegetativas e floriferas

As podas drästicas causaram nos pessegueiros um efeito supressivo no desenvolvimento de gemas vegetativas e floríferas. Verificou-se com as podas uma sensível redução destes tipos de gemas por porção de ramo (FIGURA II).

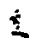

o 'Tropical' e o 'Aurora-2' (tratamento.' I), produziram $\bar{x}=1,03$ e 0,29; 1,06 e 0,43 gemas floriferas e vegetativas/c.r., respectivamente. Com as podas drásticas, houve uma forte supressão de gemas floriferas de 19 a $74 \%$ e de gemas vegetativas de 10 a $62 \%$; os maiores indices de su- 


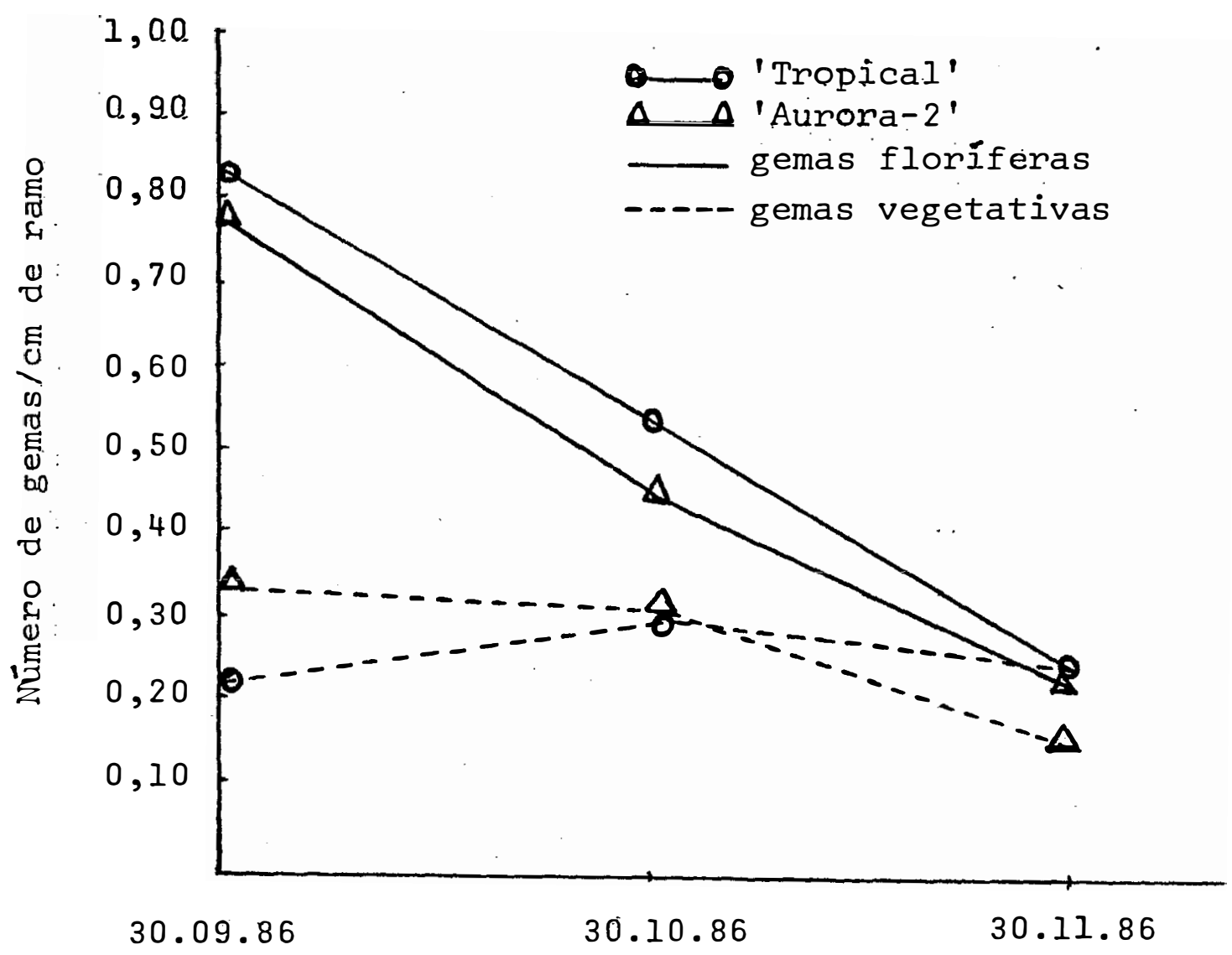

FIGURA 11. Nümero médio de gèmas floríferas e vegetativas por centímetro de ramo dos pessegueiros 'Tropical' e 'Aurora-2, em pomar compacto, sob

poda drástica. 
pressão foram proporcionados pela poda de 30 de novembro.

Os tratamentos $\underline{3}$ e $\underline{4}$ causaram em 'Tropical' tendências para o aumento do número de gemas vegetativas/c.r.; as gemas floríferas, entretanto, foram sensivelmente diminuídas. Em 'Aurora-2' houve redução drästica. em ambos tipos de gemas/c.r.

O 'Aurora-2', proveniente do tratamento $\underline{4}$, devido ao baixo desenvolvimento de gemas vegetativas/c.r., apresentou uma copa com certa deficiência de folhas e ramos: Nessas plantas a luminosidade incidente atravessava a camada foliar, atingindo com maior intensidade o solo abaixo da co$\mathrm{pa}$.

As diferentes épocas de poda drástica também interferiram no desenvolvimento e na qualidade das gemas vegetativas e floriferas dos pessegueiros (FIGURA 12). Nos dois cultivares, houve aumento de gemas de vegetação; :as gemas florais, no entanto, diminuíram acentuadamente. Nas plantas do tratamento $\underline{4}$ a porcentagem de gemas floriferas e vegetativas desenvolvidas foi bastante similar.

- 0'Tropical' e o 'Aurora-2' (tratamento I), por sua vez, atingiram $\bar{x}=78,1$ e 21,$9 ; 71,3$ e $28,7 \%$ de gemas floriferas e vegetativas/n.r., respectivamente. 0 nümero de gemas floríferas/n.r. apresentado por 'Tropical.' $(2,11)$ e 'Aurora-2' $(2,04)$, foi inclusive maior que diversos cultivares norte-americanos. Pessegueiros e nectarineiras cond'Har- 


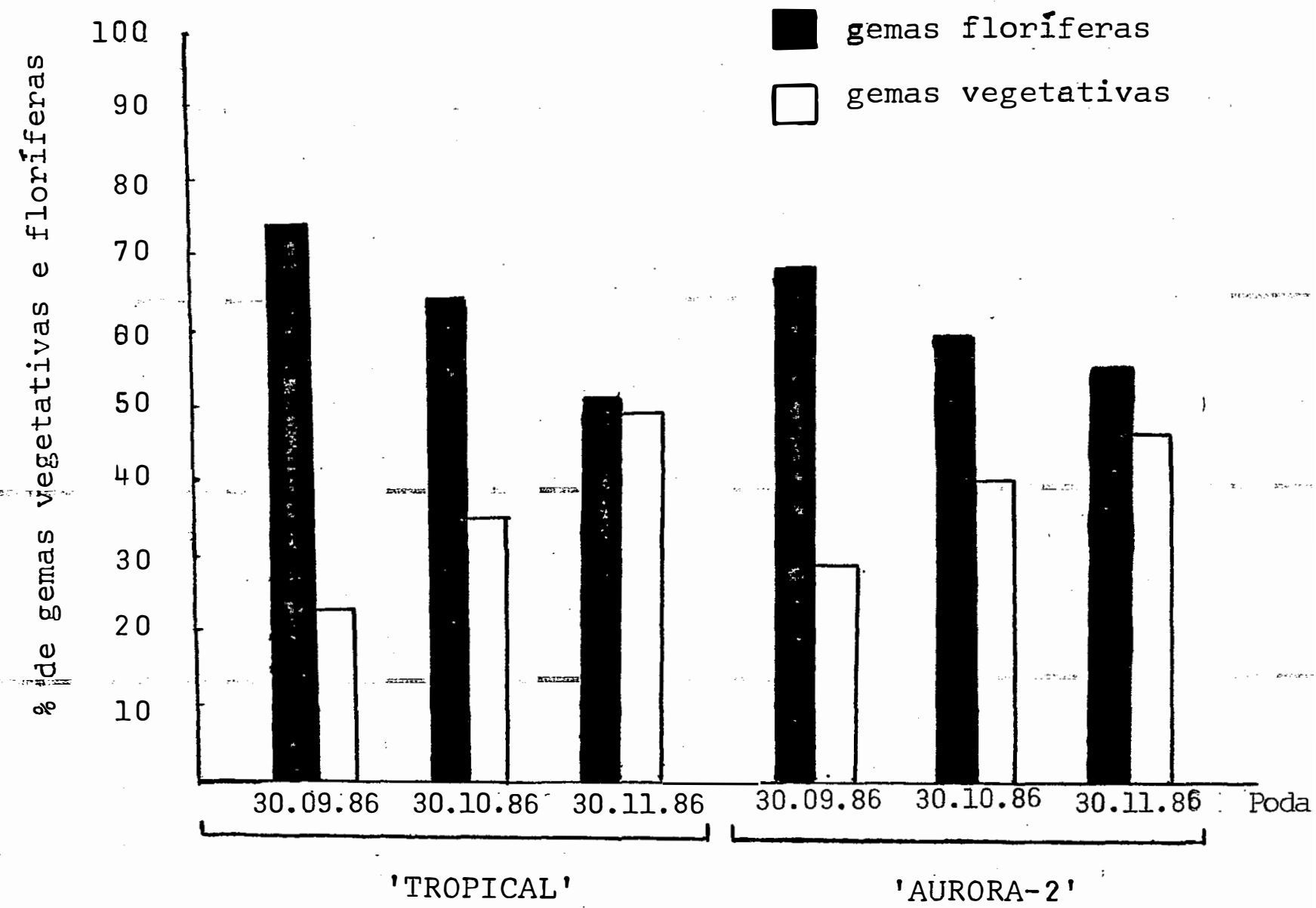

FIGURA 2. Histograma da porcentagem de gemas floríferas è vegetativas dos pessegueiros 'Tropical' e 'Aurora-2', em :pomar compacto, sob poda drástica. 
ko', 'Nectared-4', 'Nectared-7', 'Redhaven' e 'Sunprice, proAuzem $\bar{x}=1,59 ; 1,26 ; 1,20 ; 1,07 ; 1,03$ flores/n.r., respectivamente (WERNER et al., 1988). Nesses materiais foi constatado uma relação: ano x cultivar, altamente significativa, quanto a diferenciação..de gemas florais. Numa lista apresentado por esse autor (op. cit.), cerca de 50\% dos cultivares apresentaram-se com menos de uma gema florífera/nó.

Em nosso caso, os cultivares pesquisados, mesmo podados drasticamente, produziram grande nümero de gemas floriferas/n.r. Foram constatados para 'Tropical'e 'Aurora-2', nas plantas provenientes dos tnatamentos $2 \underline{2} \underline{3}$ e $\underline{4,} \bar{x}=1,88$ e 1,86; 1,53 e 1;26; 1,04 e 0,99 gemas floríferas/n.r., respectivamente.

BYRNE (1986) relata que a presença de alto nümero.de gemas floriféras/nó, constitui o principal fator à uma elevada frutificação éfetiva. Nessa linha de raciocínio, pode-se dizer que a poda drästica de fins de setembro constitui-se na mais adequada, pois não compromete a quantidade de gemas florais/n.r. Outras êpocas mais tardias de poda dráştica não constitui grande vantagem ao pessegueiro; hả redução em até $50 \%$ no potencial de gemas floríferas, mesmo utilizando-se de cultivar bem precoce como o 'Tropical'.

4.1.5. Floração e palinologia

o tratamento químico de quebra-de-endodormên- 
cia, realizado em 29 de maio de 1987, propiciou aos pessegueiros 'Tropical' e. 'Aurora-2' uma floração normal, em fins de junho e início de julho, cerca de 25 a 40 dias do referido tratamento (APENDICES 3, 4, 5 e 6). A temperatura média hibernal, não muito fria, de junho $\left(16,5^{\circ} \mathrm{C}\right)$ e de julho $\left(19, I^{\circ} \mathrm{C}\right)$, favoreceu o rápido desenvolvimento floral dos pessegueiros.

As plantas provenientes dos tratamentos $\underline{1}$ e $\underline{2}$ apresentaram as melhores florações, cujo pico ociorreu de 25 a 35 dias após a aplicação do produto de quebra-de-endodormência. As plantas das demais épocas de poda drástica atrasaram o início de floração.

As flores de 'Tropical' (tratamento I' e 2) apresentaram-se volumosas, com pétalas de coloração rósea; anteras médias, bem amarelas com bordas avermelhadas; pistilos de 11 a $14 \mathrm{~mm}$ de comprimento e estígma grande. 0 'Aurora-2' (tratamento $\underline{I}$ e $\underline{2}$ ) apresentou flores pouco menores,com pétalas róseas-fortes; anteras médias, amarelo-avermelhadas pistilo de 10 a $12 \mathrm{~mm}$ de comprimento, com estịgma médio a grantile.

A reação fisiológica dos pessegueiros dos tratamentos $\underline{3}$ e $\underline{4}$, após a indução de quebra-de-endodormência, reafirmou a imaturidade das plantas à uma adequada filoração. Além do atraso e da heterogeneidade no desenvolvimento floral, as plantas apresentaram ainda baixo indice de flores por 
ramo. Essas flores, menos exuberantes (pequenas e com pétalas róseas bem claras), tenderam a se tornar deiscentes precocemente: 0 curto período de floração verificado, provavelmente, decorre do baixo grau de fertilização das flores, causado pela imaturidade fisiológica da planta. As flores não fertilizadas, geralmente permanecem menos tempo abertas e são mais räpida e facilmente abortadas.

As pesquisas conduzidas em laboratório, também evidenciaram a maior sensibilidade dos. pessegueiros às podas drásticas. Ao se atrasar a poda, ocorreu redução sutil no número de anteras por flor e acentuada na quantidade de grãos de pólen por antera. Pelas tABELAS 5 e 6 , pode-se verificar o número de anteras/flor e grãos de pólen / antera de 'Tropical' e 'Aurora-2', e os respectivos intervalos de confiança para a média. Normalmente, os pessegueiros mais produtivos, apresentam cerca de 35 a 50 anteras/flor e de 40 a 80 mil grãos de pólen/flor (BARBOSA et al., 1989c). 0 'Tropical' e o. 'Aurorà-2'; (tratamento ll ) produziram $\bar{x}=85.049$ e 50.875 grãos de pólen/flor, respectivamente.

A análise de variância da germinação dos grãos de pólen revelou efeito significativo $(P<0,01)$, em relação às épocas de poda drásțica (TABELA 7). Comparando-se as médias da germinação in vitro do pólen, pelo teste de Tukey 5\%, verificou-se no tratamento 4 uma significância estatística aos dois cultivares. Os grãos de pólen dos pessegueiros do tratamento $\underline{2}$ apresentaram leve tendência de germinação in vi- 


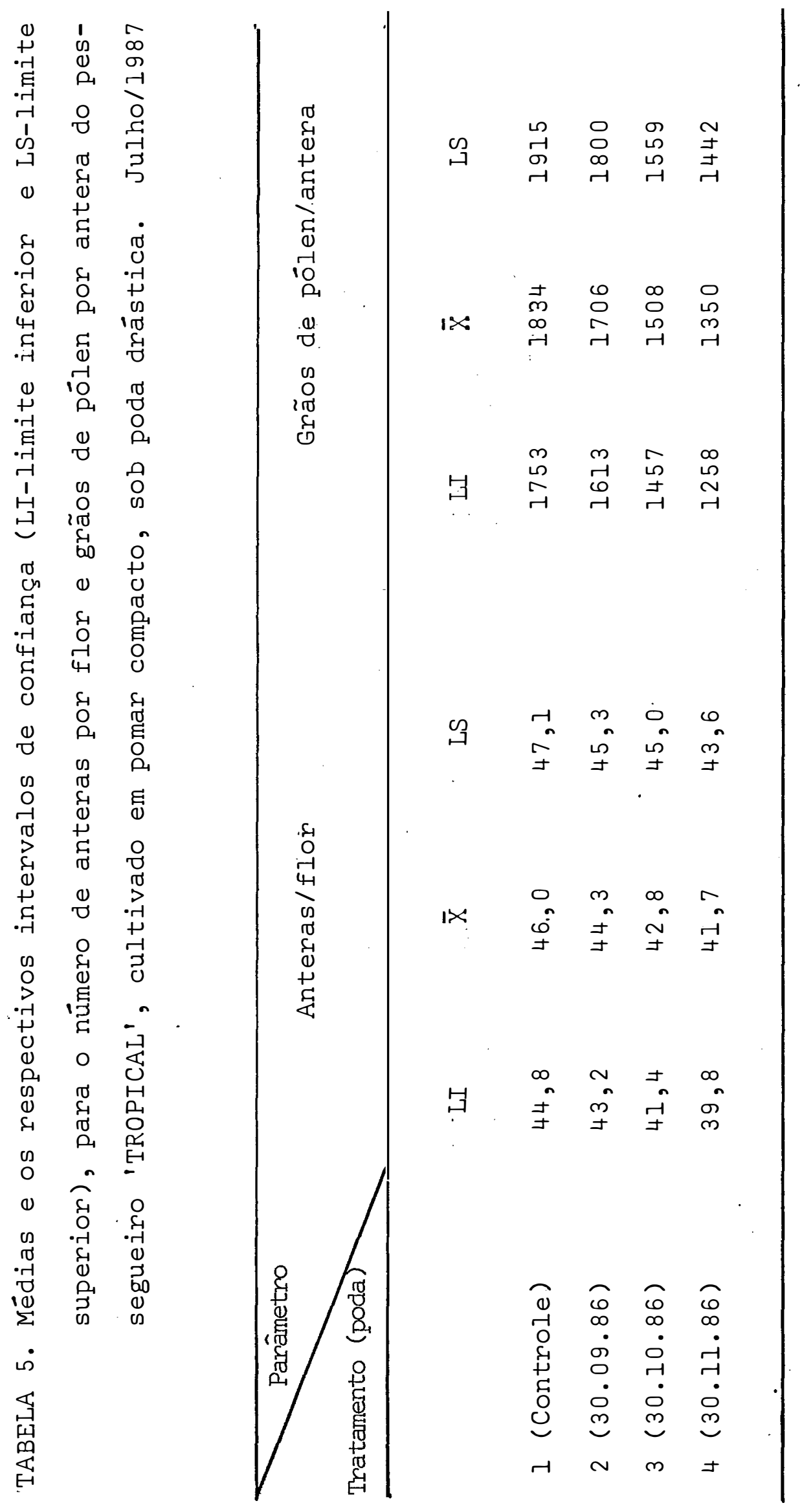

108. 

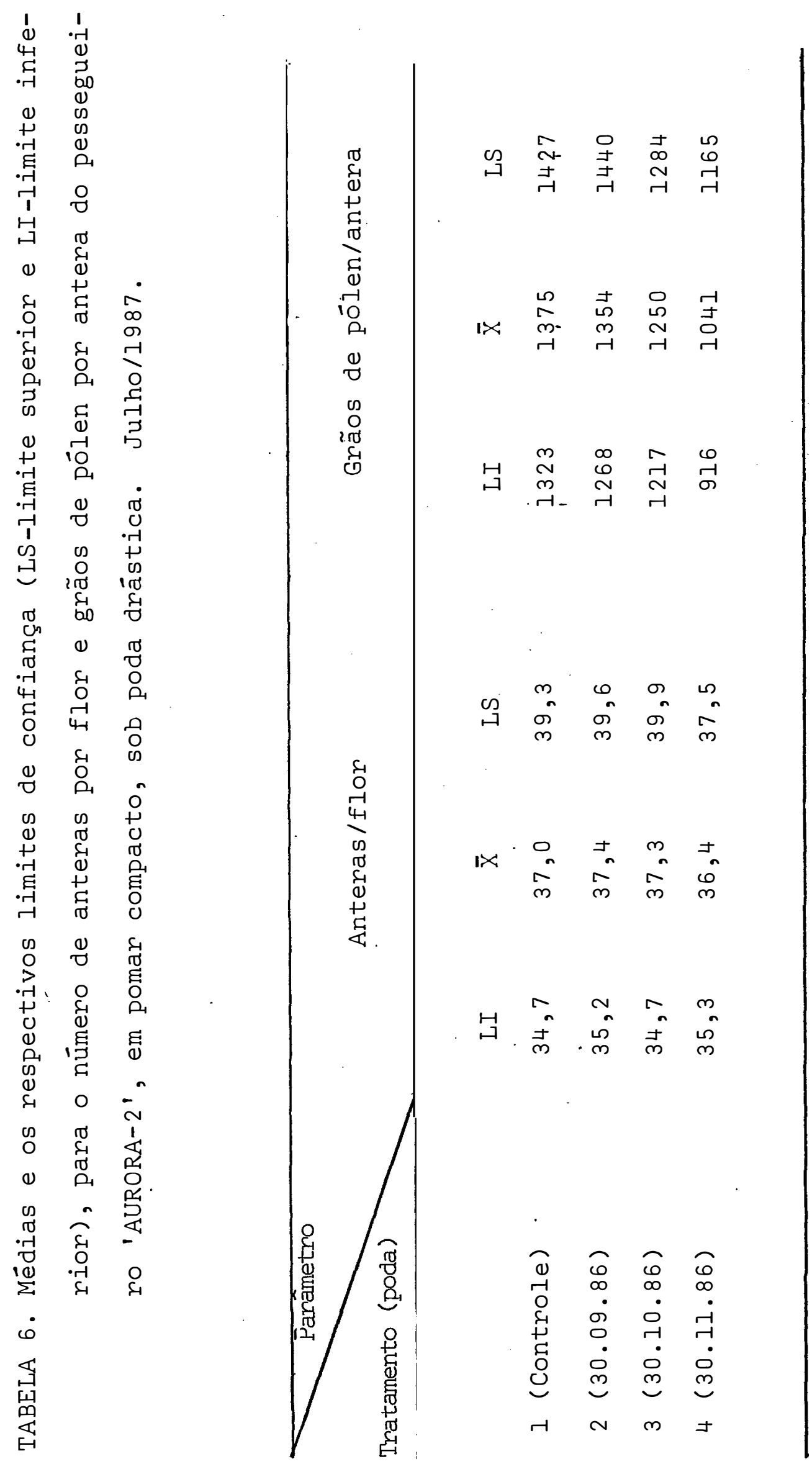

109. 


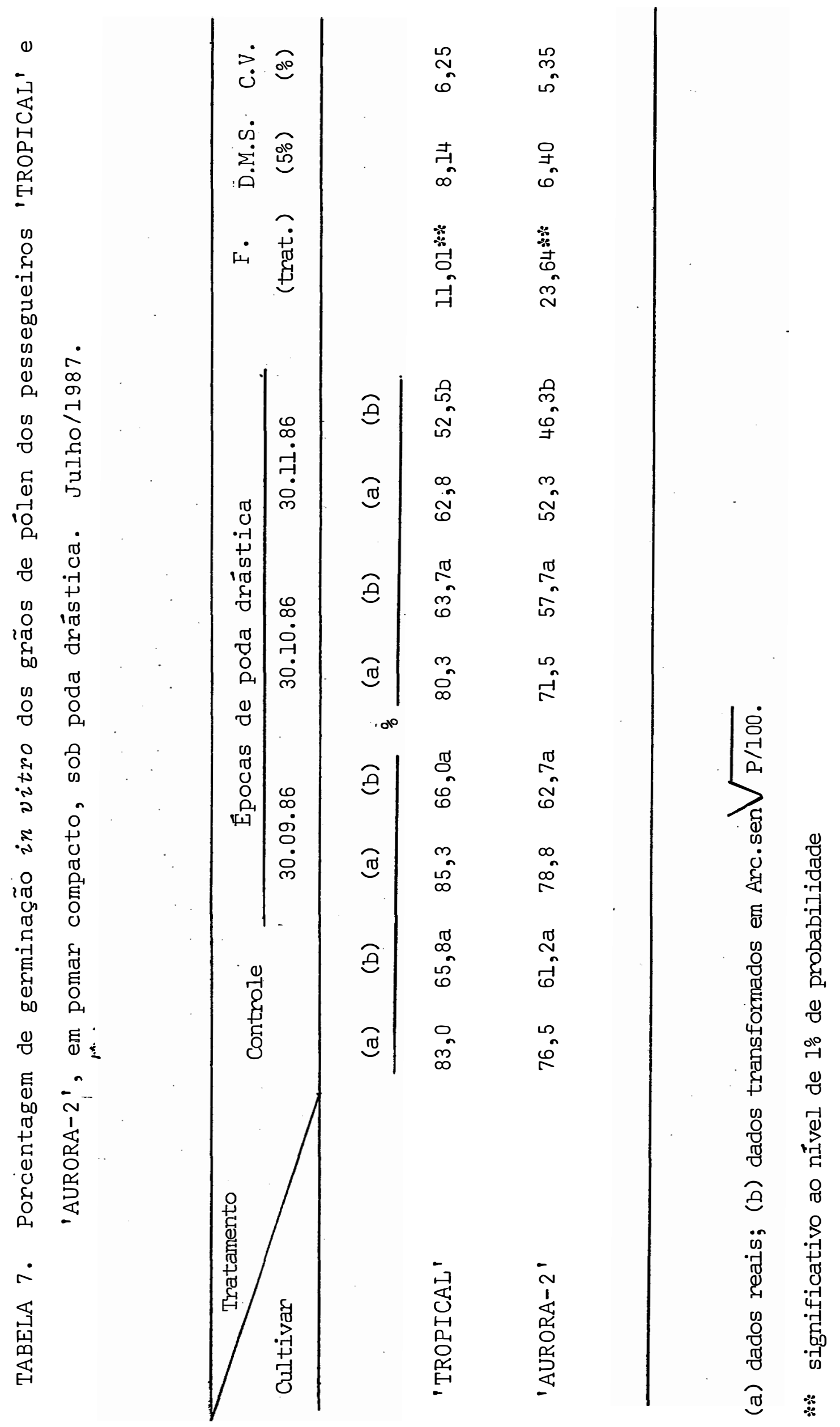


tro, que estatisticamente não foi significativa.

A diferença dos Índices polínicos verificada entre os pessegueiros, constitui-se em característica estritamente varietal. O número inferior de grãos de pólen/flor em 'Aurora-2' (FIGURA 13), decorre principalmente da menor quantidade de anteras. Os maiores índices de grãos de pólen são verificados em cultivares de elevado número de anteras/ fflor. A quantidade de pólen existente numa antera, por sua vez, parece não influenciar na germinação. No... laboratório, entretanto, os fatores que podem afetar: a: germinação são principalmente: o meio de cultura e a temperatura (MEDEIROS, 1979 ).

A significativa diminuição da viabilidade polínica dos pessegueiros, demonstra, de certo modo, a imaturidade do gameta masculino $\left(\sigma^{\nexists}\right)$. A floração que foi forçada pelo tratamento químico, pode, em certo grau, ter prejudicado a maturação completa dos grãos de pólen. Em pessegueiros adultos a maturação normal desse gameta ocorre somente a poucos.dias da àntese (JRAIDI, 1983; MONET, 1983). O gameta feminino ( $(q)$, que acompanha esse mesmo padrão de desenvölvimento, se afetado, também poderá prejudicar o processo de fertilização dos pessegueiros podados tardiamente. 


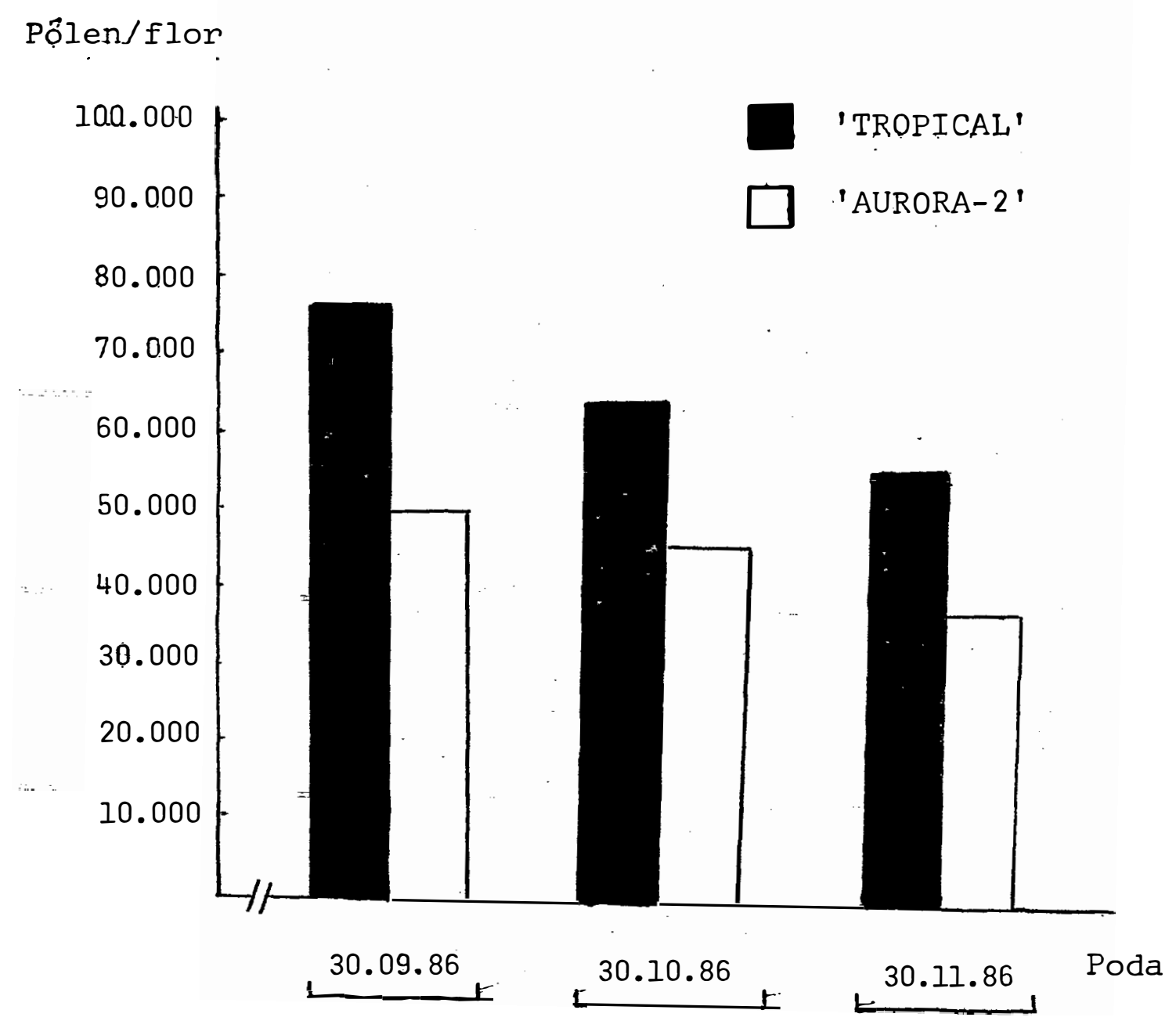

FígURA 13. Histograma do número médio de grãos de pólen por flor dos pessegueiros 'Tropical' e 'Aurora-2!, em pomar compacto, sob poda drástica. 


\subsubsection{Frutificação}

\subsubsection{Frutificação efetiva}

A porcentagem de frutificação efetiva de 'Tropical' e 'Aurora-2' foi afetada significativamente $(\mathrm{P}<0,01)$, de acordo com as épocas de poda drástica (TABELA 8 ).

$$
\text { Em 'Tropical', a frutificação efetivia dos }
$$

tratamentos $\underline{1}$ e $\underline{2}$, não diferiram entre si, pelo teste de Tukey $5 \%$. Nestes tratamentos foram verificadas elevadas porcentagens de pegamento de frutos. No tratamento 4 , ocorreu uma redução em mais de $50 \%$ da frutificação efetiva dos pessegueiros, com quedas normais de flores e de frutos jovens. Esses fatos reforçam a hipótese de que pessegueiros decepados com atraso são fisiologicamente imaturos a uma floração e frutificação normalmente precoces. A necessidade, de um lado, em se antecipar a quebra-de-endodormência causa, de outro, a baixa fertilidade dos órgãos reprodutivos dos pessegueiros imaturos.

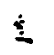

A frutificação de 'Tropical' e 'Aurora-2' (tratamento $\underline{1}$ ), assemelha-se a dos cultivares 'Capdeboscq', 'Coral' e 'Morro Redondo'; esses pessegueiros cultivados nas condições climáticas de Pelotas, RS, alcançaram uma frutificação efetiva entre 30 e 40\% (BASSOLS, 1980). Conforme relato de MARINI (1986) o pêssego 'Redhaven' também mostrou Indice de frutificação semelhante ( $34 \%$ ), com uma média de 


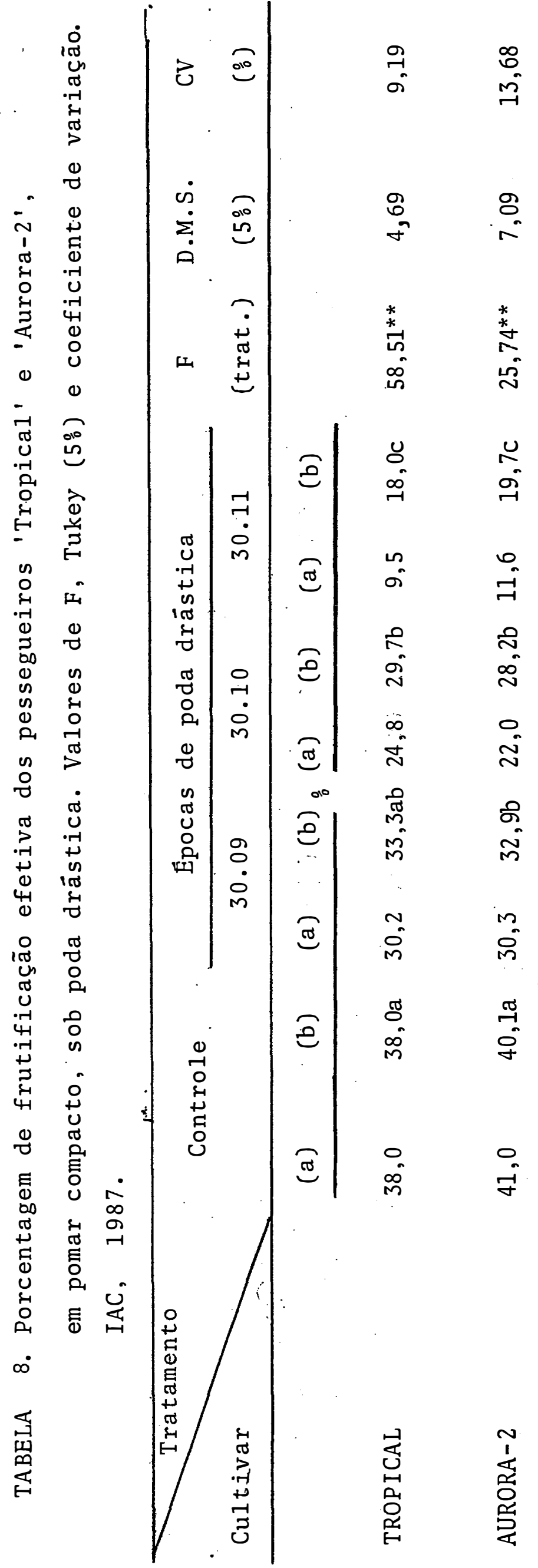

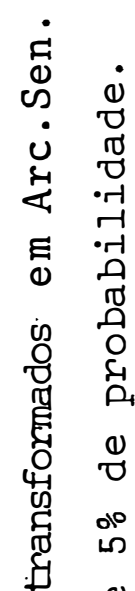

o 0

चु

อ 0

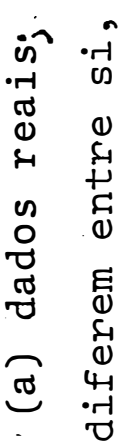

i)

芴

苗

م

مอ

吕

() ह

00

म 0

㫕

가 00

in o

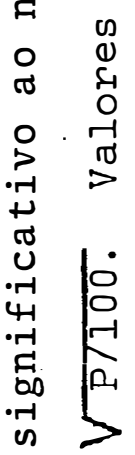


14 frutos/m.r.

O nümero de frutos/m.r. em 'Tropical' e 'Aurora-2' também foi significativamente diminuindo $(P<0,01)$, com as épocas de poda drástica (TABELA 9). No entanto, essa diminuição de frutos, à exceção do tratamento $\underline{4,}$ não deve constituir problemas à produção das plantas. Essa afirmativa baseia-se no fato, de que pessegueiros conduzidos sob ultra-alta densidade de plantio não admitem númeṛo excessivo de frutos/m.r.; acima de certa quantidade ocorre uma indesejāvel diminuição no peso médio e mesmo na qualidade organoléptica da fruta. Acredita-se que um número superior a cinco frutos/m.r. reduza excessivamente o seu peso médio final. Nos tratamentos $\underline{2}$ e $\underline{3}$, o número de frutos efetivos verificado/m.r. ultrapássou o mínimo necessário (TABELA 9).

Essa elevada quantidade de frutos/m.r. dos pessegueiros dificultou a operação manual de raleio. Apesar dessa dificuldade operacional, houve nos tratamentos $\underline{1}$ e $\underline{2}$, uma homogênea distribuição dos frutos nos ramos; isto permitiu que fossem deixados de dois a cinco frutos de igual padrã̃o nos ramos.

Nos pessegueiros dos tratamentos $\underline{3}$ e $\underline{4}$, nem sempre foi possível manter esse mesmo número de frutos/m.r. Em alguns casos, houve excessivo número de abortos de frutos em crescimento, o que contribuiu para sua ausência em muitos ramos. Em todas as plantas destes tratamentos foi comum a constatação de apenas um fruto por ramo. 

4.1.6.2. Crescimento dos frutos de 'Tropical'

o padrão de crescimento dos frutos do 'Tropical' seguiu uma curva sigmoidal dupla (FIGURA 14).

Estádio 1. 0 crescimento visível dos frutos do 'Tropical' iniciou-se poucos dias após'a antese. Cerca de 10 dias após a abertura total do botão floral, as pétalas e o pistilo se apresentavam quase secos; as sépalas, porém, continuavam verdes e bem aderentes ao pequeno fruto. Essas peças florais destacaram-se dos frutinhos $\bar{x}=19$ dias após a abertura da flor. Com 32 dias de idade, os frutinhos apresentavam-se com bastante pilosidade e com pequeno ápice, que ainda continham fragmentos secos do pistilo. Com 40 dias, os pequenos frutos já se apresentavam com coloração avermelhada em $30 \%$ da superfície; o caroço ainda continuava tenro. Com 48 dias, a pilosidade continuava bem evidente nos pequenos frutos. Nessa época o caroço já mostrava indícios de enrijecimento, porém o embrião áinda não se desenvolvia de forma bem visível.

Estádio II. Com 54 dịas de idade, os frutos demonstravam pouco crescimento; o caroço tornava-se mais firme, e o embrião permanecia ainda sem desenvolvimento bem visível. Aos 61 dias, os integumentos já se 1 apresentavam cheios de albümen e o saco embrionário media cerca de $3 \mathrm{~mm}$ de comprimento; o embrião era pouco visivel a "olho nu" 


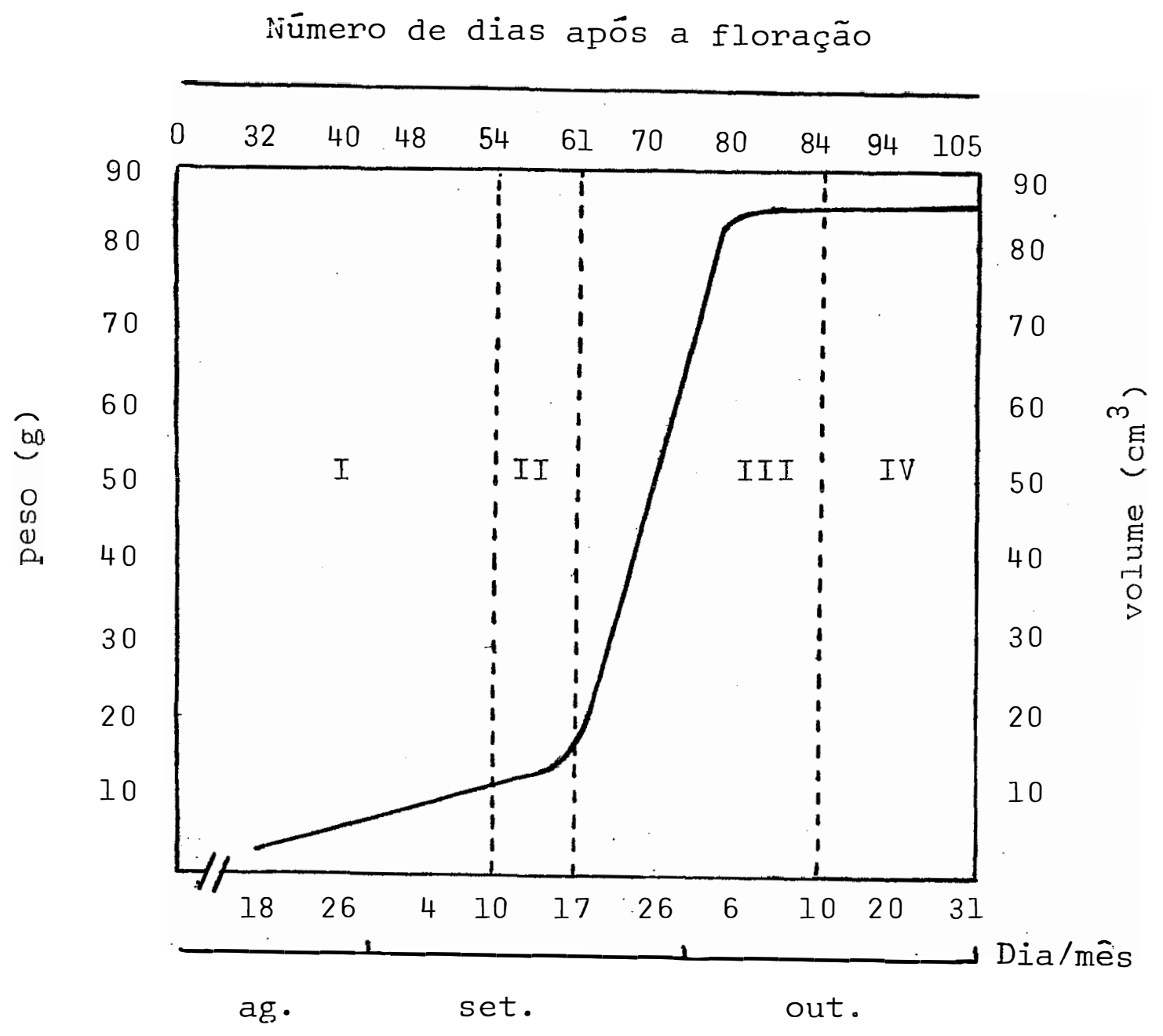

FIGURA 14. Crescimento dos frutos do pessegueiro 'Tropical', conduzido no sistema de pomar compacto. (Bordura). 
Estádio III. Após 61 dias da floração, verificou-se um intenso crescimento dos frutos, o que the conferiu aspecto mais globoso, com ápice pouco saliente. Com cerca de 70 dias, as características marcantes foram: intensificação da coloração vermelha da epiderme; caroço bem duro, embrião com $9,5 \mathrm{~mm}$ e presença mínima de albúmen. Nesse período, os frutos que atingiram cerca de $55 \%$ do seu tamanho final, eram bem globosos e avermelhados. Com 80 dias os frutos iniciaram a maturação; o avermelhamento tomou cerca de $80 \%$ da sua superficie; o embrião apresentava-se com $13 \mathrm{~mm}$ e integumentos com $15 \mathrm{~mm}$ de comprimento.

Estádio IV. Com 86 dias, os frutos, jā completamente maduros (polpa bem macia), intensificaram o aroma e a coloração; " embrião e os integumentos permaneceram com as mesmas medidas observadas ao final do Estädio III.

Os frutos do 'Tropical' atingiram ponto de coTheita comercial ('de vez'), próximo aos 78 dias da floração. Colhidos nessa época e mantidos sob ambiente de laboratório $\left(25^{\circ} \mathrm{C}\right)$, os frutos amadureceram em quatro dias, enquanto que conservados sob frigorificação, o fizeram em duas semanas. 
4.1.6.3. Produção das plantas

Assim como nos demais parâmetros bioagronômicos avaliados, a produção de frutos de 'Tropical' e 'Aurora-2', também foi afetada significativamente $(P<0,01)$ pelas épocas de poda drástica (TABELA 10).

As maiores quedas de produção foram verificadas em plantas dos tratamentos $\underline{3}$ e $\underline{4}$, decorrentes, tanto da redução da frutificação efetiva das plantas, quanto do menor peso dos frutos.

Os pesos médios dos frutos de 'Tropical' foram de: 50,9; 45,9; 45,6; e, 44,4 gramas, e de 'Aurora-2': 56,1; 52,$9 ; 45,5 ;$ e, 42,4 gramas, respectivamente aos tratamentos $\underline{1,} \underline{2}, \underline{3}$ e $\underline{4}$. Pelos dados obtidos, os frutos de 'Tropical' e 'Aurora-2', mesmo em plantas Controles, podem ser considerados de padrão médio a baixo, de vez que esses cultivares têm potencial para produção de pêssegos bem maiores.

Acredita-se que o número de frutos, mantidos nos tratamentos $\underline{1}$ e $\underline{2}$, tenha sido excessivo para as plantas, provẹcando a competição por água, nutrientes e reguladores de crescimento, e consequlentemente a redução no seu peso médio.

Nos tratamentos $\underline{3}$ e $\underline{4}$, apesar da baixa frutificação, não houve melhoria no peso médio dos frutos, fato que pode ser atribuído à própria imaturidade das plantas, pouco desenvolvidas após as podas tardias. Isto leva a 


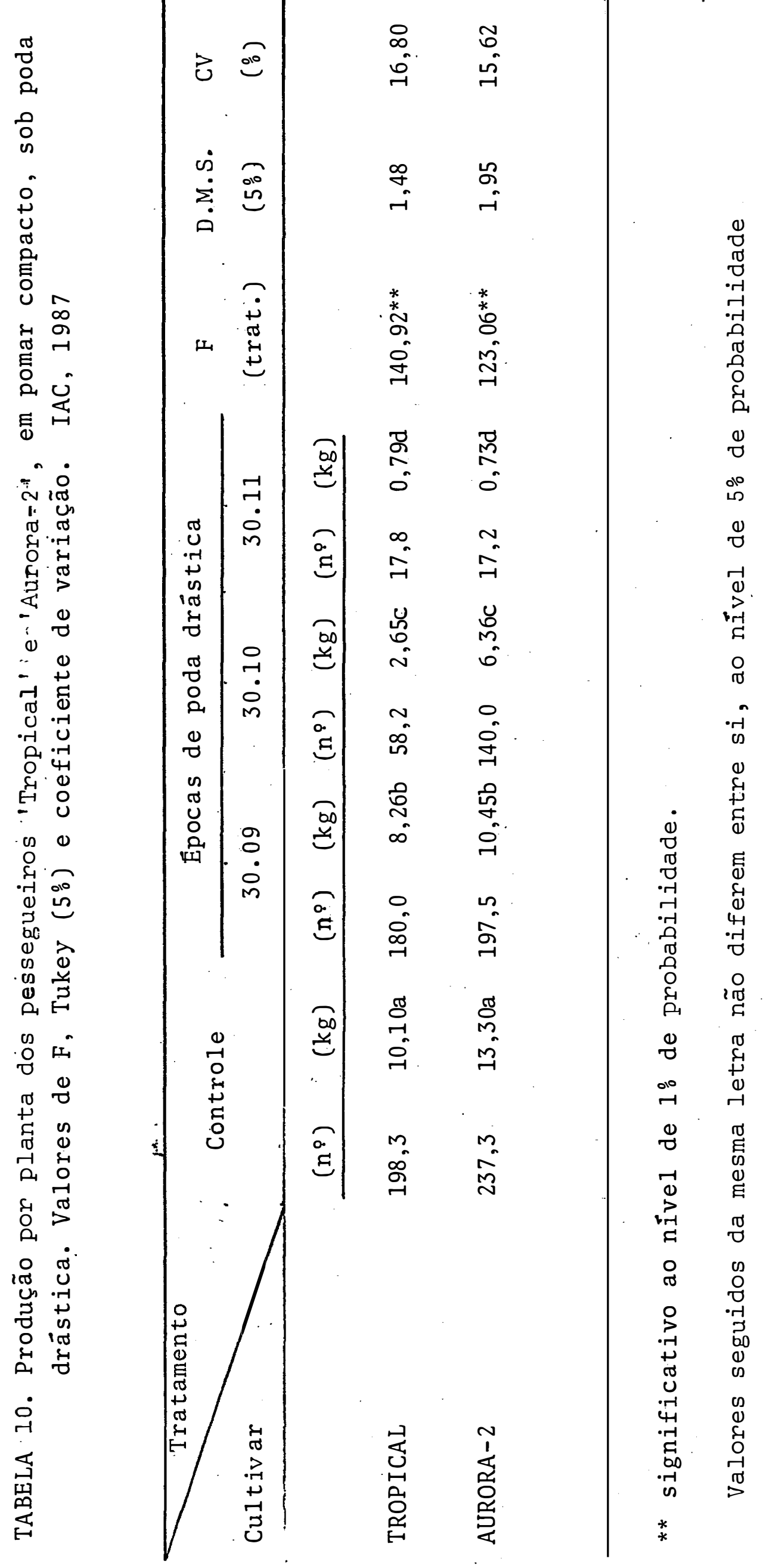


crer que pessegueiros compactos sob poda drástica possam diminuir os pesos médios dos frutos.

Essas constatações podem ser asseveradas por experimentação desenvolvida no IAC. Por exemplo, sob o espaçamento de $3,0 \mathrm{~m} \times 0,5 \mathrm{~m}$, pessegueiros precoces diversos, obtiveram-se pesos médios variando entre 40 a 70 gramas por fruto. A densidade de frutos em cultivares como: Dourado-I, Ouromel-2, Ouromel-3 e Jóia-2 ficou na faixa dos 50 a 70 por .'. planta. Os cultivares bem precoces como Maravitha e Flordaprince, nesse mesmo espaçamento, com 36,7 e 73,7 frutos por planta, atingiram peso médio de 62,0 gramas. Em espaçamento. de $3,0 \times 0,5 \times 0,5 \mathrm{~m}$ (fileira dupla), os cultivares referidos, diminuíram de 10 a $20 \%$, o peso médio dos frutos (CAMPO-DALL'ORTO, et al., 1984).

o 'Premier', em outro exemplo, cultivado no Rio Grande do Sul, em espaçamento semi-adensado (5,0m x 4,0m), sob quatro intensidades e sete épocas de poda, proporcionou frutificações de diferentes pesos médios. Assim, com intensidades de poda dos ramos de: 0; 25; 50; e, 75\%, o peso médiọ dos frutos foi de: 26,2; 30,1; 35,4; e, 39,0 gramas, respectivamente. Nessa experimentação, a maior produção média obtida foi de $22,2 \mathrm{~kg} / \mathrm{planta}$, sob intensidade de poda de 25\%. Ao se realizar a poda de 15 de junho, com intensidade de 25\%, obteve-se produção de até . 1.119 frutos, equivalente a $32,3 \mathrm{~kg} / \mathrm{planta}$. Os baixos pesos médios verificados decorreram do não raleio dos frutos. Nesse cultivar, 
quando se executa o raleio dos frutos, esses atingem pesos mêdios de cerca de 9.0. gramas (FOLTRAN, 1983).

Por último, EREZ (1.976) relata que em Israel, a nectarina 'Sundred', conduzida em espaçamento de 1,30m x 0,40m sob poda drástica, atingiu peso médio dos frutos de 47,8 gramas; a produção média das plantas correspondeu a $1,2 \mathrm{~kg}$.

Em nosso procedimento, o 'Tropical' e 'Aurora-2', nas diferentes épocas de póda drástica, atrásaram a época de maturação dos frutos (FIGURA 15). No 'Tropical', as podas mais tardias prolongaram o ciclo de crescimento dos frutos entre 10 e 15 dias. No caso de 'Aurora-2', a plena maturação dos frutos ocorreu com 15 a 25 dias de atraso.

Os resultados realçam, portanto, que ao sistema de pomar compacto de pessegueiro com poda drástica, realmente hã necessidade do cultivo de materiais bem precoces. Os pessegueiros sob esse sistema, nas condições subtropicais paulistas, com período longo para o seu desenvolvimento, devem apresentar a maturação dos frutos no final do inverno ou no início da primavera, para que se suceda a poda o mais cedo possível. 0 pessegueiro podado em época antecipada, apresenta todas as condições para se desenvolver rapidamente e flotescer :ao nono er amadurecer os frutos ao $12 \%$ mês :após a poda. Essa sequência, obtida com 'Tropical', a mais precoce seleção IAC, podada em 30 de setembro, possibilitou a 
124.

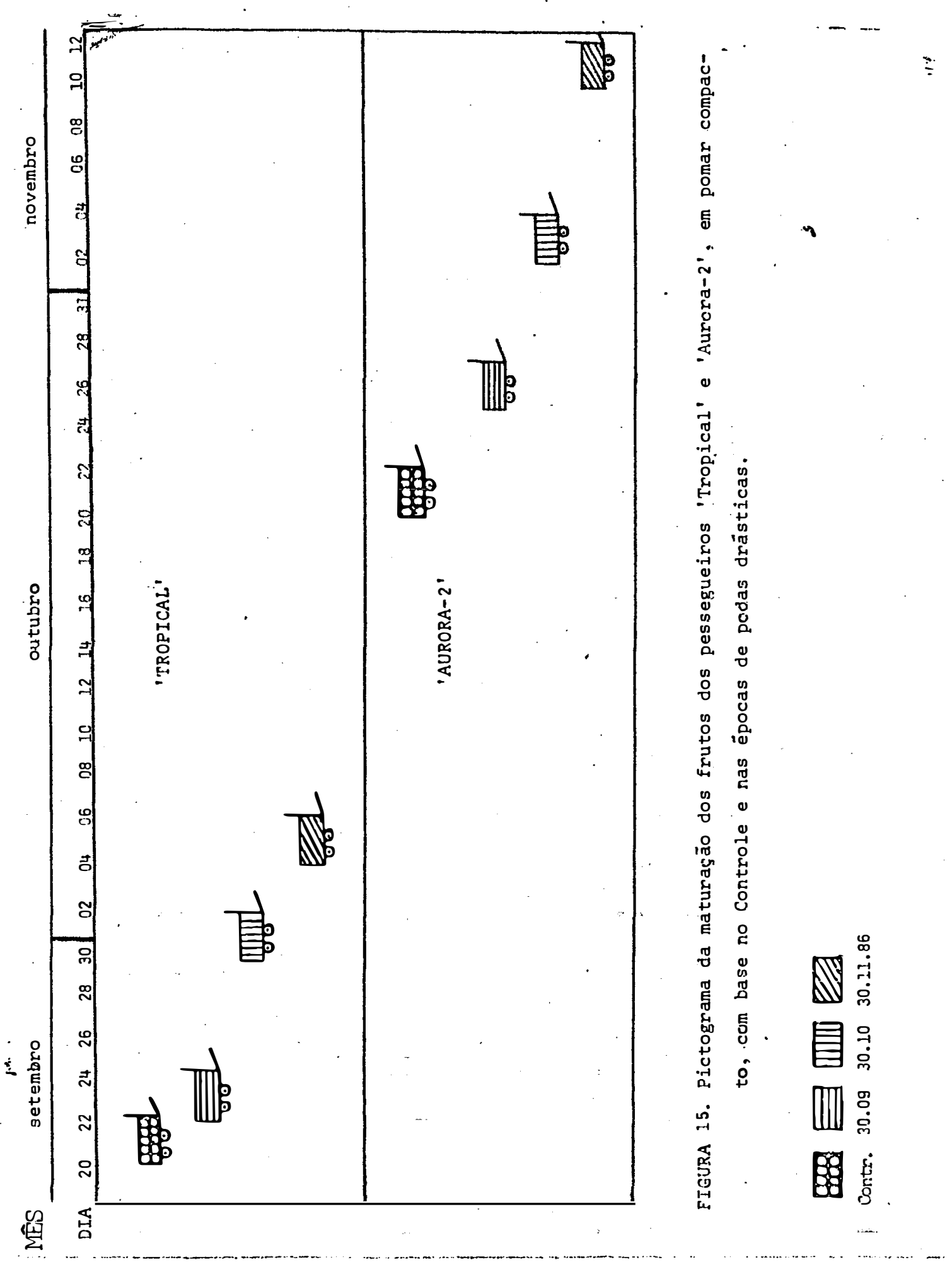


repetição do ciclo no ano subsequlente. Já o 'Aurora-2', cultivar mediano, mostrou-se inviável a esse sistema, pois, mesmo submetido à poda em 30 de setembro, apresentou o ciclo poda-maturação dos frutos de 13 meses.

Em Israel, em que existe um período também longo para o desenvolvimento vegetativo, a nectarina 'Sunred', na densidade de 19.000 plantas/ha apresentou diferenciação floral, floração e frutificação adequadas (EREZ, I976). Esse autor, aponta o fator: cultivar x condições climáticas, como o principal requisito ao sucesso da prática de condução de pessegueiros, em pomar compacto sob poda drástica.

Os resultados obtidos no presente trabalho, conforme as épocas de poda drástica adotadas, permitem estabelecer, com pequena margem de erro, o período aproximado da diferenciação floral, floração e consequente maturação dos frutos, de um determinado material, para as condições locais. - Acredita-se ainda,- que sob este sistema de condução, a época de colheita dos frutos de pessegueiros bem precoces, possa ser ainda antecipada, em um mês ou mais. Para isš́, o tratamento químico indutor de floração poderia ser realizado em fins de março ou até início de abril; ocoṛrendo a plena florada após 30-40 dias, é possível que a colheita se proceda no máximo, no início de agosto. Entretanto, ao pleno conhecimento da viabilidade fisiológica da planta, quanto a floração e frutificação precoces, há necessidade de efetuar pesquisas especificas. Haja visto, que pessegueiros em sis- 
126.

tema de pomar compacto sob poda drástica pós-colheita apresentam comportamento, de certo modo, distinto, daqueles conduzidos convencionalmente. 


\section{CONCLUSÕES}

1. Os pessegueiros 'Tropical' e 'Aurora-2', alcançaram, cerca de $70 \%$ de seu desenvolvimento nos três primeiros meses subsequlentes as podas drásticas. Suas plantas demonstraram maior ritmo de crescimento no período de outubro a fevereiro. Esses pessegueiros se desenvolveram adequadamente com a poda drástica de 30 de setembro. No final do ciclo vegetativo, o 'Tropical' e o 'Aurora-2', atingiram $\bar{x}=2,40$ e 2,4l metros de altura e com 44,3 e 38,4 nós por metro de ramo e 2,46 a 2,69 gemas/nó, respectivamente. Esses parâmetros fenológicos se apresentaram significativamente menores, com as podas realizadas em 30 de outubro e 30 de novembro. Os, pessegueiros deste ültimo tratamento não se encontraram fisiologicamente maturos, na época estipulada para quebra-de-endodormência (29 de maio).

is

2. A diferenciação floral de 'Tropical' e 'Aurora-2' foi praticamente concomitante dentro dos mesmos tratamentos de poda. 0 período fotoindutivo à organogênese floral provavelmente se iniciou em fins de dezembro. Os pessegueiros Controles diferenciaram os botões florais durante janeiro; esse período coinciadiu com o máximo crescimento vege- 
tatịyo das plantas e com a dịminuịção do fotoperíodo. Os meristemas coletados em novembro e cultivados in vitro, desenvolveram-se apenas vegetativamente. 0 mesmo não ocorreu quando foram coletados e cultivados in vitro, em dezembro, janeiro e fevereiro. Nesse período, os meristemas já induzidos à iniciação floral deram origem exclusivamente a botões florais.

Os pessegueiros provenientes das podas drāsticas de 30 de setembro, 30 de outubro e 30 de novembro, atrasaram a diferenciação floral de suas gemas; em relação aos seus Controles houve atraso de cerca de um, dois e três meses, respectivamente. Esses pessegueiros foram induzidos a diferenciação floral após um período mínimo de cinco meses de desenvolvimento. Após 30 dias da indução floral, os botões apresentavam sépalas, pétalas, estames e pistilo diferenciados. Verificou-se nos pessegueiros podados em 30 de novembro, que o(s) fator(es) indutivo(s) à transformação floral das gemas ainda estava(m) presente(s) em pleno outono (abril).

$\dot{s}$ 3. O desenvolvimento de gemas floríferas e vegetativas foi afetado. significativamente com as podas drásticas. Os pessegueiros, provenientes da poda drástica de 30 de outubro e 30 de novembro, reduziram o número de gemas floríferas e vegetativas em seus ramos; houve tendência ao aumento relativo do número de gemas vegetativas e diminuição das reprodutivas. As florações ocorreram cerca de 
25 a 40 dias após o tratamento de indução de quedra-de-endodormência das gemas. Dentre os dois cultivares pesquisados, - 'Tropical' obteve os melhores índices de floração. plantas provenientes da melhor época de poda - 30 de setembro - produziram $\bar{x}=44,3$ anteras/flor e 1.706 grãos de pólen/antera, com uma germinação in vitro de $85,3 \%$.

4. A frutificação de 'Trbpical' e 'Aurora-2' também foram afetadas significativamente com as podas drásticas. Os melhores indices de frutificações foram obtidas nos pessegueiros podados em 30 de setembro. O 'Tropical' e - ' 'Aurora-2' apresentaram uma frutificação efetiva de 33,3\% e $32,9 \%$, com cerca de 25,0 e 21,3 frutos/metro de ramo, respectivamente. o 'Tropical', assim, produziu $8,26 \mathrm{Kg}$ e 0 'Aurora-2' $10,45 \mathrm{~kg}$ de pêssegos por planta.

5. No sistema de pomar compacto, hä necessidade da utilização de cultivares bem precoces e efetuar cedo a poda diástica. Desta forma, desenvolvem rapidamente e diferenciam as gemas florais no quinto, florescem no nono e amadurecem seus frutos no $12 \%$ mês após a poda drástica, permitindo repetir o ciclo no ano seguinte. As melhores regiões para a implantação deste sistema são aquelas, de : características climáticas, em que se permite o desenvolvimento do pessegueiro o ano inteiro. 


\section{REFERẼNCIAS BIBLIOGRÂFICAS}

ALI, N. \& WESTWOOD, M.N. Nucleic acids as related to juvenility in several Pyrus species. Proceedings of the American Society for Horticultural Science, 89:123-131, 1966 .

AVIDAN, B. \& EREZ, A. A reliable actinometric method for characterizing the light regime in plant canopies. Journal American Society for Horticultural Science, ll(2): 187-191, 1986 .

AMORIM, H.V. Respiração. In: FERRI, M.G. Fisiologia Vegetal. São Paulo, EPU, Ed. da Universidade de São Paulo, 1979, v.1. p.249-277.

BAGGLIOLINI, M. \& CHELLER, H.C. Les stades repèrès dans la végétation du blé. Revue Romande D'Agriculture de Viticulture et d'Arboriculture, 3:17-28, 1954.

BANDEL, G. Desenvolvimento e diferenciação em 'plantas. Piracicaba. Escola Superior de Agricultura "Luiz de Queiroz", 1979. 159p. (apostila de curso) 
BARBOSA, W..; CAMPO-DALL'ORTO, F.A. \& OJIMA, M. Aspectos reprodutivos das fruteiras de clima temperado, objetivando o melhoramento genético. O Agronômico, Campinas, 35:15-20, 1983. BARBOSA, W.; CAMPO-DALL'ORTO, F.A. \& OJIMA, M. Cultura de embriões in vitro para melhoramento de pessegueiro precoces. Bragantia, Campinas, $\underline{44}(1): 465-472$. 1985.

BARBOSA, W.; CAMPO-DALL'ORTO, F.A. \& OJIMA, M. Relação entre precocidade de maturação e desidratação das sementes de pêssego. Pesquisa Agropecuāria Brasileira, Brasília, $\underline{19}(3)$ : 337-339, 1984 .

BARBOSA, W.; CAMPO-DALL'ORTO, F.A. \& OJIMA, M. 0 pessegueiro no sistema de pomar compacto: conjeturas, experimentação e prática. O Agronômico, Campinas, 4l(l), 1989a (prelo)

BARBOSA, W.; CAMPO-DALL'ORTO, F.A. \& OJIMA, M. Eliminação de anomalias fisiológicas de plântulas de pessegueiro in vitro. Bragantia, Campinas, 1989b. (prelo)

BARBOSA, W:; CAMPO-DALL'ORTO, F.A. \& OJIMA, M. Comportamento vegetativo e reprodutivo do pessegueiro.'Tropical'. Campinas, Instituto Agronômico, 1989e (Boletim científico ) (prelo) $\stackrel{1}{1}$

BARBOSA, W.; CAMPO-DALL'ORTO, F.A,; OJIMA, M.; SAMPAIO, V.R. \& BANDEL, G. Ecofisiologia do desenvolvimento vegetativo -e reprodutivo do pessegueiro em região subtropical. Campinas, Instituto Agronômico, 1989c (Documentos IAC, ) (prelo) 
BARBQSA, W.; CAMPO-DALL'ORTO, F.A.; OJIMA, M.; MARTINS, F.P. \& RTGITANO, O. Quebra de dormência das sementes do pêssego porta-enxerto 'Okinawa'. O Agronômico, Campinas, ' $\underline{3} 9(1)$ : 41-44, 1987a.

BARBOSA, W.; CAMPO-DALL'ORTO, F.A.; OJIMA, M.; MARTINS, F.P. \& RIGITANO, 0. Emergêncià de plântulas do pêssego porta-enxerto 'Okinawa': Influência de períodos de estratificação e de ácido giberélico. Bragantia, Campinas, $\underline{46}(2)$ : 435-44l, 1987b.

BARBOSA, W.; CAMPO-DALL'ORTO; F.A.; OJIMA, M.; CAMPOS, S.A.F. \& TOMBOLATO, A.F.C. Micropropagação vegetativa das macieiras 'Rainha' e 'Gala'. O Agronômico, Campinas, $\underline{38(1):}$ $45-47,1986 a$.

BARBOSA, W.; CAMPO-DALL'ORTO, F.A.; OJIMA, M.; CAMPOS, S.A.F. \& TOMBolato, A.F.C. Propagação vegetativa in vitro de cultivares de macieira, Bragantia, Campinas, "ㄴ5(1):143-154, 1986b. BARBOSA, W.; TOMBOLATO, A.F.C.; CAMPO-DALL'ORTO, F.A.; OJIMA, M.; RIGITANO, O. \& MARTINS, F.P. Conservação de sementes de pêssegos para produção de porta-enxertos. Campinas, $\underline{1}$ Instituto Agronômico, 1986c. 12p. (Boletim técnico; 104)

BARBOSA, W.; OJIMA, M.; CAMPO-DALLORTO, F.A.; RIGITANO, 0.; NARTINS, F.P.; CASTRO, J.L. \& SANTOS, R.R. 'Tropical': novo pêssego de coloração vermelho-intenso e bem precoce para São Paulo. In: CONGRESSO BRASILEIRO DE FRUTICULTURA, 10., Fortaleza, 1989d. Anais (prelo) 
BARGTONI, G.; LORETI, F. \& PISANI, P.L. Observazioni sulla coltivazione del pesco ad elevate densitầ dị piantagione. Rivista Ortoflorofrutticolture Italiana. '조(3):147-159, 1979. BARGIONI, G.; LORETI, F. \& PISANI, P.L. Perfomance of peach and nectarine in a high density system in Italy. . HortScience, 18(2):143-146, 1983 .

BASSOLS, M.C.M. Frutificação efetiva, germinação do pólen e número de grãos de pólen por antera em pessegueiro. Pelotas, UEPAE de Cascata, 1980. 3fls. (EMBRAPA/UEPAE de Cascata. Pesquisa em andamento, 2)

BLANCO, A. Control of shoot growth of peach an nectarine trees with paclobutrazol. Journal of Horticultural Science, $\underline{63}(2): 201-207, \quad 1988$.

BLEICHER, J. \& TANAKA, H. Doenças do pessegueiro no Estado de Santa Catarina. 2ed. Florianópolis, EMPASC, 1982. 53p. (Boletim tēcnico, 4)

BELLINI, E.; CIMATO, A. \& MARIOTTI, P. 'Six years' observations on a meadow - orchard of self-rooted nectarine in protected cup̣ture. International Simposium on peach, 1984 . (Abstracts, p.82)

BONAMY, P.A. \& DENNIS JUNIOR, F.A. Abscisic acid levels in seeds of peach. II Effects of stratification temperature. Journal of the American Society for Horticultural Science, $102(1): 26-28, \quad 1977$. 
BREVIGLIERE, N, Recherches sur la pollinisation chêz le pommier et chêz le poirier. "In: CONGRESSS POMOLOGIQUE, 89 ème. France, Societê Pomologique, 1958. p.135-143. BROWEN, H.H. \& DERICKSON, G.W. Relationship of endogenous flower bud abscisic acid to peach chilling requeriments, bloom dates, and applied gibberellic acid. HortScience, $\underline{13}(6): 694-696,1978$.

BROWN, D.S. Relation of irrigation practice to the differentiation and development of apricot flower buds. Botanical Gazette, 114:95-102, 1952.

BUBAN, T. \& FAUST, M. Flower bud induction in apple trees: internal control and differentiation. Horticultural Reviews, $\underline{4}: 174-203, \quad 1982$.

BYRNE, D.H. Mechanisms of spring freeze injury avoidance in peach. HortScience, 21:1235-1236. 1986.

CAMPINAS, Instituto Agronômico. Pêssego: In: . INST'RUÇõES AGRICOLAS PARA O ESTADO DE SÃO PAULO. 4.ed. Campinas, Instituto Agronômico, 1987. 231p. (Boletim, 200)

CAMPÖ-DALL'ORTO, F.A.; OJIMA, M.; BARBOSA, W.; TOMBOLATO, A.F.C.; RIGITANO, O. \& ALVES, S. Cultivo de seleções de pessegueiros precoces no sistema de pomar compacto com poda drástica. Pesquisa Agropecuāria Brasileira, Brasília, $\underline{19}(6): 719-727, \quad 1984 a$. 
'CAMPO-DALL'ORTO, F.A.; OJIMA, M.; BARBOSA, W.; TOMBOLATO, A.F.C.; RIGITANO, O.; ALVES, S. \& SANTOS, R.R. Pessegueiros precoces: sob ultra-adensamenta de plantio. 0 Agronômico, Campinas, 36(2):299-301, 1984b.

CHALMERS, D.J.; MITCHELL, P.D. \& van HEEK, L. Control of peach tree growth and productivity by regulated water supply, tree density, and summer pruning. Journal of the American Society for Horticultural Science, $106(3)$ : 307-317, 1981 .

CLOWES, F.A.L. Morphogenesis of the shoot apex. Oxford University Press, 1972. 16p.

COMPOSIÇÃo química dos alimentos. Revista Boa Forma, Rio de Janeiro, p.32-39, 1980.

CRANE, J.C. The role of hormones in fruit sete and development. HortScience, 4:108-11l, 1969.

COUVILLON, G.A. Leaf elementai content comparisons of ownrooted peach cultivars to the same cultivars. on several peach seedling rootstocks. Journal oficthe American Søciety for Horticultural Science, 107(4):555-558, 1982.

COUVILLON. G.A. Production and performance of inexpensive peach trees for high density peach plantings: International Simposium on peach, 1984. (Abstracts, p.71) 
COUVILLON, G.A. \& EREZ, A. A preliminary evaluation of the meadow orchard for peach production. Compact Fruit Tree, 12: 82-84, 1979 .

COUVILLON, G.A. \& EREZ, A. Rooting, surviral, and development of several peach cultivars propagated from semi-hardwood cuttings. HortScience, 15(1):41-42, 1980 .

DETIEN, L.R. Fruit fulness in peaches and its relation ship to morphology and physiology of the pollen grains. University Agricultural Experimentation Station, 1945 • 24p. (Bulletin, 257).

DIAS, D.A. \& MARTIN, G.C. Peach seed dormancy in relation to endogenous inhibitors and applied growth substances. Journal of American Society for Horticultural Science, $97(5): 651-654, \quad 1972$.

DORSEY, M.L. \& McMUNN, R.L. The development of the peach seed in relation to thinning. Proceedings of the American Society for Horticultural Science, 23:402-413, 1926.

DORSEY, M.L. \& MCMUNN, R.L. Relation of time of thinning peraches to the growth of fruit and tree. Proceedings of the American Society for Horticultural Science, 24 : $221-228, \quad 1927$.

EREZ, A. Adaptation of the peach meadow orchard system. Acta Horticulturae, 65:245-250, 1976 . 
EREZ, A. The fresh market peach meadow orchard: the mechanized and the intensive high-yield systems. Acta Horticulturae, 114:285-291, 1980 .

EREZ, A. Peach meadow orchard: two feasible syistems. HortScience: $17(2): 138-142,1982$.

EREZ, A. Dwarfing peachs by pruning and by paclobutrazol. Acta Horticulturae, 146:235-241, 1984.

EREZ, A. Improving the rooting of peach hardwood cutting under field conditions. HortScience, 19(2):245-247. 1984 .

EREZ, A. Peach meadow orchards. Acta Horticulturae, 160: 217-224, 1986 .

EREZ, A. \& YABLOWITZ; Z. Rooting of peach hardwood cuttings for the meadow orchard. Scientia Hortiaulturae. 15: $137-144,1981$.

ESAU, K. Anatomia das plantas com sementes. São Pau1o, Edgard Blücher, 1986. 293p. $\pm$

FACHINELLO, J.C.; 'KERSTEN, E. \&' MACHADO, A.A. Efeito do ácido indolbutírico no enraizamento de estacas lenhosas de pessegueiro cv. Diamante. Pesquisa Agropecuária Brasileira, Brasília, 17(2):247-252, 1982. 
FELIPPE; G.M. Fotomorfogênese. In: FERRI, M.G. Fïsiologia Vegetal, São Paulo, EPU: Editora da Universidade de São Paulo, 1_117-167, 1979.

FERRAZ, E.C. Apontamentos de Fisiologia Vegetal. Centro Acadêmico "Luiz de Queiroz", Piracicaba, 2:100-131, 1985 (Apostila de curso).

FLORY, W.S. \& THOMES, M.L. Studies of plum pollen, its apparance and germination. Journal of Agricultural Research. 67(9):337-358; 1943 .

FOLTRAN, D.E. Efeitos de intensidades e épocas de poda sobre a produção e qualidade dos frutos do pessegueiro (Prunus persica (L.) Batsch) cultivar Premier. Porto Alegre, 1983. 68p. Dissertação (Mestrado - Faculdade de Agronomia da Universidade Federal do Rio Grande do Sul). FRANCIS, C.A. Natural daylengths for photoperiod sensitive plants. Colombia, CIAT., 32p. 1972. (Technical Bulletin, 2) GOULD, H.P. 'Peach-growing. New York, The Mac̈Miląn, 1923. $426 \mathrm{p}$.

GOURLEY, J.J. \& HOWLETT, F.S. Modern fruit production. New

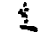
York, The MacMillan, 1949.

GOUVEIA, N.M. Estudo da diferenciação e crescimento de gemas florais de Coffea arabica L. Observações sobre a antese e maturação dos frutos. Campinas, 1984. 237p. Dissertação (Mestrado - Universidade Estadual de Campinas). 
GREULACH, У.A. Plant function and structure. New York, The MacMillan, 1973, 575p.

GRIERSON, W.; SOULE, J. \& KAWADA, K. Benefical aspects os physiological stress. Horticultural Reviews, 4:247-271, 1982 .

GUERRIEIRO, R.; LORETI, R. \& NATALI, S. Eight years of observations on a peach double-row planted orchard. Acta Horticulturae, 114:362-383, 1983.

HALL, D.0. \& RAO, K.K. Fotossintese. São Paulo, EPU: Ed. da Universidade de São Paulo, 1980. 89p.

HANSCHE, P.E. Heritability of juvenility in peach. HortScience, 21 (5):1197-1198, 1986a;

HANSCHE, P.E. Heritability of fruit quality traits in peach and nectarine breeding stocks dwarfed by the dw gene. HortScience, 21(5):1193-1195, 1986b.

*. HANSCHE, P.E.; HESSE, C.0. \& BERES, V. Estimate of genetic and environmental effects on several traits in peach. Journal of the American Society for Horticultural Science, $97(1): 9-12, \quad 1972$.

HANSCHE, P.E.; HESSE, C.O \& BEUTEL, J. Dwarf tree potential: "Just peach". American Fruit Grower, $\underline{99(8): 12-17, ~} 1979$. HARROLD, T.S. Comparative study of developing and aborting fruits of Prunus persica. 'Botanical Gazette, 96-505-520, 1935 . 
HEDRICK, U.P. . The peaches of New York. New York, J.B. Lyon, 1916. 54lp.

HUDSON. J.P. Meadow orchards. Agriculture, 78:157-160, 1971.

JACKSON, J.E. Light interception and utilization by orchard systems. Horticultural Reviews, 22:208-267, 1980.

JACKSON, D.0. \& SWEET, G.A. Flower initiation in temperate woody plants. Horticultural Abstracts, 느(1):9-25, 1972. JANICK,J. A ciência da horticultura. Rio de Janeiro, Livraria Freitas Bastos, 1968. 485p.

JOHANSEN. D.A. Plant microtechnique. New York, MacGraw Hill Book Company. 523p. 1940.

JOLY, A.B. \& LEITÃO FILHO, H.F. Botânica Econômica: as principais culturas brasileiras. São Paulo, HICITEC-EDUSP, 1979. 114p.

JONKERS. H. An international experiment on juvenility in apple. Euphytica, 20:57-59, 1971.

KNOWLTON, H.E. The relative abundance of pollen production 'By varieties of apple Proceedings of the American Society for Horticultural Science: 33:7-9, 1935.

JRAIDI, B. Contribution a l'étude de l'adaptation varitale du pécher aux conditions de milleu: anomalies florais et receptivite des ovules. Paris, 1983, 169p. These (Douteur) Université Paris. 
KELESNIKOV, V. Pollination, ovary and fruit development. In: Fruit Biology. Moscow, min publishers, 1964: p.195-208. KENDRICK, R.E. \& FLANKLAND, B. Fitocromo e crescimento vegetal. São Paulo, EPU, Ed. da Universidade de São Paulo, 1981. 76p.

LAKSO, A.N. Characterizing apple tree canopies by fisheye photography. HortScience, Iㅡ(4):404-405, 1976.

LANG, G.A.; EARLY, J.D.; MARTIN, G.C. \& DARNELL, R.L. Endo-, para-, and ecodormancy: physiological terminology and classification for dormancy research. HortScience, 22(3): $371-377, \quad 1987$.

LAVEE, S. Dormancy and bud break in a warn climate: considerations of growth regulator involvement. Acta Horticulturae, 34:225-234, 1972.

LILIEN-KIPNIS, H. \& LAVEE, S. Anatomical changes during the development of 'Ventura' peach fruits. Journal of Horticultural Science, 46:103-110, 1971.

LILLELAND, 0 . Growth study of peach fruit. Proceedings of the Amenican Society for Horticultural Science, 29: 8-13, 1932 .

LOTT, R.V. Further studies of peach fruit growth. Proceedings of the American Society for Horticultural Science, 30 : 201-203, 1933. 
LOTT, R.V. The growth rate and chemical composition of the Hilley peach from stone formation to flesh maturity. Proceedings of the American Society for Horticultural Science, 29:1-8, 1932 .

LUCKWILL, L.C. \& CHILD, R.D. The meadow orchard, a new concept of apple production based on growth regulators. Acta Horticulturae, 34:213-223, 1973.

MAGNANI, M. \& SACKS, S. Adubação e correção do solo. In: SACKS, S. e outros. A cultura do pessegueiro. Pelotas, CNPFT/EMBRAPA, 1984. 156p. (Circular técnica, 10) p. 69-82.

MAGALHÄES, A.C.N. Fotossíntese. In: FERRI, M.G., Fisiologia Vegetal. São Paulo, EPU: Editora da Universidade de - São Paulo, l1:117-167, 1979.

MARENAUD, C. \& SAUNIER, R. Action des vírus de type ILAR sur le pollen de l'espècie Prunus persica. Annual Amélionation Plantes, 24(2):169-184, 1974 .

MARTINEZ-TELLEZ, J.J. Contribution à l'étude de la biologie floprale et de la fécundation des Prunus notament chez. le pecher ( $P$. persica L. 'Batsch). Bordeaux, 1981. 156p. Tèse (Docteur - Université Bordeaux II). 
MARINI, R.P. Growth and cropping of. 'Redhaven' peach trees following foliar aplications of flur-primidol and paclobutrazol.' Journal of the American Society ' for' Horticultural Science. III(6):849-853, 1986.

MARINI, R. \& WEFELMEYER, E.L. Growth of peach seedlings affected by paclobutrazol and flurprimidol: HortScience, $20(3): 526, \quad 1985$ (Abstracts).

MEDEIROS, A.R.M. Efeito da temperatura controlada na germinação dos grãos de pólen e crescimento do tubo polínico em pessegueiro (Prunus persica L. Batsch). In: CONGRESSO BRASILEIRO DE FRUTICULTURA, 5., Pelotas, 1979. Anais. v.2 P. 407-416.

MEDINA, D.M. \& CONAGIN, C.H.T.M. Técnica citológica. Campinas, Instituto Agronômico. 1964. 108p... (Publicação n 2610).

MELLENTHIN, W.N.; WANG, C.Y \& WANG, S.Y. Influence of temp on pollen tube growth and initial fruit development in d'Anjou pear. Hortscience, $\underline{7}(6): 557-559,1972$.

MENTEN, J.O.; LORDELLO, L.G.; CAMPO-DALL'ORTO, F.A.; OJIMA, M. \& RIGITANO, 0. Resistência varietal do pessegueiro (Prunus persica Batsch) aos nematóides $M$. incognita e M. arenaria. In: REUNIÃO DE NEMATOLOGIA, 2., Piracicaba, 1976. Anais. Piracicaba, Sociedade Brasileira de Nematologia, 1977. P. $165-174$. 
METIVIER, J.R. Citocininas. In: FERRI, G.C. Fisiologia Vegetall.: São Paulo, EPU, Ed. da Universidade de São Paulo, 1979. v. 2, p.93-127.

MILLER, S.S. Sumner pruning affects fruit quality and light penetration in young peach trees. HortScience, 22(3): $390-393,1987$.

MONET, R. Le pêcher: genetique et physiologie. Paris, INRA et Masson, 1983. 133p.

MONET, R. \& BASTARD, Y. Initiation florale et phenomènes de lie dormance chez le pêcher. Comptes Rendus Hebdomadaires des.Acadēmie Séances de l'Academie des Sciences, Paris, 268:193:1-1933, 1969 .

MONET, R. \& BASTARD, Y. Les mecanismes de la floraison chez le pêcher. Bulletim Technical Information, 248:173-176, 1970 .

MONET, R. \& BASTARD, Y. Morphologie végétale, morfogenèse et croissance des ébauches florales chez le pêcher (Prunus persica L. Batsch). Comptes Rendus Hebdomadaires des Séances de 1'Academie des Sciences, Paris, 266:1845-1848,

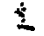
1968 .

MURASHIGE, T. \& SKOOG, F. A revised medium for rapid growth and bioassays tobaco tissue cultures. Physiologie Plantarum, $15: 473-497,1962$. 
NITSCH, J. Photoperiodism in wood plants. Proceedings of the American Society for Horticultural Scienne. 70 : $526-544, \quad 1957$

OJIMA, M.; CAMPO-DALL'ORTO, F.A.; BARBOSA, W.; MARTINS. F.P.; SANTOS, R.R.: \& RIGITANO, O. 'Aurora-1' e 'Aurora-2' novos cultivares de pêssegos doces, de polpa amarela e firme. In: CONGRESSO BRASILEIRO DE FRUTICULTURA, . 10., Fortaleza, 1989. Anais (prelo)

OJIMA, M.; CAMPO-DALL'ORTO, $\dot{F} . A . \&$ RIGITANO, O. Mudas precoces de pessegueiro. Campinas, Instituto .... Ağronômico, 1977. 13p. (Boletim técnico, 45)

OJIMA, M.; CAMPO-DALL'ORTO, F.A.; RIGITANO, 0.; TOMBOLATO, A.F.C. \& BARBOSA, W. Melhoramento da nectarina em São Paulo. I. Cruzamento de 1970: seleção nas gerações $F_{1}$ e F2. Bragantia, Campinas, 42:1-14, 1983.

PEDRO JUNIOR, M.J.; ORTOLANI, A.A.; RIGITANO; O.; ALFONSI, R.R.; PINTO, H.S. \& BRUNINI, 0. Estimativa de horas de frio abaixo de 7 e de $13^{\circ} \mathrm{C}$ para regionalização da Fruticultura de pinas, 38:123-130, 1979.

PIMENTEL-GOMES, F. A estatística moderna na pesquisa agropecuâria. Piracicaba, POTAFOS, 160p. 1984.

PIRINGER, A.A. \& DOWNS, R.J. Response of apple and peache trees to various photoperiods. Proceedings to the American Society for Horticultural Science, 73:9-13, 1958. 
PIZZA JUNIOR, C.T. \& BRAGA, T.G. A cultura do pessegueiro, Campinas, CATI, 1974. 144p. (Boletim técnico, 29)

POWELL, L.E. \& PRATTI, C. Growth promoting substances in the developing fruit of peach (Prunus persica L. Batsch). Journal of Horticultural Science, 니:331-348, 1966.

RAGLAND, C.H. The development of the peach fruit with special reference to split pit and gumming. Proceedings of the American Society for Horticultural Science, 31:1-21, 1934 .

REMY, P. Contribuition à l'étude du pollen des arbres fruitiers à noyay, genre Prunus. Annales Amelioration Plantes. $3: 351-388, \quad 1953$.

RIGITANO, 0. A cultura do pessegueieiro. Rio de Janeiro. Ministério da Agricultura, Serviço de Docümentaçãors 1945. $114 \mathrm{p}$.

RIGITANO, O.; OJIMA, M. \& CAMPO-DALL'ORTO, F.A. Comportamento de novas seleções de pếssegos introduzidas da Flörida. Campinas, Instituto Agronômico, 1975. 12p.' (Circulaip, 46 )

SACHS, S. e outros. A cultura do pessegueiro. Pelotas, CNPFT/EMBRAPA, 1984. 156p. (Circular tẻcnica, 10)

SALISBURY, F.B. Photoperiodism. Horticultural Reviews, $\underline{4}: 66-105,1982$. 
SÃo PAULO, Secretaria da Agricultura e Abastecimento: Progrna Paulissta de Pruticultura de Clima Temperado, São Pau1o, 1983. 9.6.

SANSAVINI, S. Impianti e allevamento del pesco: analisi e prospecttive delle tendenze in atto. Frutticoltura Bologna, $43(2): 9-38,1981$.

SCORZA, R. In vitro flowering. Horticultural Riviews, 4 : $106-127,1982$.

SEARLE, N.E. Physiology of flowering. Annual Riview Plant Physiology, 16-97, 1965.

SERVIÇO NACIONAL DE PESQUISAS AGRONÔMICAS. Comissão de solos. Levantamento de reconhecimento dos solos do Estado de São Paulo. Rio de Janeiro, Ministério da Agricultura, 1960, 634p. (Boletim, 12)

SHULMAN, Y.; NIR, G.; FANBERSTEIN, L. \& LAVEE, S. The effect of cianamide on the release from dormancy of grapevine buds. 'Scientia Horticulturae, 19:97-104, 1983. TOMBESI, A. Tipiche variazione dell struttura dell'apice di pesco della estadio indiferrenziato a quelo riproduttivo. Rivista Ortoflorofiutticoltura Italiana, 49:401-421. 1965. TOMBESI, A. \& BELLEGGIA, S. L'influenza dell'intensità di illuminazione della chioma sulla differenziazione delle gemme a fiore e sulla qualità delle pesche. cv. 'Flavorcrest". Rivista Ortoflorofrutticoltura Italiana: 70:287-306, 1986. 
148.

TOMBOLATO, A.F.C. Etude de I'influence de facteurs agissant sur dêveloppement de l'embryon du pềcher (Prunus persica L. Batsch) "in situ" et "in vitro" jusqu'a I'obtention de la jeune plante. Bordeaux. Thèse (Douteur - Universidade de Bordeaux II) 1984. 190p.

TUKEY, M.B. Growth of peach embryo in relation to growth of fruit and season of ripening Proceedings of the American Society for Horticultural Science, 30:209-218, 1933.

VALADARES, J.; LEPSCH, I.F. \& KUPPER, A. Levantamento pedalógico detalhado da Estação Experimental de Jundiaí, SP. Bragantia, Campinas 30:337-386, 1971.

WARRINER, C.L.; JOHNSON, J.L. \& SMITH, M.V. Comparation of the initiation and development of "Redhaven" peach flowers in standard and meadow orchard trees. Journal of the American Society for Horticultural Science, 110(3):379-383, 1985 .

WERNER, D.J.; MOWREY, B.D. \& CHAPARRO, J.X. Variability in flower bud number among peach and nectarine cultivars. HoritScience, $\underline{23}(3): 578-580$. 1988 .

WESTWOOD, M.N. Temperate-zone Pomology, San Francisco, W.H. Freeman and Company, 1978. 428p.

WILLIAMS, R.R. Factors affecting pollination in fruit trees. In: LUCKWILL, L.C. \& CUTTING, C.V. eds. Physiology of tree crops. London, Academic Press, 1970. 193-207. ZIMMERMAN, R.H. Juvenility and flowering in wood plants: a review. HortScience, $\underline{7}(5) \cdot 447-455,1972$. 
APENDICE 1 . Valores mensais de temperatura média, média das máximas, média das mínimas, precipitaçāo pluviométrica e insolação, registrados na Estaçāo Experimental de Jundiaí, SP. $\left(23^{\circ} 08^{\prime} S\right)$, no ano de 1986.

\begin{tabular}{|c|c|c|c|c|c|}
\hline \multirow{2}{*}{ Mês } & \multicolumn{3}{|c|}{ Temperatura do ar $\left({ }^{\circ} \mathrm{C}\right)$} & \multirow{2}{*}{$\begin{array}{l}\text { Precipitaçāo } \\
\text { p] uviométrica } \\
\text { (mm) }\end{array}$} & \multirow{2}{*}{$\begin{array}{c}\text { Insolaçāo } \\
\text { (h) }\end{array}$} \\
\hline & Média & Māxima & Mínima & & \\
\hline JANE I RO & 24,4 & 30,7 & 18,1 & 136,7 & - \\
\hline FEVERE IRO & 23,9 & 29,2 & 18,6 & 198,0 & - \\
\hline MARÇO & 25,3 & 33,4 & 17,2 & 216,7 & - \\
\hline ABRII & $2 z, 0$ & 28,0 & 16,0 & 74,5 & - \\
\hline MAIO & 20,3 & 26,1 & 14,6 & 114,0 & - \\
\hline JUNHO & 17,5 & 24,8 & 10,2 & 4,5 & - \\
\hline JULHO & 16,5 & 23,2 & 9,9 & 38,7 & - \\
\hline AGOSTO & 18,7 & 24,9 & 12,5 & 171,7 & 198,9 \\
\hline SETEMBRO & 19,7 & 26,0 & 13,2 & 35,5 & 221,0 \\
\hline OUTUBRO & 20,5 & 27,0 & 14,0 & 72,8 & 271,0 \\
\hline NOVEMERO & 22,7 & 29,1 & 16,4 & 224,2 & 202,7 \\
\hline DEZEMBRO & 22,9 & 27,9 & 17,9 & 346,2 & 93.4 \\
\hline ANUAL & 21,2 & 27,5 & 14,9 & $1.629,5$ & - \\
\hline
\end{tabular}

Fonte: Seção de Climatologia Agrícola - Instituto Agronômico (IAC). 
APENDICE 2.Valores mensais de temperatura média, média das māximas, média das mínimas, precipitação pluviométrica e insolação, registrados na Estação Experimental de Jundiaí, SP. $\left(23^{\circ} 08^{\prime} S\right)$, no ano de 1987

\begin{tabular}{|c|c|c|c|c|c|}
\hline \multirow{2}{*}{ Mês } & \multicolumn{3}{|c|}{ Temperatura do $\operatorname{ar}\left({ }^{\circ} \mathrm{C}\right)$} & \multirow{2}{*}{$\begin{array}{l}\text { Precipitação } \\
\text { pluviométrica } \\
\text { mm }\end{array}$} & \multirow{2}{*}{$\begin{array}{c}\text { Insolação } \\
\text { (h) }\end{array}$} \\
\hline & Média & Māxima & Mínima & & \\
\hline JANEIRO & 24,2 & 29,7 & 18,4 & 369,8 & 192,5 \\
\hline FEVEREIRO & 23,7 & 29,6 & 17,8 & 211,3 & 169,3 \\
\hline MARÇO & 22,9 & 29,6 & 16,3 & 141,6 & 250,3 \\
\hline ABRIL & 22,4 & 28,0 & 16,8 & 154,8 & 202,4 \\
\hline MAIO & 18,5 & 23,5 & 13,8 & 254,0 & 153,1 \\
\hline JUNHO & 16,5 & 23,1 & 10,5 & 112,0 & 285,2 \\
\hline JULHO & 19,1 & 26,2 & 12,0 & 13,6 & 258,9 \\
\hline AGOSTO & 17,5 & 25,3 & 9,8 & 20,2 & 242,6 \\
\hline SETEMBRO & 18,6 & 24,8 & 12,8 & 98,5 & 158,6 \\
\hline OUTUBRO & 21,8 & 28,1 & 15,5 & 66,0 & 273,8 \\
\hline NOVEMBRO & 22,7 & 29,8 & 15,7 & 160,2 & 253,6 \\
\hline DEZEMBRO & 23,5 & 29,4 & 17,6 & 245,3 & 228,6 \\
\hline ANUAL & 21,0 & 27,3 & 14,8 & $1.847,3$ & 222,4 \\
\hline
\end{tabular}

Fonte: Seção de Climatologia Agrícola - Instituto Agronômico (IAC) 
151.

APENDICE 3. Fenologia dos pessegueiros 'Tropical' e 'Aurora-2' (controles) desenvolvidos em pomar compacto, sem poda drástica. Seção de Fruticultura de Climã Temperadc - IAC - 1987.

\begin{tabular}{|c|c|c|}
\hline DATA & 'TROPICAL' & 'AURORA-2' \\
\hline 30.09 .86 & Plantas em plena vegetaçāo & Plantas en plena vegetação \\
\hline 30.10 .86 & Plentas emi plena vegetaçāo & Plantas en plena vegetação \\
\hline 27.11 .86 & Copa com enfolhamento médio & Copa bastante enfolizada e frondosa \\
\hline 30.12 .86 & $\begin{array}{l}\text { Famos com crescimento mais lento; gemas en } \\
\text { desenvolvimento }\end{array}$ & $\begin{array}{l}\text { Ramos en pleno crescimento; geras en desenvolvi- } \\
\text { mento }\end{array}$ \\
\hline $29.01 .8 ?$ & $\begin{array}{l}\text { Ramos de produção com pouco crescimento vi- } \\
\text { sível; genas ben formadas }\end{array}$ & $\begin{array}{l}\text { Ramos en crescimento lento e gemas en desenvol- } \\
\text { vimento }\end{array}$ \\
\hline 24.02 .87 & Ranos com crescimento lento & Ramos com crescimento lento \\
\hline 26.03 .87 & $\begin{array}{l}\text { Plantas om crescimento lateral lento e api- } \\
\text { cal normal }\end{array}$ & Plantas com crescinento en todos os ramos \\
\hline 30.04 .87 & $\begin{array}{l}\text { Plantas con desenvolvinento vegetativo para- } \\
\text { lisado }\end{array}$ & $\begin{array}{l}\text { Plantas con crescinento lateral lento e apical. } \\
\text { nomal }\end{array}$ \\
\hline 29.05 .87 & $\begin{array}{l}\text { Ramos comrcrescimento paralicado; realização } \\
\text { do trazamento de quebra-de-endodonnència }\end{array}$ & $\begin{array}{l}\text { Ramos con crescimento paralisado; 'realizaçāo } \\
\text { do tratamento de quebra-de-endodorméncia }\end{array}$ \\
\hline 30.06 .87 & $\begin{array}{l}\text { Prebomināncia de botōes florais en estádios } \\
\text { "E" e "F" }\end{array}$ & $\begin{array}{l}\text { Predoninância de botōes florais em estádios "D" e } \\
\text { "E" }\end{array}$ \\
\hline 10.07 .87 & $\begin{array}{l}\text { Final de floração; gemas vegetativas en bro } \\
\text { tação }\end{array}$ & Plena floração; gemas vegetativas sen trotação \\
\hline 28.08 .87 & Frutinhos en estádio II, posto de ensacamento & Excelente frutificaçāo, frutinhos eni estádio I \\
\hline 23.09 .87 & Final de colheita dos furtos & Frutos en crescimento, - estádio III \\
\hline 26.10 .87 & $\dot{x} \quad--$ & Início de maturação dos frutos \\
\hline 03.11 .87 & $-\cdots$ & Final de colheita dos frutos \\
\hline
\end{tabular}


APENDICE 4. Fenologia dos pessegueiros 'Tropical' e 'Aurora-2', desenvolvidos em pomar compacto sob poda drästica de 30.09.86. Seção de Fruticultura de Clima Temperado - IAC - 1987.

\begin{tabular}{|c|c|c|c|}
\hline DATA & 'TROPICAL' & 'AURORA- 2 ' & $\begin{array}{l}\text { DIAS } \\
\text { DA } \\
\text { PODA }\end{array}$ \\
\hline 30.09 .86 & Reälização da poda drástica' & Realização da poda drástica & $\cdots$ \\
\hline 10.10 .86 & Início de brntação nos trancos decepados & Início de brotação nos troncos decepados & 10 \\
\hline 30.10 .86 & Erotos com $\bar{x}=30$ centimetros de altura & Erotos com $\bar{x}=40$ centínetros de altura & 30 \\
\hline 14.11 .86 & Intensa brotação de ramos secundārios & Intensa brotação de ramos secundārios & 45 \\
\hline 27.11 .86 & $\begin{array}{l}\text { Crescimento acelerado; altura das plantas } \\
\bar{x}=90 \mathrm{~cm} .\end{array}$ & $\begin{array}{l}\text { Crescimento acelerado e vigoroso; altura } \\
\text { das plantas } \bar{x}=1,10 \mathrm{~m} \text {. }\end{array}$ & 59 \\
\hline 30.12 .86 & $\begin{array}{l}\text { Elongação räpida dos ramos cerrmais; altu- } \\
\text { tura das plantas } \bar{x}=1 ., 80 \mathrm{~m} \text {. }\end{array}$ & $\begin{array}{l}\text { Ramificação abundante e vigorosa; altuma } \\
\bar{x}=2,00 \mathrm{~m} \text {. }\end{array}$ & 91 \\
\hline 28.01 .87 & $\begin{array}{l}\text { Genas beri desenvolvidas en ranos } \\
\text { velhos }\end{array}$ & $\begin{array}{l}\text { Gerras en desenvolvimento nos ramos mairs } \\
\text { velhos }\end{array}$ & 221 \\
\hline 24.02 .87 & Crescimento vegetativo mais lento & Crescimento vegetativo mais lento & 148 \\
\hline 26.03 .87 & Ramos laterais ser: arescinento vegetativo & Ranos laterais e apicais en crescimento & 178 \\
\hline 30.04 .87 & Ramos laterais e centrais paralisados & Ramos ben distribuidos e en vegetação & 213 \\
\hline 29.05 .87 & $\begin{array}{l}\text { Realização do tratamento de quebra-de-endo- } \\
\text { doméria }\end{array}$ & $\begin{array}{l}\text { Realização do tratamento de quebra-de-en- } \\
\text { dodorméncia }\end{array}$ & 242 \\
\hline 30.06 .87 & $\begin{array}{l}\text { Gemas floriferas nos estádios "D" e "F"; } \\
\text { gemas vegetativas en início de brotação }\end{array}$ & $\begin{array}{l}\text { Gemas floríferas nos estádios "C" e "D"; } \\
\text { gemas vegetativas paralisadas }\end{array}$ & 274 \\
\hline 06.07 .87 & Plena floração e vegetação & $\begin{array}{l}\text { Terço inferior da planta en flonação; } \\
\text { emissão lenta de brotos }\end{array}$ & 280 \\
\hline 28.08 .87 & $\begin{array}{l}\text { Excelente frutificação efetiva; frutos en } \\
\text { estádio II . }\end{array}$ & $\begin{array}{l}\text { Excelente frutificação efetiva; frutos } \\
\text { entre estadio I e II }\end{array}$ & 333 \\
\hline 23.09 .87 & Pico de naturação dos frutos & Frutinhos en crescimento; estädio III & 359 \\
\hline 26. 10.87 & - & Pico de maturação dos frutos & 392 \\
\hline
\end{tabular}


APÊNDICE 5. Fenologia dos pessegueiros 'Tropical' e 'Aurora-2', desenvolvimento em pomar compacto sob poda drástica de 30.10.86. Seção de Fruticultura de Clima Temperado IAC - 1987

\begin{tabular}{|c|c|c|c|}
\hline DATA & ''TROPICAL' & 'AURORA-2' & ${ }_{\mathrm{DA}}^{\mathrm{DIAS}}$ \\
\hline 30.10 .86 & Realizaçāo da poda drástica & Realização da poda drástica & 0 \\
\hline 05.11 .86 & Início de brotação & Início de brotação & 6 \\
\hline 27.11 .86 & Brotos corn $\bar{x}=20$ centinetros de altura & Brotos com $\bar{x}=30$ centímetros de altura & 29 \\
\hline 30.12 .86 & $\begin{array}{l}\text { Gemas pouco desenvolvidas; plantas com } \\
\bar{x}=70 \text { on de altura }\end{array}$ & $\begin{array}{l}\text { Gemas pouco desenvolvidas; plantas com } \\
\bar{x}=90 \text { on de altura }\end{array}$ & 61 \\
\hline 28.01 .87 & $\begin{array}{l}\text { Inicio do crescinento das genas; plan- } \\
\text { tas com } \bar{x}=1,10 \text { m de altura }\end{array}$ & $\begin{array}{l}\text { Inicio do crescimento das gemas; plan- } \\
\text { tas com } \bar{x}=1,40 \mathrm{~m} \text { de altura }\end{array}$ & 90 \\
\hline 24.02 .87 & Gemas en desenvolvimento & Gemas em desenvolvimento & 117 \\
\hline 26.03 .87 & $\begin{array}{l}\text { Alguns ramos laterais paralisados e con } \\
\text { gemas ber desenvolvidas }\end{array}$ & Ramos e gemas en desenvolvimento & 147 \\
\hline 30.04 .87 & $\begin{array}{l}\text { Cerca de } 80 \% \text { dos ramos corn crescimento } \\
\text { paralisado }\end{array}$ & $\begin{array}{l}\text { Cerca de } 908 \text { dos namos en crescimento } \\
\text { lento }\end{array}$ & 182 \\
\hline 29.05 .87 & $\begin{array}{l}\text { Realização do tratamento de quebra-de- } \\
\text {-endodomência }\end{array}$ & $\begin{array}{l}\text { Realização do tratamento de quebra-de-en- } \\
\text { dodormência }\end{array}$ & 211 \\
\hline 30.06 .87 & $\begin{array}{l}\text { Gemas floríferas nos estádios "C" e "D" } \\
\text { e vegetativas en brotação }\end{array}$ & $\begin{array}{l}\text { Gemas floriferas nos estādios "B" e "C" } \\
\text { e vegetativas san brotação }\end{array}$ & 243 \\
\hline 10.07 .87 & $\begin{array}{l}\text { Plena floração das plantas; falhas de } \\
\text { flores nos ramos }\end{array}$ & $\begin{array}{l}\text { Gemas floriferas en estādios "C" e } \\
\text { e vegeta:ivas com brotação lenta }\end{array}$ & 253 \\
\hline 23.08 .87 & $\begin{array}{l}\text { Eruțificação efetiva irregular com fru- } \\
\text { toșabortivos }\end{array}$ & Frutificação efetiva muito baixa & $30 ?$ \\
\hline 03.10 .87 & Pico de maturação dos frutos & $\begin{array}{l}\text { Frutinhos en crescimento } \\
\text { Pico de maturação dos frutos }\end{array}$ & $\begin{array}{l}336 \\
369\end{array}$ \\
\hline
\end{tabular}


APÉNDICE E. Fenologia dos pessegueiros 'Tropical' e 'Aurora-2', desenvolvidos em pomar compacto, sob poda drástica de 30.11.86. Seção de Fruticultura de Clima Temperado - IAC 1987

\begin{tabular}{lcc}
\hline DATA 'TROPICAL' 'AURORA-2' & $\begin{array}{c}\text { DISS } \\
\text { DA } \\
\text { PODA }\end{array}$ \\
\hline
\end{tabular}

30.11.86 Realização da joda drästica

10.12.86 Poucas genas brotadas

30.12.86 Brotos com $\bar{x}=20$ centínetros de altura

28.01.87 Genas pequenas; plantas com $\bar{x}=70 \mathrm{~cm}$ de altura

24.02.87 Geras atrasadas; plantas com $\bar{x}=1,10 \mathrm{~m}$ de altura

26.03.87 Início do crescinento das gemas; mitos ramos juvenis

30.04.87 Cerca de $80 \%$ dos ramos en desenvolvimento lento

29.05.87 Realização do tratemento de quebra-de-en- docionmencia

30.06.87 Poucas gemas florifenas nos ramos

10.07.87 Início de brotaçāo; poucas flores

28.08.87 Poucos frutos; plantas deficientes

05.10.87 Maturiação dos frutos

11.11 .87
Realização da poda đrästica

Poucas brotaçōes iniciais

Brotos com $\bar{x}=30$ centínetros de altura

Gemas pequenas; plantas com $\bar{x}=80$ cाi de altuma

Genlas bem atrasadas; plantas com $\bar{x}=1,30 \mathrm{~m}$ de altura

Ramos com aspecto ber: juvenil; gemas pequenas

Cerca de $100 \%$ dos ramos en desenvolvimento lento

Realização do tratamento de quebra-de-endodormència

Poucas gemas floriferas nos ramos

Início de brotação, floração baixa

222

Poucos frutos; plantas deficientes

Frutos ainda pequenos 309

Maturação dos frutos

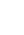


